Vitor dos Santos Henriques

\title{
DEVERES E RESPONSABILIDADES DOS AUDITORES INDEPENDENTES NAS OPERAÇÕES DE INCORPORAÇÃO ENTRE COMPANHIAS
}

\author{
DISSERTAÇÃO DE MESTRADO
}

Orientadora: Profa. Dra. Priscila Maria Pereira Corrêa da Fonseca

Faculdade de Direito da Universidade de São Paulo

São Paulo

2013 
Vitor dos Santos Henriques

\title{
DEVERES E RESPONSABILIDADES DOS AUDITORES INDEPENDENTES NAS OPERAÇÕES DE INCORPORAÇÃO ENTRE COMPANHIAS
}

\begin{abstract}
Dissertação para a obtenção do título de Mestre em Direito Comercial no Curso de Pós-Graduação strictu sensu da Faculdade de Direito da Universidade de São Paulo.
\end{abstract}

Orientadora: Profa. Dra. Priscila Maria Pereira Corrêa da Fonseca

Faculdade de Direito da Universidade de São Paulo

Departamento de Direito Comercial

São Paulo 
Nome: Vitor dos Santos Henriques

Título: Deveres e Responsabilidades dos Auditores Independentes nas Operações de Incorporação entre Companhias

Dissertação para a obtenção do título de Mestre em Direito Comercial no Curso de Pós-Graduação strictu sensu da Faculdade de Direito da Universidade de São Paulo.

Aprovado em:

Banca Examinadora:

Prof.(a)

Instituição:

Julgamento:

Assinatura:

Prof.(a)

Instituição:

Julgamento:

Assinatura:

Prof.(a)

Instituição:

Julgamento:

Assinatura: 


\section{AGRADECIMENTOS}

A Deus, por me fornecer todos os instrumentos necessários ao plantio do meu destino.

À Professora Priscila Maria Pereira Corrêa da Fonseca, pelo admirável exemplo como profissional do Direito, pela paciência e confiança em mim depositada.

Aos Professores José Alexandre Tavares Guerreiro e Rachel Sztajn pelos valiosos conselhos e sugestões que recebi em minha banca de qualificação.

Sem citar nomes para não cometer injustiças, aos meus colegas de trabalho, pela experiência e pela maturidade profissional que me ajudaram a encarar esse desafio.

Aos meus pais, Luiz Otavio Assis Henriques e Ligia Betti dos Santos Henriques, pelo amor e apoio incondicionais e por sempre me lembrarem de quem eu sou e do que sou capaz.

Ao meu irmão, Rubens Luiz dos Santos Henriques, por todos os ensinamentos profissionais e de vida que a nossa convivência conjunta nos proporciona.

À minha noiva Maria Eduarda Leitão Canabarro, pelo apoio, auxílio e paciência em meio a tantos dias e noites de estudo. 


\section{RESUMO}

O presente trabalho tem como objetivo estudar a atuação dos auditores independentes no contexto de uma operação de incorporação entre companhias abertas. Para tanto, abordaram-se os aspectos jurídicos e contábeis relevantes das operações de incorporação e, em seguida, procurou-se definir os deveres gerais e específicos aplicáveis aos auditores independentes e a responsabilidade civil em face das principais atividades desenvolvidas por tais agentes em operações dessa natureza, quais sejam, as atividades de auditoria das demonstrações financeiras e de avaliação da companhia incorporada.

Palavras-chave: Incorporação - Auditor Independente - Auditoria - Avaliação - Lei das S.A. - Responsabilidade 


\begin{abstract}
The present work aims to study the performance of the independent auditors in the context of a merger of a publicly held company into another. For such purposes, we addressed the relevant legal and accounting aspects of the merger transactions and then sought to define the general and specific duties applicable to independent auditors and the liability in view of the main activities undertaken by them in transactions of this nature, which are the activities of auditing of financial statements and the valuation of the merged company.
\end{abstract}

Keywords: Merger - Independent Auditors - Audit - Valuation - Corporations Law Liability 


\section{SUMÁRIO}

1. INTRODUÇÃO 1

2. DAS INCORPORAÇÕES ENTRE COMPANHIAS. 4

2.1. Conceito de incorporação 4

2.2. Fases e procedimentos 7

2.3. Das incorporações envolvendo companhias controladas ou sob controle comum .... 16

2.3.1. Especificidades jurídicas e contábeis 16

2.3.2. Âmbito de aplicação e escopo do artigo 264 da Lei das S.A. 24

\section{ESCOPO, ÂMBITO DE ATUAÇÃO E FUNÇÃO DAS ATIVIDADES} DESENVOLVIDAS PELOS AUDITORES INDEPENDENTES 28

3.1. Da relação jurídica entre os auditores independentes e as companhias .28

3.2. Escopo dos trabalhos e âmbito de atuação dos auditores independentes 29

3.3. Funções dos trabalhos desenvolvidos pelos auditores independentes 33

4. DA ATUAÇÃO DOS AUDITORES INDEPENDENTES NAS OPERAÇÕES DE INCORPORAÇÃO 35

4.1. Deveres gerais e pressupostos de atuação dos auditores independentes 35

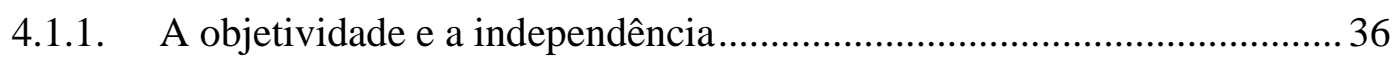

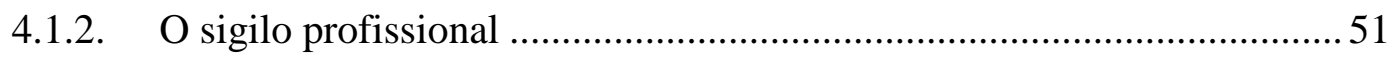

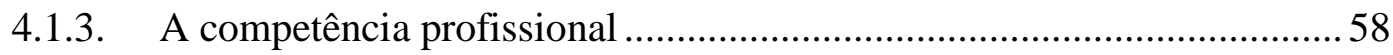

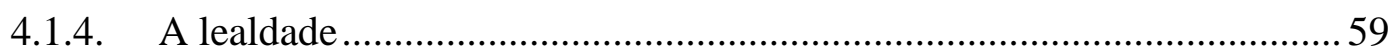

4.2. Dos papéis dos auditores independentes nas operações de incorporação ................... 61

4.2.1. A análise das demonstrações financeiras e a emissão do parecer de auditoria. 
4.2.1.1. As demonstrações financeiras e a operação de incorporação 62

4.2.1.2. A revisão das demonstrações financeiras 67

4.2.1.3. O parecer dos auditores independentes .71

4.2.2. A avaliação da companhia incorporada.............................................. 75

4.2.2.1. Conceitos gerais 76

4.2.2.2. Interesses tutelados e objetivo da avaliação 81

4.2.2.3. Os possíveis critérios de avaliação da companhia incorporada e a decisão acerca da sua utilização 85

4.2.2.3.1. Avaliação a valor contábil 89

4.2.2.3.2. Avaliação a valor contábil ajustado a preços de mercado.....91

4.2.2.3.3. Critérios não contábeis: (i) avaliação a valor de mercado, (ii) avaliação pelo fluxo de caixa descontado e (iii) avaliação pela comparação por múltiplos 95

4.2.2.4. Características do laudo de avaliação 101

4.2.2.5. A dupla avaliação e a relação de substituição prevista no artigo 264 da Lei das Sociedades Anônimas. 102

4.2.3. A participação dos auditores independentes nas assembleias gerais de incorporação 106

\section{DA RESPONSABILIDADE CIVIL DOS AUDITORES INDEPENDENTES NAS

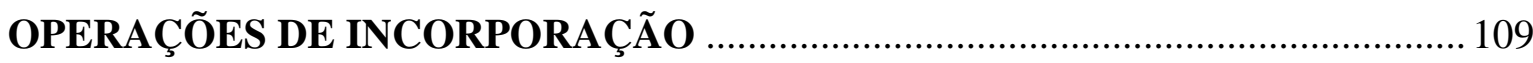

5.1. Ordens de responsabilidade civil dos auditores independentes............................. 109

5.2. Natureza da responsabilidade civil dos auditores independentes .......................... 110

5.3. Critérios e pressupostos de definição de responsabilidade 
5.3.1. Ação ou omissão dos auditores independentes ................................... 113

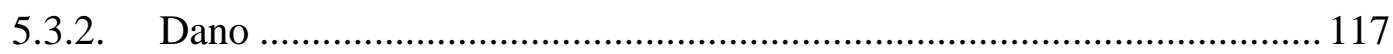

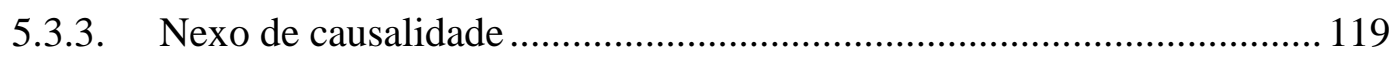

5.3.4. Responsabilidade individual e solidária ............................................. 124

5.4. Limitações à responsabilidade dos auditores independentes ................................. 125

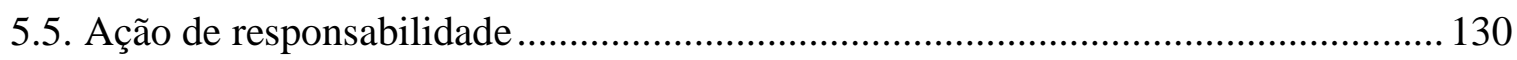

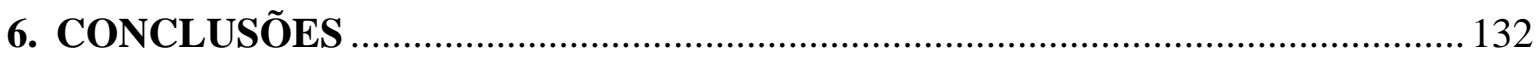

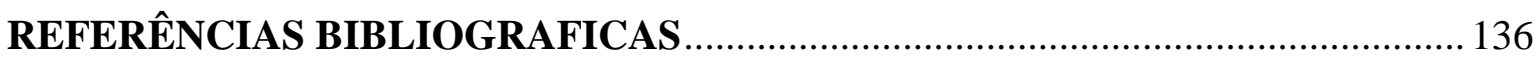




\section{INTRODUÇÃO}

A etimologia da palavra auditoria remete ao termo latim audire, que significa ouvir, sendo o auditor "aquele que ouve, ouvinte, ouvidor". No Direito Antigo, auditor era o funcionário, conhecedor das leis, responsável por informar o tribunal sobre a legalidade de certos atos ou sobre a interpretação das leis nos casos concretos ${ }^{2}$.

Conservando a conotação de especialista, ao auditor, enquanto profissional contabilista, é modernamente atribuída a função precípua de examinar e emitir parecer sobre a escrituração mercantil de uma sociedade, atestando sua exatidão dos lançamentos ou assentos constantes da escrita e a veracidade das demonstrações financeiras que lhe foram apresentadas.

Além da especialização, o que se requer dos agentes externos revisores das demonstrações financeiras é um elevado grau de confiabilidade para que a sua análise não seja influenciada por quaisquer elementos que não aqueles apresentados pelas companhias e seus órgãos quanto às atividades sociais e aos procedimentos contábeis então utilizados para refleti-las. Para tal status de confiabilidade dos auditores, dá-se o nome de independência, conceito cuja análise é essencial para o estudo de tais agentes.

A atuação dos auditores independentes, portanto, garante a fidedignidade das informações fornecidas pelas companhias e seus órgãos sociais aos mercados, exercendo essencial papel em relação à confiabilidade desses mercados, à mensuração das atividades econômicas e ao combate à assimetria de informações, sendo esta uma falha de mercado que obsta à sua eficiência ${ }^{3}$.

1 FRANÇA, Rubens Limongi. Enciclopédia Saraiva do direito, v. 9. São Paulo: Saraiva, 1978, p. 136.

2 DE PLÁCIDO E SILVA. Vocabulário jurídico. 16. ed. rev. e at. Rio de Janeiro: Forense, 1999, p. 100.

3 "O conceito de mercado eficiente, assim, está diretamente ligado à capacidade de os preços dos títulos refletirem as novas informações sobre as empresas. Quanto mais rápida for a reação da cotação dos títulos, mais eficiente, em princípio, será o mercado; o ideal é que a cotação das ações do mercado 
Tamanha importância dos serviços prestados pelos auditores independentes já justificaria a regulação pormenorizada das suas atividades. Nos dias atuais, entretanto, o grau de concentração de mercado e de especialização adquiridos pelos auditores independentes, somados à sua credibilidade pressuposta e aparência de independência, permitiu que tais profissionais desenvolvessem e prestassem uma gama maior de serviços além dos de asseguração.

Diante de tal situação, entendemos que a atividade dos auditores independentes deve ser analisada casuisticamente, de forma a identificar os potenciais riscos e responsabilidades referentes aos serviços prestados em cada hipótese específica. No presente trabalho, optou-se por proceder a tal análise em relação à atuação desses profissionais nos casos de incorporação de companhias abertas ${ }^{4}$, devido à atual importância e recorrência de tais operações e devido à relevância da atividade dos auditores para o processo de incorporação 5 .

Tais operações constituem eficiente forma de concentração societária ${ }^{6}$, que possibilitam rápida extinção de sociedades inoperantes ou com duplicidade de atividades,

secundário reflita apenas as informações disponíveis no momento". CARVALHOSA, Modesto; EIZIRIK, Nelson. A nova lei das S.A. São Paulo: Saraiva, 2002, p. 544.

4 Por questões metodológicas, decidiu-se limitar o escopo do presente trabalho ao estudo das incorporações envolvendo somente as companhias abertas, uma vez que as companhias fechadas, salvo as sociedades de grande porte, não são obrigatoriamente auditadas e não envolvem interesses dos investidores do mercado de capitais.

5 Conforme será abordado no decorrer do presente trabalho, os números contidos nas demonstrações financeiras impactam diretamente na avaliação da companhia incorporada e, por consequência, no valor do aumento do capital social da companhia incorporadora, uma vez que os diferentes critérios contábeis e econômicos de avaliação de empresas baseiam-se nas demonstrações financeiras da companhia avaliada. Dessa forma, o estudo e a regulação das atividades de revisão das demonstrações financeiras e de avaliação de empresas, realizadas pelos auditores independentes, possuem grande relevância importância no processo de incorporação, razão pela qual a Instrução CVM n $319 / 99$ dispõe, em seu artigo 12, que "as demonstrações financeiras que servirem de base para operações de incorporação, fusão e cisão envolvendo companhia aberta deverão ser auditadas por auditor independente registrado na CVM".

6 GUERREIRO, José Alexandre Tavares; TEIXEIRA, Egberto Lacerda. Das sociedades anônimas no direito brasileiro, v. 2. São Paulo: Bushatsky, 1979, p. 651. 
ganhos de sinergia por meio da concentração de esforços de administração, governança e fiscalização e a consolidação de grupos econômicos.

A opção pelo estudo da atuação dos auditores independentes na hipótese específica de uma incorporação mostrou-se mais proveitosa, uma vez que possibilitou analisar não somente a sua atividade típica de revisão de demonstrações financeiras, como também os demais serviços prestados por tais agentes, sobretudo o de avaliação de empresas e, com consequência, os problemas consequentes da concentração de tais atividades num só agente.

O presente estudo, portanto, pretende identificar os deveres e as responsabilidades dos auditores independentes nas operações de incorporação no âmbito do Direito brasileiro, não somente no que se refere ao escopo precípuo de auditoria, como também em relação aos demais serviços prestados, analisando criticamente a legalidade e as consequências da concentração de tais atividades num só agente.

Para tanto, inicialmente se discorrerá brevemente acerca da operação de incorporação, identificando as etapas em que se inserem os trabalhos dos auditores independentes. Em seguida, será analisada a atuação desses agentes em tais operações, definindo a sua relação jurídica com as companhias auditadas, o âmbito de atuação e o escopo dos seus trabalhos, os deveres gerais a estes impostos e, pormenorizadamente, os deveres específicos para cada espécie de serviço prestado.

Mais adiante, será estudado o regime de responsabilidade civil dos auditores independentes em relação à sua atuação nas operações de incorporação e, por fim, será apresentada uma conclusão sobre o presente estudo. 


\section{DAS INCORPORAÇÕES ENTRE COMPANHIAS}

\subsection{Conceito de incorporação}

As operações de incorporação possuem enorme relevância no contexto atual, servindo como eficiente ferramenta para a aquisição de participações societárias, bem como para reorganizações societárias de consolidação de grupos econômicos.

No século XIX, entretanto, entendia-se que a operação de incorporação, ao contrário da fusão, poderia ser entendida como a mera compra e venda ou cessão da indústria, do fundo ou do negócio de uma sociedade a outra, e não se verificava qualquer especificidade além de uma operação que condensava um aumento do capital social do incorporador e um meio rápido e econômico de liquidação da sociedade incorporada ${ }^{7,8}$.

Diante de tal situação, não obstante em tal período pudessem ser apurados raros indícios de uma tendência à utilização do instituto, como no estatuto social da Companhia Mogiana de Estradas de Ferro, que previu em seu artigo 46 um quórum qualificado para a aprovação de sua incorporação em outra sociedade, tanto a Lei 556, de 25 de junho de 1850 (o Código Comercial), como o Decreto 434, de 4 de julho de 1891, não previam quaisquer regras a respeito da operação de incorporação 9 .

7 A respeito, cf. CARVALHO DE MENDONÇA, José Xavier. Tratado de direito comercial brasileiro, v. 4. 4. ed. Rio de Janeiro/São Paulo: Freitas Bastos, 1946, p. 197-198.

8 Ressalte-se, entretanto, que, conquanto essa não seja a definição precisa de incorporação nos dias atuais, a melhor doutrina reconhece que essa espécie de operação apresenta proximidade com a operação de aumento de capital com subscrição em bens, sendo a semelhança entre tais operações de fundamental importância para determinadas proposições e, sobretudo, para a distinção com o instituto da fusão. Conforme COMPARATO "enquanto a fusão configura procedimento societário análogo ao de fundação de uma sociedade, a incorporação se aproxima de um aumento de capital por subscrição em bens" COMPARATO, Fabio Konder. Novos ensaios e pareceres de direito empresarial. Rio de Janeiro: Forense, 1981, p. 206.

9 CARVALHO DE MENDONÇA, José Xavier. Tratado, op. cit., v. 4, p. 197-198. 
No direito continental europeu, o primeiro ordenamento jurídico a tratar da incorporação (como uma espécie do gênero fusão) foi o Código de Comércio Italiano de 1883, em seus artigos 193 a 196. Na Alemanha a primeira lei a disciplinar a incorporação foi a Aktiengesetz de 1937, enquanto na Espanha o diploma pioneiro foi a Lei das Sociedades Anônimas de $1951^{10}$.

Já o legislador brasileiro de 1940 mostrou-se atento à importância crescente do instituto e à necessidade de garantir que tais operações fossem procedidas de forma a atender aos interesses da sociedade, dos sócios minoritários e dos credores. Dessa forma, o Decreto-Lei 2.627/40, em seu artigo 152, previu um tratamento específico às incorporações ${ }^{11}$, o que seria o início de uma regulação sobre a matéria.

A Lei 6.404/76, por sua vez, previu um tratamento mais específico ao tema das incorporações, com garantias e procedimentos que tutelam os direitos dos sócios e dos credores e os interesses da companhia. Em seu artigo 227, definiu a incorporação como uma operação em que uma ou mais sociedades são absorvidas por outra, que as sucede em

10 Embora os textos legais anteriores de ambos os países, porém, já previam uma regulação ínfima dentro de artigos que tratavam de matérias diversas. A respeito, cf. GARRIGUES, Joaquin; URÍA, Rodrigo. Comentarios a la ley de sociedades anónimas, t. 1. Madrid: Instituto de Estudios Politicos, 1952, p. 595 596.

11 "Art. 152. A incorporação é a operação pela qual uma ou mais sociedades são absorvidas por outra, que lhes sucede em todos os direitos e obrigações.

$\S 1^{\circ}$ A sociedade anônima incorporadora deverá, em assembléia geral, na forma desta lei, aprovar as bases da operação e o projeto de reforma dos estatutos. As sociedades que houverem de ser absorvidas tomarão conhecimento desses atos e, si os aprovarem, autorizarão os administradores a praticar os atos necessários à incorporação, inclusive a subscrição em bens pelo valor que se verificar entre o ativo e o passivo.

$\S 2^{\circ}$ A assembléia geral da sociedade anônima incorporadora nomeará os peritos para a avaliação do patrimônio líquido das sociedades que tenham de ser incorporadas, e, aprovado o láudo da avaliação, promoverão os diretores daquela sociedade o arquivamento e a publicação dos respectivos atos.

$\S 3^{\circ}$ Os sócios ou acionistas das sociedades incorporadas, aprovado o láudo da avaliação pela assembléia geral da sociedade anônima, incorporadora, deverão reunir-se e declarar extintas as sociedades incorporadas, arquivando-se e publicando-se em seguida os respectivos atos, juntamente com os referidos no parágrafo anterior." 
todos os direitos e obrigações ${ }^{12}$. Como consequência, há a extinção da pessoa jurídica da sociedade incorporada, e a emissão de ações da companhia incorporadora para subscrição pelos antigos acionistas da sociedade incorporada ${ }^{13}$.

Nesse sentido, afirmam GUERREIRO e TEIXEIRA que

a incorporação implica a transferência do patrimônio líquido da sociedade incorporada para a sociedade incorporadora, à semelhança do que ocorre com a versão de bens para a constituição de nova companhia, ou seja, mediante a subscrição de capital da incorporadora, efetuada pelos acionistas da incorporada. ${ }^{14}$

Portanto, infere-se que as incorporações possuem como características: (i) ser um processo eminentemente societário, ou seja, efetivado sempre entre duas ou mais sociedades (art. 227); (ii) a absorção de sociedade ou sociedades, por outra sociedade (art. 227); (iii) a transmissão global do patrimônio - todos os direitos e obrigações - e a sucessão universal, "opus legis"; (iv) a participação dos acionistas ou sócios das incorporadas diretamente na sociedade incorporadora; e (v) a extinção das sociedades incorporadas e a permanência da incorporadora ${ }^{15}$.

12 No mesmo sentido, cf. também (i) FERRI, Giuseppe. Le società. Torino: Torinese, 1971, p. 695; (ii) RIPERT, Georges. Traité élémentaire de droit commercial. Paris: LGDJ, 1974, p. 911; e (iii) CLARK, Robert Charles. Corporate law. Boston: Aspen, 1986, p. 417.

13 No Direito Comunitário Europeu, previsão similar é verificada no artigo 19 da Diretiva 2011/35/EU, de 5 de abril de 2011, segundo o qual "A fusão produz ipso iure e simultaneamente os seguintes efeitos: a) A transmissão universal do conjunto do património activo e passivo da sociedade incorporada para a sociedade incorporante, tanto no que a estas respeita como relativamente a terceiros; $b$ ) Os accionistas da sociedade incorporada tornam-se accionistas da sociedade incorporante; c) A sociedade incorporada extingue-se".

14 GUERREIRO, José Alexandre Tavares; TEIXEIRA, Egberto Lacerda. Das sociedades, op. cit., v. 2, p. 665 .

15 BULGARELLI, Waldirio. Fusões, incorporações e cisões de sociedades. 2. ed. São Paulo: Atlas, 1996, p. 213. 
Ressalte-se, afinal, que no Direito brasileiro a incorporação é conceituada como um gênero próprio, diverso da fusão ${ }^{16}$, aproximando-se de uma operação de aumento de capital mediante subscrição de bens ${ }^{17}$. Já no direito comparado, nota-se que a maioria dos ordenamentos jurídicos conceituam a incorporação como uma espécie do gênero fusão, conforme observa-se no art. $23^{18}$ da Ley 3/2009 da Espanha, no art. $2501^{19}$ Codice Civile da Itália, no art. L236-1 $1^{20}$ do Code du Commerce da França e no art. $97^{21}$ do Código das Sociedades Comerciais de Portugal.

\subsection{Fases e procedimentos}

Quanto aos procedimentos, entende-se que as operações de incorporação são divididas em três fases ${ }^{22,23,24}$ sucessivas, quais sejam, (i) a negociação das condições da

16 Conforme o artigo 228 da Lei das Sociedades Anônimas, "A fusão é a operação pela qual se unem duas ou mais sociedades para formar sociedade nova, que lhes sucederá em todos os direitos e obrigações".

17 COMPARATO, Fabio Konder. Novos ensaios e pareceres de direito empresarial. Rio de Janeiro: Forense, 1981, p. 207.

18 "Artículo 23. Clases de fusión.

1. La fusión en una nueva sociedad implicará la extinción de cada una de las sociedades que se fusionan y la transmisión en bloque de los respectivos patrimonios sociales a la nueva entidad, que adquirirá por sucesión universal los derechos y obligaciones de aquéllas.

2. Si la fusión hubiese de resultar de la absorción de una o más sociedades por otra ya existente, ésta adquirirá por sucesión universal los patrimonios de las sociedades absorbidas, que se extinguirán, aumentando, en su caso, el capital social de la sociedad absorbente en la cuantía que proceda."

19 "Art. 2501. Forme di fusione. La fusione di più società (att. 211) può eseguirsi mediante la costituzione di una società nuova, o mediante l'incorporazione in una società di una o più altre."

20 "Une ou plusieurs sociétés peuvent, par voie de fusion, transmettre leur patrimoine à une société existante ou à une nouvelle société qu'elles constituent."

21 "A fusão pode realizar-se:

a) Mediante a transferência global do património de uma ou mais sociedades para outra e a atribuição aos sócios daquelas de partes, acções ou quotas desta;

b) Mediante a constituição de uma nova sociedade, para a qual se transferem globalmente os patrimónios das sociedades fundidas, sendo aos sócios destas atribuídas partes, acções ou quotas da nova sociedade."

22 Cf. (i) LAMY FILHO, Alfredo; PEDREIRA, José Luiz Bulhões. Direito das companhias, v. 1. Rio de Janeiro: Forense, 2009, p. 1146-1147; e (ii) BULGARELLI, Waldirio. Fusões, op. cit., p. 119-120. 
operação, (ii) a aprovação dos órgãos sociais das companhias envolvidas, e (iii) os registros e demais atos a serem praticados para a sua execução.

$\mathrm{Na}$ primeira fase, portanto, os administradores ${ }^{25} \mathrm{e} / \mathrm{ou}$ acionistas de ambas as companhias envolvidas deverão discutir as peculiaridades do negócio jurídico e negociar os termos e as condições da operação de incorporação, elaborando, como consequência, um instrumento de protocolo e um instrumento de justificação da operação ${ }^{26}$.

De acordo com o artigo 224 da Lei das Sociedades Anônimas, o instrumento de protocolo de incorporação deve conter (i) o número, a espécie e a classe das ações que serão atribuídas em substituição dos direitos de sócios que se extinguirão e os critérios utilizados para determinar as relações de substituição; (ii) os critérios de avaliação do patrimônio líquido, a data a que será referida a avaliação, e o tratamento das variações

23 A mesma divisão existe também no direito italiano, conforme GALGANO e GENCHINI: "Il procedimento di fusione si attua, secondo le norme emanate in attuazione della direttiva comunitaria in materia, attraverso una triplice fase: la prima fase ha per protagonisti gli amministratori delle società che partecipano alla fusione, i quali debbono un progetto di fusione [...]. La seconda fase ha per protagoniste le assemblee delle società partecipanti alla fusione [...]. La terza fase ha di nuovo per protagonisti gli amministratori delle società partecipanti alla fusione, che questa volta operano conjiuntamente: da essi viene redatto l'atto di fusione, per il quale è richiesta la forma dell atto publico, oltre che l'inscrizione nel registro delle imprese." GALGANO, Francesco. GENCHINI, Riccardo. Il nuovo diritto societario, t. 1. Padova: CEDAM, 2006, p. 1004-1005.

24 EIZIRIK considera haver quatro fases, pois, de acordo com a classificação do autor, entre a fase de aprovação do protocolo e da justificação da operação pelas assembléias gerais e a fase em que se procedem aos registros e demais atos complementares, há uma fase de efetiva implementação da operação, "mediante aumento do capital social da sociedade incorporadora, integralizando o patrimônio da incorporada, e entrega das ações da incorporadora aos acionistas da incorporada, em substituição aos títulos que antes dela detinham". EIZIRIK, Nelson. A lei das S/A comentada, v. 3. São Paulo: Quartier Latin, 2011, p. 247.

25 Infere-se, pois, que a negociação dos termos e condições do processo de incorporação, quando não procedida pelos próprios acionistas, caberá especificamente aos diretores, devendo tais termos e condições ser referendados pelo conselho de administração e aprovados pela assembleia geral de ambas as sociedades envolvidas. Tal interpretação fundamenta-se no parágrafo primeiro do artigo 138 da Lei das Sociedades Anônimas, segundo o qual "o conselho de administração é órgão de deliberação colegiada, sendo a representação da companhia privativa dos diretores". A respeito, cf. (i) BORBA, José Edwaldo Tavares. Direito societário. Rio de Janeiro: Freitas Bastos, 1995, p. 335; e (ii) EIZIRIK, Nelson. Temas de direito societário. Rio de Janeiro: Renovar, 2005, p. 58 e (iii) LUCENA, José Waldecy. Das sociedades anônimas - comentários à lei (arts. 121 a 188), v. 2. Rio de Janeiro: Renovar, 2009, p. 281282.

$26 \mathrm{Ou}$, simplesmente, um único instrumento de protocolo e justificação, conforme a prática empresarial mais comum. 
patrimoniais posteriores; (iii) a solução a ser adotada quanto às ações ou quotas do capital de uma das sociedades possuídas por outra; (iv) o valor do capital das sociedades a serem criadas ou do aumento ou redução do capital das sociedades que forem parte na operação; (v) o projeto ou projetos de estatuto, ou de alterações estatutárias, que deverão ser aprovados para efetivar a operação; e (vi) todas as demais condições a que estiver sujeita a operação.

Já o instrumento de justificação, prevê o artigo 225 da Lei das Sociedades Anônimas, deverá mencionar, com relação à incorporação, (i) os motivos ou fins da operação, e o interesse da companhia na sua realização, (ii) as ações que os acionistas preferenciais receberão e as razões para a modificação dos seus direitos, se previstas, (iii) a composição, após a operação, segundo espécies e classes de ações, do capital das companhias que deverão emitir ações em substituição às que se deverão extinguir, e (iv) o valor de reembolso das ações a que terão direito os acionistas dissidentes.

Historicamente, o revogado Decreto-Lei 2.627/40 foi o primeiro diploma legal brasileiro a prever similar exigência de prestação de informações relevantes relativas à incorporação, ao dispor, em seu artigo $152, \S 1^{\circ}$ que

a sociedade anônima incorporadora deverá, em assembléia geral, na forma desta lei, aprovar as bases da operação e o projeto de reforma dos estatutos. As sociedades que houverem de ser absorvidas tomarão conhecimento desses atos e, si os aprovarem, autorizarão os administradores a praticar os atos necessários à incorporação, inclusive a subscrição em bens pelo valor que se verificar entre o ativo e o passivo. (grifo nosso)

A análise do revogado dispositivo, entretanto, revelava a expressão "bases da operação" como um tanto imprecisa, o que implicava, durante o regime anterior, menor segurança no recebimento de informações suficientes para a compreensão da incorporação e para a deliberação sobre ela e possibilitava abusos e descuidos por parte dos controladores, administradores e avaliadores nas operações de incorporação.

Diante de tal quadro, a atual Lei das Sociedades Anônimas, ao prever o dever de elaboração dos instrumentos de protocolo e justificação nos atuais termos, acertou ao assegurar aos acionistas "o conhecimento de todas as condições da operação, das 
repercussões que terá sobre os seus direitos, e do valor de reembolso que lhes caberá, caso prefiram usar do direito de retirada"27. Trata-se, pois, de moderna imposição, semelhante ao que se verifica no direito comparado ${ }^{28}$.

Na segunda fase, de formação do negócio jurídico, as partes envolvidas deverão submeter à deliberação de seus órgãos sociais a operação de incorporação e os seus termos e condições, decidindo, portanto, sobre os instrumentos de protocolo e justificação. Nesse ponto, cabem importantes comentários acerca das deliberações sociais de ambas as sociedades envolvidas na operação de incorporação.

Em relação à sociedade incorporadora, deverão os seus sócios, por meio de uma primeira assembleia geral extraordinária, analisar a justificação apresentada pela administração e aprovar os termos e as condições pactuados e consubstanciados no instrumento de protocolo, autorizando (i) o aumento do capital a ser subscrito e realizado pela incorporadora mediante versão do seu patrimônio líquido, e (ii) a nomeação dos peritos que o avaliarão ${ }^{29}$.

27 Conforme Exposição de Motivos n 196, de 24 de junho de 1976, do Ministério da Fazenda.

28 A respeito, cf. (i) "progetto di fusione" previsto no artigo 2501 do Codice Civile italiano; (ii) "proyecto de fusión" previsto nos arts. 30 a 35 da Ley 3/2009 da Espanha; (iii) "projecto de fusão" previsto no artigo 98 do Codigo das Sociedades Comerciais de Portugal; (iv) "projet de fusion" previsto no artigo L236-6 do Code du Commerce da França. A respeito, cf. ainda o artigo $5^{\circ}$ da Diretiva 2011/35/EU, de 5 de abril de 2011, segundo o qual os órgãos da administração ou de direção das sociedades participantes da incorporação deverão elaborar um projeto de fusão, o qual conterá, pelo menos, “a) $O$ tipo, a denominação e a sede social das sociedades participantes na fusão; b) A relação de troca das acções e, se for caso disso, a quantia em dinheiro atribuída aos accionistas; c) As modalidades de entrega das acções da sociedade incorporante; d) A data a partir da qual essas acções conferem o direito aos dividendos, bem como qualquer especialidade relativa a esse direito; e) A data a partir da qual as operações das sociedades incorporadas serão consideradas, do ponto de vista contabilístico, efectuadas por conta da sociedade incorporante; f) Os direitos assegurados pela sociedade incorporante aos accionistas que gozem de direitos especiais e aos portadores de títulos diferentes das acções, ou as medidas propostas relativamente a eles; g) Todas as vantagens especiais atribuídas aos peritos referidos no n. o 1 do artigo 10. o e aos membros dos órgãos de administração, de direcção, de vigilância ou de fiscalização das sociedades participantes na fusão".

29 Parágrafo $1^{\circ}$ do artigo 227 da Lei das Sociedades Anônimas. 
O aumento de capital aprovado na primeira assembleia geral da sociedade incorporadora, contudo, não poderá ser efetivado sem que seja concluída a operação de incorporação, razão pela qual tal aprovação não será eficaz até o momento da conclusão de uma segunda assembleia geral, que ocorrerá, portanto, com vistas (i) à aprovação do laudo de avaliação elaborado pelos peritos ou pela empresa especializada, e (ii) à ratificação da aprovação para o aumento do capital social da sociedade incorporadora mediante a conferência do patrimônio líquido da incorporada ao seu próprio capital social.

Todavia, ressalte-se que, por questões de economia procedimental, na prática empresarial usualmente se realiza uma só assembleia geral da sociedade incorporadora, em que se aprova o instrumento de protocolo e justificação, a nomeação dos peritos, o laudo de avaliação $^{30}$ e o aumento de capital mediante a versão do patrimônio líquido da incorporada ao capital social da incorporadora. Tal prática não constitui violação dos preceitos legais, é aceita pela doutrina pátria ${ }^{31}$, e está em consonância com o que se espera dos modernos procedimentos de incorporação, tendo em vista que "o que se reclama é que seja ágil e flexível, sem formalidades excessivas e muitas vezes custosas, que poderão, como é evidente, impedir a sua utilização na prática"32.

Do ponto de vista societário, portanto, procedendo a sociedade incorporadora a uma ou duas assembleias gerais com o fim de realizar a incorporação, a condição necessária para a concretização da incorporação é a aprovação de todas as deliberações essenciais previstas em lei, quais sejam, (i) a aprovação do instrumento de protocolo e justificação,

30 No caso de nomeação dos peritos e aprovação do laudo de avaliação numa só assembleia geral, como não haveria tempo hábil para elaboração dos laudos de avaliação, pode-se entender que o papel da assembleia geral na prática subverte-se no de ratificar a contratação dos peritos já anteriormente contratados, e em seguida aprovar o laudo de avaliação por estes preparado.

31 A respeito, cf. (i) LAMY FILHO, Alfredo; PEDREIRA, José Luiz Bulhões. A Lei das S.A.: (pressupostos, elaboração, aplicação). 3. ed. Rio de Janeiro: Renovar, 1997, p. 588 e ss., e Direito, op. cit., v. 2, p. 1.800; e (ii) CARVALHOSA, Modesto. Comentários à Lei das Sociedades Anônimas, v. 4, t. 1, p. 266.

32 BULGARELLI, Waldirio. Fusões, op. cit., p. 207. Ressalva o autor tal assertiva, contudo, afirmando que "essa flexibilidade não deve ser de molde a permitir que tanto os acionistas minoritários como os credores possam ser prejudicados". BULGARELLI, Waldirio. Fusões, incorporações e cisões de sociedades. 2. ed. São Paulo: Atlas, 1996, p. 207. 
(ii) a nomeação dos peritos avaliadores, (iii) a aprovação do aumento do capital social como consequência da operação (e/ou a sua ratificação), bem como (iv) a aprovação do laudo de avaliação elaborado pelos peritos avaliadores.

Não obstante, a competência da assembleia geral extraordinária da sociedade incorporadora limita-se à aprovação da avaliação da sociedade incorporada e da consequente relação de troca proposta sobre as ações das sociedades envolvidas, não sendo tal assembleia, pois, competente para deliberar sobre a reavaliação da sociedade incorporada (ou a alteração do respectivo laudo de avaliação), ou mesmo a alteração de quaisquer das condições propostas pela administração quanto à operação de incorporação $^{33}$. Tampouco poderiam os acionistas dissidentes da sociedade incorporadora propor a anulação da assembleia geral extraordinária que aprovou a incorporação pela mera discordância com quaisquer dos termos propostos, inclusive os critérios de avaliação utilizados, pois tal discordância seria uma ofensa ao princípio majoritário que guia a atual lei do anonimato ${ }^{34}$.

Por estes e outros motivos, conforme será abordado ao longo do presente trabalho, a atuação dos auditores independentes, como prestadores de serviços de asseguração e/ou de avaliação, será essencial para o deslinde da operação de incorporação, e, sobretudo, para que ela ocorra de forma satisfatória aos interesses da companhia e dos seus acionistas.

Ademais, em vista da proximidade do instituto da incorporação com a operação de aumento de capital mediante subscrição de bens no direito brasileiro, a aplicação do parágrafo $1^{\circ}$ do artigo $8^{\circ}$ da Lei das Sociedades Anônimas às operações de incorporação implica, nessa segunda fase do processo de incorporação, implica a obrigatoriedade do

33 A respeito, cf. (i) CARVALHO DE MENDONÇA, José Xavier. Tratado, op. cit., v. 3, p. 358-359; e (ii) CARVAlHOSA, Modesto. Comentários, op. cit., v. 1. São Paulo: Saraiva, 2003, p. 121.

34 Obviamente, excepciona-se tal impossibilidade de pleitear a anulação assemblear se verificada a ocorrência de quaisquer hipóteses de causa de nulidade de assembleia geral. A respeito, cf. (i) ASCARELLI, Tullio. Problemas das sociedades anônimas e direito comparado. 2. ed. São Paulo: Saraiva, 1969, p. 372 e ss.; e (ii) Invalidade de deliberações conexas de companhia. FRANÇA, Erasmo Valladão Azevedo e Novaes. Revista de Direito Mercantil Industrial, Econômico e Financeiro, ano XLVI, n. 145, p. 255-269. São Paulo: Malheiros, jan./mar. 2007. 
comparecimento à assembleia geral da companhia incorporadora dos peritos ou dos representantes da empresa especializada responsável pela avaliação, que poderá ser uma empresa de auditoria independente, para prestarem esclarecimentos e informações necessários.

No que compete às deliberações sociais da sociedade incorporada, note-se que a Lei das Sociedades Anônimas não previu qualquer aprovação específica acerca da operação de incorporação. Às incorporações, novamente, aplica-se o artigo $8^{\circ}$ da Lei das Sociedades por Ações, do qual destacamos os parágrafos $2^{\circ}$ e $3^{\circ}$, os quais são claros ao dispor que a assembleia geral da companhia recebedora da contribuição de capital deverá aprovar a avaliação dos bens a serem conferidos, cabendo ao acionista subscritor tão somente a $\underline{\text { aceitação ou não da avaliação aprovada }}{ }^{35,36}$.

Tal assertiva baseia-se, sobretudo, nas restrições aplicáveis à hipótese de conflito de interesses dos acionistas ${ }^{37}$, tanto o é que o próprio parágrafo $5^{\circ}$ do artigo $8^{\circ}$ da Lei das Sociedades Anônimas prevê a aplicação do disposto nos parágrafos $1^{\circ}$ e $2^{\circ}$ do artigo 115 da mesma lei; entre tais restrições, encontra-se a vedação aos acionistas de votarem nas assembleias gerais relativas ao laudo de avaliação dos bens com que concorrerem para a formação do capital social, hipótese denominada pela doutrina como conflito formal de interesses, ou proibição de voto ${ }^{38}$.

35 Conforme COMPARATO, "na incorporação comum, sendo o procedimento assimilável ao de aumento de capital de uma companhia mediante subscrição em bens, a avaliação do patrimônio líquido da sociedade incorporada é decidida e aprovada pela incorporadora. Aos sócios ou acionistas da incorporada, enquanto subscritores, compete apenas aceitar ou não aceitar essa avaliação, mas nunca aprová-la; porque, obviamente, o subscritor não pode aprovar o laudo de avaliação dos bens com que concorre para a formação do capital subscrito" (grifo nosso). COMPARATO, Fabio Konder. Novos ensaios e pareceres de direito empresarial. Rio de Janeiro: Forense, 1981, p. 207.

36 Já a Diretiva 2011/35/EU, de 5 de abril de 2011, talvez por considerar a incorporação como uma espécie do gênero fusão, conforme título do seu Capítulo III, prevê expressamente em seu artigo $7^{\circ}$ a efetiva aprovação da operação, pelo menos, pela assembleia geral de cada uma das sociedades participantes.

37 COMPARATO, Fabio Konder. Novos ensaios, op. cit., p. 207.

38 A respeito, cf. FRANÇA, Erasmo Valladão Azevedo e Novaes. Conflito de interesses nas assembleias de S.A. São Paulo: Malheiros, 1993, p. 87. 
CARVALHOSA ${ }^{39}$ parece concordar com a aplicação do artigo $8^{\circ}$ da Lei das Sociedades Anônimas e com a consequente ideia de mútua manifestação de vontade de ambas as partes para a operação de incorporação. Entretanto, o fato de tal analogia implicar a manifestação de vontade de ambas as sociedades, incorporadora e incorporada, parece ter levado tal autor a confundir a aprovação requerida de uma com a aceitação da outra, distinção fundamental para a definição das competências para a anulação da assembleia, como bem observou COMPARATO ${ }^{40}$.

Obviamente, assim como na sociedade incorporadora, a assembleia geral extraordinária da sociedade incorporada não possui competência para a alteração do laudo de avaliação ou de quaisquer das condições propostas relativas à incorporação, mas tão somente para aceitá-los ou não, hipótese em que a operação restará prejudicada ${ }^{41}$. Ademais, os acionistas da sociedade incorporada são partes ilegítimas para pleitear a anulação ou a declaração de nulidade (i) tanto da assembleia geral da sociedade incorporadora, pois tal aprovação não deve tutelar os interesses dos acionistas de outra companhia, quanto (ii) da própria assembleia geral da sociedade incorporada, uma vez que tal possibilidade constituiria uma vedação ao princípio majoritário, e, no caso da anulação por discordância com os critérios de avaliação, não cabe aos acionistas da sociedade incorporada aprovar a avaliação do seu próprio patrimônio líquido utilizado para a conferência de capital ${ }^{42}$.

Ainda, como regra geral nas incorporações, não se deve proceder a uma avaliação da sociedade incorporadora ${ }^{43,44}$, mesmo que com o fim de fixação do cálculo da relação de

39 CARVAlhOSA, Modesto. CARVAlhOSA, Modesto. Comentários, op. cit., v. 4, t. 1, p. 280.

40 COMPARATO, Fabio Konder. Novos ensaios, op. cit., p. 208.

41 CARVAlhOSA, Modesto. Comentários, op. cit., v. 4, t. 1, p. 280.

42 COMPARATO, Fabio Konder. Novos ensaios, op. cit., p. 204-214.

43 GUERREIRO, José Alexandre Tavares; TEIXEIRA, Egberto Lacerda. Das sociedades, op. cit., v. 2, p. 667.

44 Bem como, por consequência, não deve haver uma aprovação de tal avaliação pela assembleia geral extraordinária da sociedade incorporadora. 
troca das ações da sociedade incorporada, detida pelos seus sócios, com as novas ações da sociedade incorporadora a serem por estes subscritas. Tal previsão se deve ao fato de, conforme disposto anteriormente, no Direito Brasileiro, a incorporação possuir o status de uma estruturação societária completamente diversa da fusão, sendo esta comparável a uma fundação de uma sociedade, e aquela comparável a um aumento de capital por subscrição de bens ${ }^{45}$.

Ademais, é também nessa segunda fase do processo de incorporação que será garantido aos acionistas minoritários dissidentes da sociedade incorporada o direito de recesso $^{46}$, a ser exercido em trinta dias contados da publicação da ata que aprovar o protocolo ou a justificação; o pagamento do valor de reembolso, entretanto, é devido somente se a operação vier a efetivar-se. Tal direito não será garantido quando o acionista dissidente possuir ações com liquidez e dispersão ${ }^{47}$ no mercado ${ }^{48}$ e, exceção feita às incorporações envolvendo companhias controladas ou sob controle comum, como será abordado a seguir, o valor de reembolso seguirá a regra do artigo 45 da Lei das Sociedades Anônimas.

"Não faz sentido impor-se, na incorporação, a estimação do valor patrimonial da incorporadora, isto é, da sociedade receptora do patrimônio da incorporada”. COMPARATO, Fabio Konder. Novos ensaios e pareceres de direito empresarial. Rio de Janeiro: Forense, 1981, p. 206.

46 Conforme o caput do artigo 137 combinado com o inciso IV do artigo 136 da Lei das Sociedades Anônimas.

47 De acordo com o artigo 137, II da Lei das Sociedades Anônimas, o conceito de liquidez refere-se à espécie ou classe de ação, ou certificado que a represente, integre índice geral representativo de carteira de valores mobiliários admitido à negociação no mercado de valores mobiliários, no Brasil ou no exterior, definido pela Comissão de Valores Mobiliários, e o conceito de dispersão refere-se à situação em que o acionista controlador, a sociedade controladora ou outras sociedades sob seu controle detiverem menos da metade da espécie ou classe de ação.

48 Nos Estados Unidos, conforme EASTERBROOK e FISCHEL, as legislações societárias de vinte e três estados preveem restrição similar ao direito de recesso (appraisal rights) em relação às companhias de capital aberto e outras cujas ações possuam suficiente liquidez e dispersão. EASTERBROOK, Frank; FISCHEL, Daniel. The economic structure of corporate law: trading on inside information. Cambridge: Harvard University Press, 1996, p. 149. A respeito, cf. também KLEIN, William A.; COFFEE JR., John C.; PARTNOY, Frank. Business organization and finance - legal and economic principles. New York: Foundation Press, 2010, p. 215-219. 
Finalmente, na terceira fase da operação de incorporação deverão ocorrer os atos relativos aos registros e outros a serem praticados para a sua execução. Em seu artigo 227, $\S 3^{\circ}$, a Lei das Sociedades Anônimas prevê a responsabilidade da sociedade incorporadora no arquivamento dos atos societários de incorporação perante a junta comercial e outros órgãos competentes, bem como a publicação de seus atos societários no diário oficial e em jornais de grande circulação.

Sobre o processo de registro, é importante ressaltar, em primeiro lugar, que o artigo 36 da Lei 8.934/94 estabelece a retroatividade do arquivamento dos atos societários registrados dentro de trinta dias da data da sua lavratura, e que a Lei das Sociedades Anônimas em seu artigo 134, prevê que a certidão, passada pelo registro do comércio, da incorporação, da fusão ou da cisão, é documento hábil para a averbação, nos registros públicos competentes, da sucessão, decorrente da operação, em bens, direitos e obrigações.

Especificamente quanto às incorporações envolvendo companhias abertas, a lei dispõe que a sociedade incorporadora deverá obter o registro de companhia aberta perante a Comissão de Valores Mobiliários (CVM) em 120 dias contados da data da assembleia geral que aprovou a operação. Sobre tal espécie de incorporação, aliás, a CVM editou, em 3 de dezembro de 1999, a Instrução Normativa no 319, com que, conforme será abordado com mais detalhes ao longo do presente trabalho, impôs diversos deveres aos acionistas e administradores, relativos (i) à divulgação de informações, (ii) ao aproveitamento econômico e tratamento do ágio, (iii) à relação de substituição das ações dos acionistas, (iv) à obrigatoriedade de auditoria independente das demonstrações financeiras, (v) ao conteúdo do relatório da administração, (vi) às hipóteses de exercício abusivo do poder de controle, e (vii) ao fluxo de dividendos dos acionistas não-controladores.

\subsection{Das incorporações envolvendo companhias controladas ou sob controle comum}

\subsection{1. $\quad$ Especificidades jurídicas e contábeis}


No item anterior abordamos o regramento geral imposto pelo ordenamento jurídico brasileiro às incorporações entre companhias, que prevê condições suficientes para garantir que as operações sejam transparentes e equitativas em hipóteses ordinárias. Entretanto, parece claro que as regras gerais sobre incorporação previstas na Seção II do Capítulo XVIII da Lei das Sociedades por Ações não regulam completamente determinadas hipóteses peculiares de incorporação.

Exemplo de tal insuficiência é o caso da incorporação de sociedade com patrimônio líquido negativo, hipótese comum em reestruturações de grupos societários, e que parece ter fugido do escopo da lei. Sobre essa hipótese, embora se verifiquem esforços da doutrina $^{49}$ e da jurisprudência ${ }^{50}$, com importantes conclusões sobre a consequências em relação ao patrimônio líquido final da sociedade incorporadora ${ }^{51}$, restam ainda pendentes conclusões acerca da potencial exclusão dos sócios da sociedade incorporada em face da impossibilidade de aumento do capital social, entre outros pontos.

49 Como referência, cf. (i) LAMY FILHO, Alfredo; PEDREIRA, José Luiz Bulhões. Direito, op. cit., v. 2 , p.1785; e (ii) NEVES, Maria Cecília de Castro. Incorporação de sociedade com patrimônio líquido negativo. Revista Forense, v. CCCXLV, p.103, São Paulo, jan/mar. 1999.

50 Cf. (i) Parecer Conjur 129/96; e (ii) Parecer Jucesp nº 201/89.

51 Nesses casos, entende-se que, em regra, a incorporação de sociedade com patrimônio líquido negativo deve implicar redução do capital social da sociedade incorporadora, uma vez que esta deve absorver os prejuízos da sociedade incorporada. Entretanto, admite-se a possibilidade de compensação, no momento da incorporação, do patrimônio líquido negativo da sociedade incorporada com eventual lucro da sociedade controladora ou outras reservas contidas em seu patrimônio líquido, de forma a não haver a redução do seu capital social como consequência da operação. Em raciocínio análogo, ainda, caso não haja lucros ou reservas a serem compensados com o patrimônio líquido negativo incorporado, é possível à sociedade incorporadora provisionar uma conta em seu passivo para compensar o patrimônio líquido negativo da sociedade controlada no momento da incorporação, de forma a não haver uma redução do capital social da sociedade incorporadora como consequência da operação. Entendemos tal possibilidade, entretanto, aceitável somente no caso de incorporação de uma sociedade controlada ou de uma subsidiária integral, pois, como a sócia controladora não responde diretamente pelas dívidas da sociedade controlada (exceto em hipóteses específicas como na desconsideração da personalidade jurídica, em assunção de dívidas solidárias, em prestação de garantias à sociedade controlada, dentre outras), a provisão de uma conta em seu passivo circulante somente seria justificável como forma de garantir a saúde financeira do seu grupo econômico como um todo. Outra limitação a tal hipótese é também a obrigatoriedade de que tal provisão no passivo da sociedade incorporadora seja limitada ao valor da sua participação na sociedade controlada (incorporada), uma vez que uma provisão maior seria equivalente à assunção da parcela dos demais sócios sobre o patrimônio líquido negativo da sociedade incorporada, i.e., equivaleria à assunção de uma dívida que não existe, a um montante não devido. 
Outra hipótese excepcional é exatamente o caso das incorporações envolvendo companhias controladas. Trata-se de hipótese absolutamente especial do ponto de vista societário e contábil, que

requer normas especiais para a proteção de acionistas minoritários, por isso que não existem, na hipótese, duas maiorias acionárias distintas, que deliberem separadamente sobre a operação, defendendo os interesses de cada companhia. ${ }^{52}$

Do ponto de vista contábil, tal hipótese diferencia-se das incorporações em que não há participação societária entre as sociedades envolvidas, pois a parcela do patrimônio da sociedade controlada correspondente às ações da controladora irá exatamente substituir essas ações no patrimônio da controladora ${ }^{53}$. Em outras palavras,

são vertidos todos os ativos e passivos da controlada para a controladora, [...] mas haverá aumento de capital em A (incorporadora) para os acionistas não controladores de B (incorporada) que agora se tornarão acionistas de A. ${ }^{54}$

No limite, analisando uma hipótese de incorporação de um tipo específico de sociedade controlada, que é a subsidiária integral, verifica-se que tal incorporação implicará a extinção da sociedade incorporada com a versão dos seus ativos e passivos pela sociedade incorporadora, porém sem ocorrer qualquer aumento do capital social da sociedade incorporadora, havendo tão somente "uma modificação dos seus registros ativos" ${ }^{, 55}$.

52 Conforme Exposição de Motivos no 196, de 24 de junho de 1976, do Ministério da Fazenda.

53 De acordo com BORBA, "o aumento do capital da controladora, consequente à incorporação, corresponderá apenas à parcela patrimonial relativa às ações dos não controladores. [...] Assim, todo o sistema de proteção estruturado no art. 264 destina-se ao acionista não controlador da controlada, jamais ao controlador, pois esse é o próprio incorporador, agente do processo de incorporação, não lhe cabendo ação alguma". BORBA, José Edwaldo Tavares. Direito societário. Rio de Janeiro: Freitas Bastos, 1995, p. 442.

54 IUDÍCIBUS, Sérgio de (et. al.). (FIPECAFI) Manual de contabilidade societária da Fundação Instituto de Pesquisas Contábeis, Atuariais e Financeiras. São Paulo: Atlas, 2010, p. 413.

55 GUERREIRO, José Alexandre Tavares; TEIXEIRA, Egberto Lacerda. Das sociedades, op. cit., v. 2, p. 670 . 
Do ponto de vista jurídico, nota-se nas incorporações de companhias controladas uma situação de inevitável conflito, tanto pelos administradores ${ }^{56}$ em comum, que negociarão os termos e as condições da operação de incorporação, como pelo acionista controlador $^{57}$, que votará nas assembleias gerais que deliberarão sobre a incorporação. Nessas hipóteses, deve o Direito Comercial conciliar o princípio majoritário, um dos postulados da Lei das Sociedades Anônimas, com tal situação de conflito, sempre prevendo regras suficientes relativas às avaliações envolvidas.

Não obstante, a Lei das Sociedades Anônimas optou pelo exercício do princípio majoritário nas hipóteses de incorporação de sociedades controladas, mesmo diante da chamada hipótese de self-dealing pelos controladores e seus administradores eleitos. Entretanto, para compensar tamanho poder conferido aos acionistas majoritários, garantiu a lei certos direitos aos minoritários.

56 A despeito do potencial conflito de interesses dos administradores de ambas as sociedades envolvidas na incorporação das companhias controladas, optou a Lei das Sociedades Anônimas por não impor qualquer vedação à sua atuação. Não obstante, a Comissão de Valores Mobiliários publicou o Parecer de Orientação n³5/2008, o qual, apesar das críticas doutrinárias que vem sofrendo desde a sua entrada em vigor, tem como objeto exatamente a regulação da atividade dos administradores em operações dessa natureza. Sobre das críticas ao referido ato normativo, cf. (i) CANTIDIANO, Luiz Leonardo. Incorporação de sociedades e incorporação de ações in CASTRO, Rodrigo R. Monteiro e AZEVEDO, Luiz André, N. de Moura (coord.). Poder de controle e outros temas de direito societário e mercado de capitais. São Paulo: Quartier Latin, 2011, p. 136-158; e (ii) ARAGÃO, Paulo Cezar. O parecer de orientação 35/2008 da CVM e a incorporação de companhias fechada por sua controladora companhia aberta in ADAMEK, Marcelo Vieira Von (coord.). Temas de direito societário e empresarial contemporâneos. São Paulo: Malheiros, 2011, p. 522-534.

57 Sobre o conflito de interesses dos acionistas controladores nas incorporações de sociedades controladas, optou a atual Lei das Sociedades Anônimas por não impor a regra de nulidade do voto do acionista controlador por proibição de voto, nem tampouco pela possibilidade anulação do voto por conflito de interesses, como demandaria a regra geral imposta pelo artigo 115 do mesmo diploma legal. Tal opção deve-se, sobretudo, ao fato de que, caso os controladores fossem impedidos de votar em ambas as assembleias gerais, da sociedade incorporada e da incorporadora que deliberam acerca da incorporação, nunca haveria quórum para aprovar uma incorporação de companhia controlada. Isso porque o artigo 136, IV da Lei das Sociedades Anônimas prescreve que, nas assembléias gerais em que se delibere sobre a incorporação de uma companhia em outra sociedade, "é necessária a aprovação de acionistas que representem metade, no mínimo, das ações com direito a voto, se maior quorum não for exigido pelo estatuto da companhia cujas ações não estejam admitidas à negociação em bolsa ou no mercado de balcão". A respeito, cf. ARAGÃO, Paulo Cezar. O parecer de orientação 35/2008 da CVM e a incorporação de companhias fechada por sua controladora companhia aberta in ADAMEK, Marcelo Vieira Von (coord.). Temas de direito societário e empresarial contemporâneos. São Paulo: Malheiros, 2011, p. 523. 
Nesse sentido, prevê o artigo 264 da Lei das Sociedades por Ações o dever de que os administradores apresentem, junto com o instrumento de protocolo e justificação, o cálculo das relações de substituição das ações dos acionistas não controladores com base na avaliação, de acordo com os mesmo critérios e utilizando-se a mesma data-base, dos patrimônios líquidos das duas sociedades a preços de mercado, ou, no caso de companhias abertas, com base em outro critério aceito pela $\mathrm{CVM}^{58}$.

Concedeu-se aos acionistas, pois, um parâmetro de comparação para a análise da relação de troca que será a eles imposta, e, ao mesmo tempo, ampliou-se o escopo dos trabalhos dos auditores independentes. Conforme abordagem do subcapítulo 4.2.2.5 infra, citamos IUDÍCIBUS (et. al.), segundo o qual,

a consequiência do dispositivo legal comentado no parágrafo anterior é que, em termo práticos, nas combinações envolvendo entidades sob controle comum, sempre existirão dois laudos de avaliação: um para efeito de registro contábil da operação, em que ativos e passivos são avaliados os seus valores de livros; outro para efeito de cálculo das relações de substituição de ações, em que ativos e passivos são avaliados em outra base. ${ }^{59}$

Portanto, uma consequência do disposto no referido artigo 264 é o fato de que, ao contrário das incorporações que não envolvem sociedades controladas ou sob controle comum, deverá nesse caso haver a avaliação da sociedade incorporadora. Entretanto, a despeito de impor a avaliação do patrimônio líquido de ambas as sociedades a preços de mercado a demonstração da relação de substituição com bases em tais avaliações, o referido dispositivo não obriga a que a incorporação seja efetivamente procedida sob tais condições. Ao contrário, o legislador de 1976 manteve para as hipóteses de incorporação

58 “Art. 264. Na incorporação, pela controladora, de companhia controlada, a justificação, apresentada à assembléia-geral da controlada, deverá conter, além das informações previstas nos artigos 224 e 225, o cálculo das relações de substituição das ações dos acionistas não controladores da controlada com base no valor do patrimônio líquido das ações da controladora e da controlada, avaliados os dois patrimônios segundo os mesmos critérios e na mesma data, a preços de mercado, ou com base em outro critério aceito pela Comissão de Valores Mobiliários, no caso de companhias abertas".

59 IUDÍCIBUS, Sérgio de (et. al.). (FIPECAFI) Manual de contabilidade, op. cit., p. 416. 
de sociedade controlada o mesmo regime de liberdade contratual aplicável às demais espécies de incorporação.

Como bem observaram CARVALHOSA e EIZIRIK,

[...] o cálculo da relação de substituição com base no critério do valor do patrimônio líquido a preços de mercado é exigido apenas para fins de comparação com o critério indicado no Protocolo e na Justificação, a fim de evidenciar a equidade da escolha do referido critério.

Nara impede, portanto, que as sociedades envolvidas optem por estabelecer a relação de substituição com base em outro critério, desde que os acionistas sejam informados do cálculo com base no valor patrimonial a preços de mercado. ${ }^{60}$

Tal prescrição mostrou-se extremamente acertada pelo legislador de 1976, que atentou ao fato de que a imposição de um método de cálculo pré-definido para as incorporações de companhias controladas engessaria as relações comerciais ao impor obstáculo insanável para as reorganizações societárias, e, consequentemente, prejudicaria também desenvolvimento econômico (mesmo que justificado por uma nobre tentativa de proteção aos minoritários).

Ora, se por um lado a exigência contábil do artigo 264 da Lei das Sociedades Anônimas não vincula a forma de avaliação e o cálculo da relação de substituição das incorporações de companhias controladas, por outro lado tal simulação serve a outros fins. Em primeiro lugar, serve para que se apresente aos acionistas presentes às assembleias gerais extraordinárias de incorporação uma referência, um parâmetro de comparação sobre as condições de avaliação das sociedades envolvidas e a relação de substituição que está sendo proposta.

Em segundo lugar, serve como referência para a definição do valor de retirada dos acionistas dissidentes da assembleia geral extraordinária da sociedade a ser incorporada. Nessa esteira, dispõe atualmente o $\$ 3^{\circ}$ do art. 264 da Lei das Sociedades Anônimas que,

${ }^{60}$ CARVAlHOSA, Modesto; EIZIRIK, Nelson. A nova lei das S.A. São Paulo: Saraiva, 2002, p. 377. 
Se as relações de substituição das ações dos acionistas não controladores, previstas no protocolo da incorporação, forem menos vantajosas que as resultantes da comparação prevista neste artigo, os acionistas dissidentes da deliberação da assembleia-geral da controlada que aprovar a operação, observado o disposto nos arts. 137, II, e 230, poderão optar entre o valor de reembolso fixado nos termos do art. 45 e o valor do patrimônio líquido a preços de mercado. ${ }^{61}$

O direito previsto no citado dispositivo constitui a única hipótese de exceção à regra do artigo 45 da Lei das Sociedades Anônimas, possibilitando, portanto, o reembolso a um preço calculado de forma alternativa.

Outra questão essencial diz respeito à possibilidade de fixação de um valor de referência diverso do critério dos preços de mercado para a avaliação dos patrimônios líquidos das sociedades envolvidas na incorporação de sociedade controlada, conforme disposto no próprio artigo 264 da Lei das Sociedades Anônimas.

Sobre tal possibilidade, previa a redação original do artigo $264, \S 3^{\circ}$, alínea "a" da Lei das Sociedades Anônimas que, no caso de a relação de substituição prevista no protocolo de incorporação ser menos benéfica que a relação de troca com base na avaliação dos patrimônios líquidos a preços de mercado das companhias envolvidas na incorporação, poderiam os minoritários das companhias abertas incorporadas optar pelo direito de recesso calculado com base no valor da cotação média das ações em bolsa de valores ou no mercado de balcão, durante os trinta dias anteriores à data da assembleia que deliberar sobre a incorporação.

Tal previsão constituía uma alternativa precisa em relação ao critério do patrimônio líquido avaliado a preços de mercado, a ser adotado pelas companhias abertas. Entretanto, prejudicava os acionistas minoritários de companhias abertas com ações de baixa liquidez, pois, nesses casos, a cotação das ações nos últimos trinta dias poderia constituir um parâmetro muito discrepante da realidade.

61 Redação atualizada com as alterações impostas pela Lei 10.303/2001. 
Por tal motivo, em 1997, a Lei 9.457 veio a alterar a redação do parágrafo $3^{\circ}$ do artigo 264 da Lei das Sociedades Anônimas, excluindo a possibilidade de utilização, pelos minoritários dissidentes, do critério alternativo da cotação média das ações durante os trinta dias anteriores à incorporação. Nesse caso, a então nova redação do dispositivo dispôs simplesmente que o exercício do direito de recesso seria possível mediante a utilização do critério da relação de substituição calculada mediante avaliação dos patrimônios líquidos a preços de mercado, ou mediante a regra geral do artigo 45 da Lei das Sociedades Anônimas.

O problema foi que, tanto na sistemática anterior à alteração trazida pela Lei 9.457/97 como na implementada pelo referido diploma legal, haveria dificuldades em relação à avaliação das companhias abertas cujas ações não possuíam liquidez. Dessa forma, a Lei 10.303/2001 tratou de alterar o caput do artigo 264 da Lei das Sociedades Anônimas, possibilitando que a avaliação do patrimônio líquido das sociedades envolvidas e os cálculos da relação de substituição relativos à incorporação de companhias controladas pudessem ser apresentados sob um critério diverso do dos preços de mercado, desde que tal critério diverso fosse aceito pela $\mathrm{CVM}^{62}$.

Um problema vislumbrado com relação à mencionada sistemática atual é o fato de que o parágrafo $3^{\circ}$ do artigo 264 da Lei das Sociedades Anônimas não prevê a possibilidade do direito de retirada do minoritário dissidente segundo cálculo do recesso com base no critério alternativo aprovado pela CVM, mas somente com base na avaliação dos patrimônios líquidos a preços de mercado. Assim, a leitura combinada do parágrafo $3^{\circ}$ do artigo 264 com o seu caput pode levar o intérprete à conclusão de que a comparação da relação de substituição com base em critério aceito pela CVM seria invariavelmente inútil.

Porém, não concordamos com tal interpretação, uma vez que não seria a intenção do legislador a imposição de um dever "em branco", como de fato não o fez. Entendemos mais correto interpretar tais artigos sob a ótica da possibilidade do recesso pelos

62 Sob as formas de avaliação das sociedades para fins de incorporação, cf. subcapítulo 4.2.2.3 adiante. 
minoritários dissidentes com base no critério diverso aceito pela CVM. Em consonância, dispõem CARVALHOSA e EIZIRIK que,

O critério alternativo admitido pela CVM terá como funções apenas aquelas previstas pelo art. 264 da Lei Societária, quais sejam, evidenciar a equidade da relação de troca estabelecida pelos acionistas controladores e determinar o valor de reembolso devido aos acionistas dissidentes na hipótese de as relações de substituição apuradas com base em tal critério alternativo serem mais vantajosas para os acionistas minoritários do que aquelas estabelecidas no Protocolo da incorporação.

Ou seja, os acionistas minoritários somente poderão exigir que o reembolso seja pago com base em tal critério alternativo na hipótese de as relações de substituição apuradas com base no parâmetro indicado no Protocolo da incorporação serem menos vantajosas do que as que resultariam da avaliação realizada de acordo com o critério alternativo. ${ }^{63}$ (grifo nosso)

\subsection{2. $\quad$ Âmbito de aplicação e escopo do artigo 264 da Lei das S.A.}

Outra importante alteração relativa ao tema das incorporações, havida por consequência da promulgação da Lei 10.303/2001, foi a equiparação do tratamento legal das incorporações de companhias controladas às operações de incorporação de companhias sob controle comum e de incorporação da companhia controladora pela a controlada, que é a chamada "incorporação às avessas".

A incorporação da companhia controladora pela companhia controlada, na verdade, já fora analisada pelos próprios coautores da lei do anonimato ${ }^{64}$, e provavelmente escapou do texto legal de 1976 pela impossibilidade de se prever todas as hipóteses no momento da sua elaboração. Tal espécie de incorporação é muito comum quando a sociedade controladora é uma companhia cuja função exclusiva é a de sociedade holding, tendo em vista que a incorporação da sociedade operante controlada ensejaria a necessidade de efetuar registros fiscais e comerciais da controladora (que absorverá as atividades da

\footnotetext{
63 CARVAlHOSA, Modesto; EIZIRIK, Nelson. A nova, op. cit., p. 379.

64 LAMY FILHO, Alfredo; PEDREIRA, José Luiz Bulhões. A Lei, op. cit., p. 592 e ss.
} 
incorporada, como consequência da incorporação), o que demandaria recursos e um tempo precioso numa reorganização societária.

Sobre tal justificativa de ordem prática para se proceder à incorporação da companhia controladora pela sua controlada, dispõem LAMY FILHO e BULHÕES PEDREIRA que,

\begin{abstract}
A sociedade operacional é a mais conhecida no mercado e, quando há interesse em unificar a "holding" e a operacional [...] a incorporação da controladora pela controlada é mais simples porque: a sociedade operacional em geral possui imóveis e outros bens e direitos sujeitos a registro, e a sua incorporação requer formalidades complementares demoradas e custosas [...]. ${ }^{65}$
\end{abstract}

Antes do advento da Lei 10.303/2001, as incorporações de companhia controladora pela sua controlada e aquelas envolvendo companhias sob controle comum foram tratadas como casos em que se permitia a interpretação analógica do artigo 264 da Lei das Sociedades Anônimas, pois ambas envolvem o chamado self-dealing, que é exatamente o fundamento para o tratamento específico da matéria.

Entretanto, havia também interpretação no sentido de que o artigo 264 da Lei das Sociedades Anônimas constitui exceção à regra geral das incorporações e do cálculo do recesso dos minoritários dissidentes, razão pela qual não poderia ser interpretado extensivamente a qualquer hipótese não prevista no referido dispositivo, inclusive às incorporações de companhia controladora pela sua controlada e aquelas envolvendo companhias sob controle comum ${ }^{66}$. Portanto, nota-se que tal equiparação se fazia absolutamente necessária, razão pela qual a alteração imposta pela Lei 10.303/2001 merece celebração.

\footnotetext{
65 LAMY FILHO, Alfredo; PEDREIRA, José Luiz Bulhões. A Lei, op. cit., p. 592 e ss.

66 A respeito, cf. CARVALHOSA, Modesto; EIZIRIK, Nelson. A nova, op. cit., p. 381.
} 
Sobre a interpretação e a aplicabilidade do artigo 264 da Lei das Sociedades Anônimas, aliás, cabe outra importante consideração. Conforme exposto, a ratio de tal dispositivo é a proteção dos acionistas minoritários da sociedade incorporada em relação ao eventual abuso dos acionistas controladores (e, eventualmente, de seus respectivos administradores em comum) nas hipóteses de incorporação de companhia controlada ou sob controle comum. Para essas hipóteses, como visto, o legislador garantiu aos acionistas minoritários (i) uma referência para a avaliação do processo de incorporação, ao impor aos administradores o dever de elaborar uma justificação contendo avaliação de ambas as companhias, incorporadora e incorporada, a preços de mercado, bem como (ii) o direito de recesso sob condições excepcionais, possivelmente mais vantajosas.

Contudo, em algumas hipóteses de incorporação de companhia controlada ou sob controle comum, nota-se a inexistência de uma minoria apta a ter os seus interesses tutelados, como no caso da incorporação de uma companhia subsidiária integral ${ }^{67}$. Em tais hipóteses, a aplicação do artigo 264 da Lei das Sociedades Anônimas, além de ser contrária à sua ratio, implicaria desnecessários e demasiados custos com serviços de avaliação e asseguração bem como um precioso tempo a ser consumido em meio a uma reestruturação societária, razão pela qual a CVM entende como não aplicável o referido dispositivo legal $^{68,69}$.

67 A subsidiária integral constitui rara espécie de sociedade unipessoal permitida pelo Direito Brasileiro, cuja regulação está prevista no artigo 251 da Lei das Sociedades Anônimas. Trata-se, pois, de uma companhia que possui como única acionista uma sociedade brasileira, seja por sua constituição, seja por aquisição total das quotas por um único acionista, seja pela incorporação de suas ações.

68 Cf. Processo CVM RJ 2004/2040, rel. DWB, julgado em 06.04.2004; Processo CVM RJ 2005/3735, rel. SEP, julgado em 28.06.2005; Processo CVM RJ 2005/7838, rel. DNP, julgado em 27.12.2005; Processo CVM RJ 2005/9849, rel. PTE, julgado em 31.01.2006; Processo CVM RJ 2007/2920, rel. SEP, julgado em 17.04.2007; Processo CVM RJ 2007/3465, rel. DEL, julgado em 29.05.2007; Processo CVM RJ 2007/13459, rel. SEP, julgado em 12.11.2007; e Processo CVM RJ 2011/4880, rel. SEP, julgado em 31.05.2001, bem como Deliberação CVM 559/2008, segundo a qual “[...] não se justifica a sua atuação para exigir o cumprimento dos requisitos relacionados no inciso II, nas operações envolvendo companhia aberta relativas à incorporação de controlada por controladora, [...], desde que presentes as seguintes circunstâncias: a) a(s) companhia (s) aberta(s) envolvida(s) não possua $(m)$ dispersão acionária ou acionistas minoritários que necessitem de proteção, nem tampouco qualquer título ou valor mobiliário de sua emissão em circulação; ou b) a companhia aberta seja detentora de $100 \%$ (cem por cento) do capital social da empresa a ser incorporada ou da empresa incorporadora [...]". 
Para tais hipóteses, aliás, a CVM, por meio da Deliberação 559/2008 já manifestou entendimento de que igualmente não se aplicam as imposições de elaboração de demonstrações financeiras auditadas por auditor independente registrado na CVM, nos

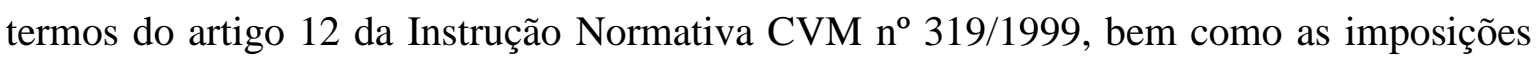
de publicação, na imprensa, do Fato Relevante tratado no artigo $2^{\circ}$ da Instrução Normativa $\mathrm{CVM} \mathrm{n}^{\circ} 319 / 1999$.

Bem verdade que tal operação poderia ser considerada prejudicial aos acionistas da própria sociedade incorporadora na hipótese de a companhia subsidiária integral possuir um patrimônio líquido negativo, já que a consequência natural da incorporação seria a redução do patrimônio líquido da sociedade incorporadora ou até mesmo a compensação do patrimônio líquido negativo da sociedade incorporada com eventuais lucros ou reservas da sociedade incorporadora, o que implicaria a redução da base de cálculo dos dividendos.

Entretanto, tal prejuízo aos acionistas minoritários da sociedade incorporadora não justificaria o pleito, pelos acionistas minoritários, em favor da aplicabilidade do artigo 264 da Lei das Sociedades Anônimas, pois, como visto, tal dispositivo visa a tutelar exclusivamente os interesses dos acionistas minoritários da sociedade incorporada. Tanto o é que o parágrafo $3^{\circ}$ desse artigo 264 não prevê direito de recesso sob condições especiais aos acionistas da sociedade incorporadora.

Abordados brevemente os principais aspectos das incorporações, serão analisadas, a seguir, as características, os deveres gerais e as peculiaridades relativas à atuação dos auditores independentes nas referidas operações.

69 Por outro lado, verificou-se no Processo CVM RJ 2004/5914, rel. SEP, julgado em 31.01.2004, imposição, pela CVM, da elaboração do laudo de avaliação a preços de mercado quando existir minoritários cujos direitos deverão ser tutelados. 


\section{ESCOPO, ÂMBITO DE ATUAÇÃO E FUNÇÃO DAS ATIVIDADES DESENVOLVIDAS PELOS AUDITORES INDEPENDENTES}

\subsection{Da relação jurídica entre os auditores independentes e as companhias}

A fim de tratar das atividades desenvolvidas pelos auditores independentes, cabe, em primeiro lugar, definir a natureza da relação jurídica existente entre tais agentes e a companhia que o contrata.

Nesse sentido, nota-se que a independência que os auditores devem ter em relação às companhias auditadas sugere que aqueles devem ser considerados meros terceiros contratados para a prestação de serviços de auditoria independente, avaliação de empresas, dentre outros. Tal contratação é, em regra, formalizada pela celebração de um contrato de prestação de serviços ou uma simples aceitação, pela companhia, de uma proposta de honorários, instrumentos que servirão para fixar determinados termos que regularão a prestação de serviços entre os auditores e a companhia e, como consequência, serviriam para sustentar a existência de uma relação contratual entre ambos.

Há, entretanto, algumas características inerentes às atividades dos auditores independentes que podem indicar uma ampliação da definição da sua relação jurídica com a companhia. Em primeiro lugar, conforme será abordado no Capítulo 4 adiante, as atividades dos auditores independentes são reguladas não somente pelos termos e condições do contrato de prestação de serviços ou da proposta de honorários, mas também por diversas leis, atos normativos, e normas de auto-regulação que garantem qualidade e padrões de prestação de serviços e, mais importante, preveem deveres gerais e específicos de atuação inerentes à condição de auditor independente.

Ademais, o interesse público inerente às atividades desenvolvidas pelos auditores independentes e o grau de proximidade e conhecimento das atividades sociais que possuem 
são elementos que corroboram para a existência de uma relação jurídica que extrapola a mera relação contratual.

Nos EUA, após os escândalos contábeis da Enron e WorldCom, dentre outras companhias abertas, e com a promulgação do Sarbanes-Oxley Act, mudou-se a concepção tradicional sobre os auditores independentes. Deu-se destaque ao papel desenvolvido pelos profissionais responsáveis pela elaboração, verificação ou certificação das informações prestadas pelas companhias ao mercado (gatekeepers), chegando-se a afirmar que a denominada teoria da Agência também se aplica a tais profissionais ${ }^{70}$.

Por tais motivos, entendemos possível sustentar a existência de uma relação jurídica especial entre os auditores independentes e as companhias que utilizam os seus serviços, construção que será a base para o entendimento de uma responsabilidade legal dos auditores independentes, conforme abordagem do subcapítulo 5.2 adiante.

\subsection{Escopo dos trabalhos e âmbito de atuação dos auditores independentes}

Estudada a relação dos auditores independentes com as companhias participantes de uma incorporação, serão definidos neste subcapítulo o escopo dos trabalhos desenvolvidos e o âmbito de atuação de tais agentes em operações dessa natureza.

Em relação ao escopo dos trabalhos desenvolvidos pelos auditores independentes, entende-se que o escopo principal de seus trabalhos e, como consequência, a principal atividade por eles desenvolvida em operações societárias é a revisão das demonstrações financeiras da companhia auditada ${ }^{71}$, entre as quais estão incluídas (i) o balanço

70 Conforme KLEIN, COFFEE JR. e PARTNOY, "but the basic point that the concept of the agency costs applies not only to a corporation's managers and employees, but also to its outside agents". KLEIN, William A.; COFFEE JR., John C.; PARTNOY, Frank. Business organization and finance - legal and economic principles. New York: Foundation Press, 2010, p.184.

71 Cf. (i) LEÃES, Luiz Gastão Paes de Barros. Pareceres. São Paulo: Singular, 2004, p. 603-604; (ii) Poder de polícia da CVM frente aos auditores independentes. Revista de Direito Administrativo, n. 193, p. 384, Rio de Janeiro: Renovar, jul/set. 1993; e (iii) ALMEIDA, Bruno José Machado de; COLIMINA, Clara 
patrimonial, (ii) as demonstração dos lucros ou prejuízos acumulados, (iii) a demonstração do resultado do exercício, (iv) a demonstração dos fluxos de caixa, e (v) a demonstração do valor adicionado, esta no caso de companhia aberta $^{72}$.

Entretanto, o elevado grau de qualificação contábil e a vasta experiência em grandes operações possuídas pelas empresas de auditoria, somados à flexibilização das normas sobre a prestação dos chamados non-audit services, justificam a prestação de serviços muito mais amplos por tais agentes nas operações de incorporação, sobretudo nas incorporações envolvendo companhias abertas.

Como consequência, destacamos os seguintes principais serviços tipicamente desenvolvidos pelos auditores independentes numa operação de incorporação, os quais estão inseridos, pois, nas fases 1 e 2, conforme definidas no subcapítulo 2.2 acima:

a) revisão de demonstrações financeiras, com a consequente emissão de um parecer técnico;

b) avaliação da sociedade incorporada e de seus ativos;

c) participação nas assembleias gerais de incorporação;

d) consultoria e planejamento societário e fiscal da operação; e

e) revisão e emissão de parecer sobre o processo de incorporação como um todo.

Em relação às incorporações envolvendo companhias controladas ou sob controle comum, o escopo da atuação dos auditores independentes é aumentado, uma vez que poderão ser responsáveis por proceder a uma segunda avaliação da companhia incorporadora e da incorporada, a fim de definir a relação de substituição com base nos patrimônios líquidos avaliados a preços de mercado, ou outro critério aprovado pela CVM.

Isabel Muñoz. Evidencia de las diferencias de expectativas en auditoria en mercados bursátiles de la reducida dimensión: el caso Portugués. Revista Contabilidade \& Finanças, São Paulo, v. XIX, n. 47, mai./ago. 2008.

72 Conforme o artigo 176 da Lei das Sociedades Anônimas. 
Nas companhias fechadas tal avaliação poderá ser feita pelos auditores independentes como alternativa à contratação de três peritos, e, nas companhias abertas tal avaliação deverá ser feita necessariamente por empresa especializada ${ }^{73}$, geralmente os próprios auditores independentes. Em tal hipótese específica de incorporação de companhia controlada, ademais, a avaliação dos auditores independentes terá maior importância, pois servirá como base para o exercício do direito de retirada pelos minoritários dissidentes da companhia incorporada.

Entretanto, nos casos de subsidiárias integrais com ausência de dispersão acionária das companhias envolvidas na operação de incorporação, mesmo quando tal operação envolver companhias abertas, a atuação dos auditores independentes será reduzida, pois é dispensada a elaboração de demonstrações financeiras auditadas e de avaliação do patrimônio líquido das companhias envolvidas a preços de mercado.

Note-se, portanto, que a atuação dos auditores independentes é de grande importância no processo de incorporação entre companhias, uma vez que impactará (i) na relação de substituição de ações, (ii) na avaliação das sociedades incorporadas, (iii) na análise dos acionistas quando da deliberação da operação de incorporação, e possivelmente, como consequência, (iv) no desfecho da assembleia geral, e no direito de retirada dos acionistas dissidentes. Dessa forma, a definição dos deveres e responsabilidades dos auditores independentes mostra-se fundamental para a tutela dos interesses dos acionistas e do mercado.

Já quanto ao âmbito de atuação, note-se que o parágrafo $3^{\circ}$ do artigo 177 da Lei das Sociedades Anônimas dispõe que as companhias abertas estão obrigadas a contratar auditores independentes devidamente registrados na CVM para a revisão das suas

73 Conforme o parágrafo $1^{\circ}$ do artigo 264 da Lei das Sociedades Anônimas. 
demonstrações financeiras ${ }^{74}$. De forma complementar, a Instrução Normativa CVM n ${ }^{\circ}$ 319/1999, em seu artigo 12, determina que as demonstrações financeiras que servirem como base para quaisquer operações de incorporação, fusão ou cisão envolvendo companhia aberta deverão ser auditadas por auditores independentes devidamente registrados na $\mathrm{CVM}$, mesmo se tais demonstrações financeiras se referirem às contas de uma companhia fechada ${ }^{75}$ ou mesmo de uma entidade de tipo societário diverso.

Ademais, o artigo $3^{\text {o76 }}$ da Lei 11.638 , de 28 de dezembro de 2007 determina que as sociedades de grande porte também estão obrigadas à contratação de auditor independente devidamente registrado na CVM para fins de auditoria das suas demonstrações contábeis. Tal norma aumentou o âmbito de atuação desses agentes em relação aos tipos societários diversos das sociedades anônimas, já que o parágrafo único do mesmo dispositivo legal define as sociedades de grande porte como aquelas que tenham apurado no exercício social anterior, individualmente ou em conjunto com outras sociedades sob controle comum, ativo total superior a $\mathrm{R} \$ 240.000 .000,00$ ou receita bruta anual superior a $\mathrm{R} \$ 300.000 .000,00$.

Sem prejuízo, quaisquer outras sociedades que não estejam obrigadas à contratação de auditores independentes para a revisão das suas demonstrações financeiras poderão fazê-lo por opção, para dar maior credibilidade à demonstração dos seus resultados apurados.

74 “As demonstrações financeiras das companhias abertas observarão, ainda, as normas expedidas pela Comissão de Valores Mobiliários e serão obrigatoriamente submetidas a auditoria por auditores independentes nela registrados."

75 Em alguns casos, entretanto, o colegiado da CVM entendeu possível a dispensa de auditoria nas demonstrações financeiras das companhias incorporadas quando se tratar de companhia fechada e subsidiária integral, uma vez que, nesses casos, as demonstrações financeiras da companhia aberta incorporadora devem ser elaboradas de forma consolidada e utilizando-se o método da equivalência patrimonial em relação à participação integral na companhia incorporada. A respeito, cf. Processo CVM RJ 2007/13459, rel. SEP, julgado em 12.11.2007; Processo RJ 2005/7750, rel. SEP, julgado em 09.11.2005; e Processo CVM RJ 2005/3735, rel. SEP, julgado em 28.06.2005.

76 “Aplicam-se às sociedades de grande porte, ainda que não constituídas sob a forma de sociedades por ações, as disposições da Lei $n^{\circ}$ 6.404, de 15 de dezembro de 1976, sobre escrituração e elaboração de demonstrações financeiras e a obrigatoriedade de auditoria independente por auditor registrado na Comissão de Valores Mobiliários." 
Em relação às demais atividades desenvolvidas pelos auditores independentes nas operações de incorporação, a liberdade para a sua contratação é ainda maior, tendo em vista que não há imposição legal para a sua escolha como prestadores de serviços. Em relação à atividade de avaliação da companhia incorporada, a Lei das Sociedades Anônimas não define de forma específica os conceitos de "perito" e "empresa especializada" a que se refere o seu artigo $8^{\circ}$, desobrigando as companhias da contratação de um auditor independente como perito.

Não obstante tal ausência de imposição legal, o elevado grau de confiabilidade e especialização dos auditores independentes resulta na sua contratação, na qualidade de avaliadores, para atuar em quase todas as operações de incorporação envolvendo companhias abertas, de forma que atividades diversas da de asseguração são prestadas por tais agentes nas operações dessa natureza. Por tal motivo, o Instituto dos Auditores Independentes do Brasil (IBRACON) publicou, em 24 de setembro de 2007, a norma NPA 14, que dispõe sobre os "laudos de avaliação emitidos por auditor independente", a qual será estudada no subcapítulo 4.2.2 adiante.

O presente estudo, por opção metodológica, restringe-se às operações de incorporação envolvendo companhias abertas. Sob tal premissa, abordar-se-á, a seguir, a função das atividades desenvolvidas pelos auditores independentes para, mais adiante, discorrer pormenorizadamente sobre as atividades destes profissionais numa operação de incorporação, enfatizando-se os trabalhos de revisão de demonstrações financeiras da sociedade incorporada e de avaliação do seu patrimônio liquido a ser vertido à sociedade incorporadora.

\subsection{Funções dos trabalhos desenvolvidos pelos auditores independentes}

Ao realizar as atividades anteriormente referidas, os auditores independentes cumprem funções internas e externas às companhias que os contratam, aos seus acionistas e às operações de incorporação em si. 
A função interna diz respeito à fixação e ratificação dos números constantes nas demonstrações financeiras e na avaliação da companhia incorporada, concedendo aos sócios parte dos subsídios necessários para a tomada de decisões quanto à operação de incorporação, seja em relação à aprovação ou não da operação, seja em relação ao exercício do direito de retirada.

Já a função externa diz respeito aos interesses dos investidores e do mercado de capitais como um todo, servindo o trabalho desenvolvido pelos auditores independentes para certificar os números envolvidos e passar credibilidade quanto à operação de incorporação, sinalizando ao mercado o uso das melhores práticas contábeis e financeiras.

Há, portanto, grande interesse público em que sejam reguladas as atividades praticadas pelos auditores independentes, uma vez que tais atividades influem diretamente na simetria de informações disponibilizadas aos participantes do mercado de capitais, sendo esse um requisito para a criação de um mercado eficiente ${ }^{77}$ para a negociação de valores mobiliários ${ }^{78}$. Nessa esteira, o Capítulo seguinte servirá para analisar os deveres gerais e específicos desses agentes quando da prestação de serviços nas hipóteses de incorporações envolvendo companhias abertas.

77 CARVALHOSA, Modesto; EIZIRIK, Nelson. A nova, op. cit., p. 544.

78 Sobre a importância do controle da assimetria de informações para o funcionamento regular dos mercados, cf. AKERLOFF, G. The Market for Lemons: Quality Uncertainty and the Market Mechanism. Quarterly Journal of Economics. v. 84, n. 3, ago. 1970. 


\section{DA ATUAÇÃO DOS AUDITORES INDEPENDENTES NAS OPERAÇÕES DE INCORPORAÇÃO}

\subsection{Deveres gerais e pressupostos de atuação dos auditores independentes}

Após a definição do âmbito de atuação e do escopo dos trabalhos dos auditores independentes nas operações de incorporação e antes de serem analisados os deveres específicos dos auditores independentes em tais operações, faz-se necessário discorrer sobre os deveres gerais de conduta a eles impostos, quais sejam os deveres de objetividade e independência, sigilo, lealdade e competência profissional.

A princípio, tais deveres gerais foram previstos no Statements on Management Accounting ${ }^{79}$, pioneiro código de ética surgido da autorregulação contábil norte-americana, expedido em 1982 pelo Institute of Management Accountants, e que serviu como referência internacional desde a sua expedição. Modernamente, o Código de Ética Profissional da International Federation of Accountants (IFAC) define os referidos deveres gerais $^{80}$, fato que reforça a sua aplicabilidade internacional, já que atualmente se verificam esforços de diversos países para a adoção das regras emanadas por tal órgão como uma tentativa de convergência sobre o tratamento e os padrões contábeis nos diferentes ordenamentos jurídicos ${ }^{81}$.

INSTITUTE OF MANAGEMENT ACCOUNTANTS. Statements on management accounting: objectives of management accounting - Statement 1B. New York, 1982.

80 INTERNATIONAL FEDERATION OF ACCOUNTANTS. Code of Ethics for Professional Accountants, June 2005, rev. July 2006, p. 1103 a 1115 . Disponível em: $\langle$ http://www.ifac.org/sites/default/files/publications/files/ifac-code-of-ethics-for.pdf $>$. Acesso em: 22 jan. 2012.

81 No Brasil, por exemplo, o Instituto dos Auditores Independentes do Brasil (IBRACON) atualmente desenvolve conjuntamente com o Conselho Federal de Contabilidade o trabalho de tradução e revisão das normas internacionais de auditoria emitidas pela IFAC, mediante aprovação e emissão pelo Conselho Federal do Contabilidade. Tais normas são constantemente analisadas pelo Comitê de Pronunciamentos Contábeis (CPC) e os consequentes Pronunciamentos Técnicos e as Interpretações Técnicas são aprovados pela CVM por meio de Deliberações. 
No direito continental europeu, o artigo 21 da Diretiva Europeia 2006/43/EC é claro ao dispor sobre tais deveres ${ }^{82}$. Já em nosso ordenamento jurídico, conforme será abordado, tais deveres estão implícitos no Código de Ética Profissional do Contador, aprovado pela Resolução 803/96 do Conselho Federal de Contabilidade (CFC), explícitos nos diversos atos normativos recentemente expedidos pelo $\mathrm{CFC}^{83}$ e são referendados pela doutrina ${ }^{84}$.

\subsubsection{A objetividade e a independência}

Os primeiros deveres gerais impostos aos auditores independentes são o dever de objetividade e independência. $\mathrm{O}$ dever de objetividade significa o controle das atividades dos auditores independentes para que sejam desenvolvidas de forma objetiva e imparcial em relação ao seu cliente e ao mercado, livre de quaisquer influencias externas que possam comprometer o seu julgamento. Nesse sentido, o item 120.1 do Código de Ética Profissional da IFAC dispõe que "the principle of objectivity imposes an obligation on all professional accountants not to compromise their professional or business judgment because of bias, conflict of interest or the undue influence of others" ${ }^{\prime 25}$.

82 "1. Member States shall ensure that all statutory auditors and audit firms are subject to principles of professional ethics, covering at least their public-interest function, their integrity and objectivity and their professional competence and due care.

2. In order to ensure confidence in the audit function and to ensure uniform application of paragraph 1 of this Article, the Commission may, in accordance with the procedure referred to in Article 48(2), adopt principle-based implementing measures governing professional ethics" (grifo nosso).

83 Cf. NBC PA 01e NBC TA 200, dentre outros.

84 Cf. (i) LONGO, Claudio Gonçalo. (FIPECAFI) Manual de auditoria e revisão de demonstrações financeiras. 2. ed. São Paulo: Atlas, 2011, p. 52; e (ii) LISBOA, Lázaro Plácido. Ética geral e profissional em contabilidade. 2. ed. São Paulo: Atlas, 2011, p. 69-70.

85 INTERNATIONAL FEDERATION OF ACCOUNTANTS. Code of Ethics for Professional Accountants, June 2005, rev. July 2006, p. 1103 a 1115 . Disponível em: <http://www.ifac.org/sites/default/files/publications/files/ifac-code-of-ethics-for.pdf >. Acesso em: 22 jan. 2013. 
Nota-se, portanto, que a objetividade dos trabalhos desenvolvidos pelos auditores independentes é uma consequência da observância, por tais agentes, de determinadas regras que garantem a sua independência em relação aos seus clientes e ao mercado como um todo. Trata-se de padrões de comportamento inter-relacionados, já que ambos se referem ao controle da imparcialidade dos trabalhos dos auditores independentes, característica que, embora deva ser entendida como o principal dever geral imposto a esses agentes $^{86}$, muitas vezes não é por eles observada em suas atividades, sobretudos naquelas desenvolvidas no âmbito de uma operação de incorporação.

Conforme abordagem do subcapítulo 3.2 anterior, os trabalhos desenvolvidos pelos auditores independentes numa operação de incorporação, via de regra, transcendem o objeto principal deles esperado, qual seja o de emissão de parecer técnico sobre a adequação das demonstrações financeiras das companhias à sua real situação financeira e aos requisitos legais aplicáveis e princípios contábeis adequados. Diante de tal cenário, há de se pensar até que ponto a atuação diversificada dos auditores nessas operações impacta diretamente a sua independência como prestadores de serviços de revisão ${ }^{87}$.

Para melhor abordar tal problemática, deve-se identificar a que se refere o conceito de "independência" a que os auditores independentes estão vinculados. Trata-se de independência em relação à companhia ou entre as próprias atividades a serem prestadas?

86 Item 6 da nota explicativa à instrução CVM no 308/99.

87 A premissa para tal indagação surge do fato de que, analisando a questão do ponto de vista sociológico, há que se pensar que a diversidade de serviços contratados pela companhia e a perspectiva de contratação futura para estes e outros variados serviços poderia implicar uma verdadeira "coação branca" sobre a atividade dos auditores independentes, profissionais que, paralelamente ao dever de independência, exercem suas atividades visando lucro (para utilizar a expressão de GUERREIRO ao analisar assunto diverso, o da sociologia do poder nas sociedades anônimas brasileiras. Cf. GUERREIRO, José Alexandre Tavares. Sociologia do poder na sociedade anônima. Revista de Direito Mercantil Industrial, Econômico e Financeiro, ano XXIX, n. 77, p. 52). Conforme EISENBERG, "the pressure on the accountants to go along in marginal (an even less-than-marginal) cases is considerably augmented by the fact that if an incumbent accountant does balk, a more flexible auditor can almost always be found. The result is that an accountant who uses or threatens to use his only real control over management's selection of accounting principles is likely to lose corporation's financial statements. Many accountants appear to regard the withholding of a clean opinion under such circumstances as a quixotic gesture".EISENBERG, Melvin Aron. The structure of the corporation. Washinton: Beard Books, 2006, p. 197-198. 
O Código de Ética Profissional do Contador, aprovado pela Resolução 803/96 do CFC, contém diversas proposições acerca da independência dos auditores independentes como profissionais de contabilidade, a maioria delas dizendo respeito à situação de conflito pelos auditores. Sem especificar, entretanto, o conceito de conflito, destacamos o artigo $5^{\circ}$ do referido diploma, segundo o qual

O Contador, quando perito, assistente técnico, auditor ou árbitro, deverá: [...]

II - abster-se de interpretações tendenciosas sobre a matéria que constitui objeto de perícia, mantendo absoluta independência moral e técnica na elaboração do respectivo laudo;

[...]

IV - considerar com imparcialidade o pensamento exposto em laudo submetido à sua apreciação;

[...]

VIII - considerar-se impedido para emitir parecer ou elaborar laudos sobre peças contábeis, observando as restrições contidas nas Normas Brasileiras de Contabilidade emitidas pelo Conselho Federal de Contabilidade;

De acordo com o item 6 da norma NBC PA 290, aprovada pela Resolução 1.311/10 do CFC, a qual trata da independência dos trabalhos de auditoria e revisão, o conceito de independência compreende a independência de pensamento e a aparência de independência, conforme definições a seguir:

Independência de pensamento: postura que permite a apresentação de conclusão que não sofra efeitos de influências que comprometam o julgamento profissional, permitindo que a pessoa atue com integridade, objetividade e ceticismo profissional.

Aparência de independência: evitar fatos e circunstâncias que sejam tão significativos a ponto de que um terceiro com experiência, conhecimento e bom senso provavelmente concluiria, ponderando todos os fatos e circunstâncias específicas, que a integridade, a objetividade ou o ceticismo profissional da firma, ou de membro da equipe de auditoria ficaram comprometidos. 
Ademais, outras normas editadas pelo CFC como NBC TA $200^{88}$, aprovada pela Resolução CFC 1.203/09, e a NBC PA $01^{89}$, aprovada pela Resolução CFC 1.201/09, do mesmo modo dispõem sobre a independência dos auditores independentes como dever e pressuposto de atuação.

Independência dos auditores, portanto, significa a ausência de quaisquer interesses e condições capazes de afetar positiva ou negativamente nas atividades de revisão das demonstrações financeiras desenvolvidas e, mais do que isso, a ausência de qualquer situação ou fato que comprometa a aparência de inexistência de tais interesses e condições $^{90}$. Conforme item A.16 da NBC TA 200,

\begin{abstract}
A independência do auditor frente à entidade salvaguarda a capacidade do auditor de formar opinião de auditoria sem ser afetado por influências que poderiam comprometer essa opinião. A independência aprimora a capacidade do auditor de atuar com integridade, ser objetivo e manter postura de ceticismo profissional.
\end{abstract}

Nesse sentido, pode-se entender que o ideal almejado por tais prestadores deve ser tanto a independência dos auditores independentes (ou de seus representantes, no caso de auditores enquanto pessoas jurídicas) em relação à companhia e aos seus empregados, representantes e sócios, como a independência do serviço de auditoria independente em relação aos demais serviços prestados, contábeis ou não.

Diante de tais conceitos, após as quebras de grandes grupos econômicos em meados de 1998, como nos famosos casos Enron e Worldcom, relacionadas a escândalos envolvendo fraudes contábeis com a participação de auditores independentes cuja

88 Cf. itens A14 a A17.

89 Cf. itens A7 a A10.

90 Por tal motivo, o artigo $4^{\circ}$ da Diretiva Europeia 2006/43/EC dispõe que "the competent authorities of a Member State may Grant approval only to natural persons or firms of good repute". O inciso IV do artigo 15 da Instrução CVM n ${ }^{\circ} 308 / 99$, por sua vez, prevê como causa para a suspensão ou cancelamento automático do registro de auditor independente a condenação, por sentença judicial transitada em julgado, em processo-crime de natureza infamante, ou por crime ou contravenção de conteúdo econômico, bem como o impedimento para o exercício de cargo público. 
independência mostrava-se comprometida, os diversos ordenamentos jurídicos passaram a dar especial atenção à questão da independência dos auditores.

Entre as medidas percebidas, ressaltam-se (i) a imposição de um sistema de rotatividade relativo aos trabalhos de auditoria independente, (ii) a proibição de prestação concomitante de serviços diversos daqueles de revisão de demonstrações financeiras, i.e., dos non-audit services, e (iii) a imposição de outras regras de conflito de interesse.

Sobre a primeira medida, em 14 de maio de 1999, a CVM editou a Instrução Normativa $\mathrm{n}^{\circ} 308$, a qual previu a rotatividade dos auditores independentes entre si em relação a seus clientes de auditoria. Dispõe o artigo 31 do referido ato normativo que os auditores independentes não podem prestar serviços para um mesmo cliente por prazo superior a cinco anos consecutivos, contados a partir da data da referida instrução ${ }^{91}$, exigindo-se um intervalo mínimo de três anos para a sua recontratação ${ }^{92}$.

Evidentemente, tal imposição foi alvo de diversas críticas por parte das grandes empresas de auditoria e de algumas entidades de classe, tendo em vista que, além de interferir nos interesses de tais agentes, é questionável do ponto de vista da alteração da qualidade e preço dos serviços de auditoria ${ }^{93,94}$.

91 A respeito da necessidade de um período de adaptação, a CVM publicou a Deliberação $\mathrm{n}^{\circ}$ 549/08, alterada pela Deliberação CVM no 669/11, facultando às companhias abertas que substituam seus auditores independentes somente após o encerramento das demonstrações financeiras do exercício social de 2011.

92 A Instrução CVM n ${ }^{\circ}$ 509/11, entretanto, estendeu de cinco para dez anos consecutivos o limite temporal de prestação de serviços pelos auditores independentes às companhias abertas, desde que tais companhias possuam um Comitê de Auditoria Estatutário e que o auditor seja uma pessoa jurídica. Caso as companhias optem por tal faculdade, os auditores deverão, após cinco anos de prestação de serviço, efetuar a troca do responsável técnico e dos demais profissionais envolvidos na auditoria independente, os quais não poderão ser envolvidos nos trabalhos referentes à tais companhias antes de três anos após a substituição. Sobre a rotatividade dos profissionais de empresa de auditoria independente que prestam serviços por tempo prolongado aos clientes, cf. também os itens 150 e 155 da NBC PA 290, aprovada pela Resolução CFC 1.311/10.

93 Cf. SARAIVA, Luciana de Pontes. Governança Corporativa e auditores independentes: uma visão de Sarbanes-Oxley Act e da Regulamentação da Comissão de Valores Mobiliários in: CANTIDIANO, Luiz Leonardo. Governança Corporativa: empresas transparentes na sociedade de capitais. São Paulo: Lazuli, 2004, p. 137-138. 
94 A respeito das vantagens e desvantagens da regra de rotatividade dos auditores independentes, cf. MEMO CVM/SNC/GNA/ ${ }^{\circ}$ 073/05, no qual elencaram-se as seguintes:

Vantagens do Rodízio de Auditores Independentes:

a) na visão do público externo, propicia uma percepção de reforço adicional da independência e da credibilidade dos profissionais da área de auditoria, no que tange ao seu relacionamento com os executivos e demais profissionais da companhia auditada;

b) propicia maior ceticismo e objetividade do auditor independente na execução dos trabalhos, em função da própria limitação do prazo de relacionamento com a companhia auditada, evitando que o contrário, ou seja, o longo relacionamento acarrete um certo relaxamento e excesso de confiança da parte do auditor sobre os controles internos e demais informações econômico-financeiras da companhia auditada;

c) pode favorecer uma transferência de conhecimento técnico de um auditor para outro, na medida em que firmas de auditoria possam ter experiências no desenvolvimento de práticas de auditoria em segmentos de mercado ainda não auditados por elas mesmas, contribuindo, no médio e longo prazo, para o aumento da competição nesse mercado;

d) proporciona uma crítica interna na estrutura e na forma de atuação das empresas de auditoria no tocante a sua metodologia e abordagens adotadas na execução dos trabalhos;

e) propicia uma nova visão sobre os controles internos da companhia auditada, aumentando a possibilidade de identificação de riscos e problemas que ainda não haviam sido questionados; $\mathrm{e}$

f) a troca da firma de auditoria, e não a simples rotação de seu pessoal no atendimento a determinado cliente, dificulta a formação de conluios para consecução de fraudes e conivência em atos ilícitos tenham continuidade.

Desvantagens do Rodízio de Auditores Independentes:

a) a qualidade do trabalho do auditor independente atinge seu melhor padrão após um tempo considerável de conhecimento do ambiente, da estrutura e das atividades da companhia auditada (curva de aprendizagem), geralmente de dois a três anos de relacionamento, o que, para os anos subseqüentes, proporciona maiores benefícios na execução dos trabalhos. O rodízio limita a geração desses benefícios;

b) o rodízio aumenta a probabilidade de mudança de atitude entre o auditor independente e a companhia auditada, na medida em que o prazo máximo da relação é estabelecido. Os auditores poderão no último ano de relacionamento dirigir seus esforços para a conquista de novos clientes, diminuindo a atenção dispensada ao cliente atual, enquanto que a companhia auditada poderá priorizar mais o quesito remuneração, em vez da qualidade da prestação do serviço de auditoria;

c) tendo em vista a certeza do prazo de relacionamento entre o auditor e a companhia auditada, poderá ocorrer um prejuízo no planejamento de médio e longo prazo, considerando uma possível perda de investimento na qualificação dos profissionais das firmas de auditoria, referente ao treinamento oferecido na formação de especialistas na atuação em determinados segmentos;

d) o rodízio obrigatório de auditores elimina a prerrogativa da administração da empresa (companhia auditada) de decidir se deseja ou não continuar o relacionamento com seus auditores independentes (limitação da liberdade de escolha);

e) empresas que possuem filiais em outros países ou que são filiais de alguma empresa multinacional, e que gostariam de manter uma unidade com relação aos auditores (uma firma de auditoria responsável pela auditoria de todas as empresas do grupo), poderiam perder essa conveniência;

f) a qualidade dos trabalhos poderá ser impactada em função da redução da relação entre as partes e da perda do conhecimento acumulado, restringindo a capacidade de crítica e de análise de procedimentos ou planejamento dos trabalhos;

g) acirramento da concorrência entre as firmas de auditoria, com redução dos honorários profissionais, podendo gerar grave risco à qualidade dos trabalhos; $\mathrm{e}$

h) probabilidade maior de ocorrência de erros e fraudes nos primeiros anos de relacionamento entre o auditor e a companhia auditada, em função da falta de conhecimento da estrutura dos controles internos e da própria cultura corporativa, e de aumento de custos, tanto do auditado quanto do auditor, pelo maior número de horas que deverão ser empregados para o conhecimento mútuo. 
Não por coincidência, o artigo 31 da Instrução Normativa CVM no $31 / 99$ foi objeto de uma ação direta de inconstitucionalidade ${ }^{95}$ interposta pela Confederação Nacional do Comércio, sob o argumento de que a regra da rotatividade viola os princípios constitucionais do trabalho e da livre iniciativa (art. $1^{\circ}$, IV e art. 170, caput), livre exercício profissional (art. $5^{\circ}$ XIII), livre concorrência (art. 170, IV), e livre exercício da atividade (art. 170, parágrafo único), bem como viola o próprio princípio da legalidade, uma vez que impõe obrigação não prevista em lei ${ }^{96}$.

Ainda, argumentou a proponente sobre um risco moral que implicaria um efeito contrário ao que pretendido com a imposição da norma, conforme a seguir:

E, em vez de elevar o nível de confiabilidade das auditorias - objetivo alegadamente visado pela norma impugnada -, a rotatividade do art. 31 arrisca produzir, a longo prazo, o efeito contrário: reduzida a concorrência, os profissionais e empresas de auditoria independente tenderão a se acomodar, relaxando na busca do aprimoramento dos seus serviços e exigindo da CVM uma vigilância cada vez maior. Mitigando a competição em benefício dos menos capacitados, a regra da "rotatividade" produziria esse resultado em qualquer segmento da atividade econômica ao qual fosse aplicada. ${ }^{97}$

Até o momento o referido pleito não havia sido julgado em definitivo ${ }^{98}$, e, consequentemente, o artigo 31 da Instrução Normativa CVM n 308/99 não só permanece

95 STF ADI no 3033-7/RJ, rel. Min Cesar Peluso, aguardando julgamento.

96 Conforme petição inicial protocolada pela Confederação Nacional do Comércio quando da imposição da ADI n' 3033-7, p. 6-7.

97 Ibidem, p. 4.

98 Não obstante, o Supremo Tribunal Federal já havia se manifestado sobre o mesmo tema ao julgar a ADI 2.317-9/DF, rel. Min. Ilmar Galvão, proposta pela Confederação Nacional das Profissões Liberais em vista da já revogada Resolução 2.267/96 do Conselho Monetário Nacional, a qual, em seu artigo $3^{\circ}$ dispunha que "as instituições e entidades referidas no art. $1^{\circ}$, bem como as administradoras de fundos de investimentos ali mencionadas e de consórcio, devem proceder à substituição de auditor independente contratado no máximo após decorridos 4 (quatro) exercícios sociais completos desde sua contratação, vigorando essa exigência a partir do exercício social que se iniciar em $1^{\circ}$ de janeiro de 1997'. Naquele pleito, o relator, Ministro Ilmar Galvão, entendeu que "a medida expressa na resolução atacada visa à manutenção, exatamente, da necessária autonomia dos auditores independentes, cuja permanência por longos períodos junto à mesma instituição poderia comprometer a eficácia do controle exercido pelo Banco Central'. Em favor da constitucionalidade e dos benefícios da referida regra de rotatividade dos auditores independentes, cf. VERÇOSA, Haroldo Malheiros Duclerc. Conselho Monetário Nacional. 
em vigor, como a CVM tem respondido a consultas em favor da sua aplicação ${ }^{99}$, bem como investigado e punido os auditores independentes que não respeitam a regra da rotatividade $^{100}$. Após consulta do IBRACON, em 19 de setembro de 2003 o colegiado da CVM reuniu-se para discutir o referido dispositivo e concluiu pela sua inalterabilidade ${ }^{101}$, a despeito das críticas sofridas.

Internacionalmente, foram realizados diversos estudos técnicos e acadêmicos ${ }^{102}$ acerca da regra da rotatividade dos auditores em relação à prestação de serviços de auditoria independente aos seus clientes, sendo que a sua maioria concluiu pela sua não $\operatorname{adoção~}^{103}$.

Competência reguladora. Auditorias independentes. Revista de Direito Mercantil Industrial, Econômico e Financeiro, ano XL, n. 124, p. 208-213. São Paulo, Malheiros, out./dez. 2001.

99 A respeito, cf. Processo CVM RJ 2011/13530, rel. SNC, julgado em 20.12.2011; Processo CVM RJ 2011/14135, rel. DLD, julgado em 06.03.2012; e Processo CVM RJ 2011/11017, rel. DLD, julgado em 10.01.2012.

${ }^{100}$ A respeito, cf. Processo CVM RJ 2011/0288, rel. SGE, julgado em 06.09.2011.

${ }^{101}$ Conforme Ata de Reunião Extraordinária do Colegiado da CVM de 19/09/2003: “[...] Examinadas as opiniões manifestadas, o Colegiado desta CVM considerando, inclusive, o fato de que a regra foi editada há mais de 4 (quatro) anos e o mercado já teve tempo para implementá-la, à falta de uma razão determinante para a sua modificação imediata, entendeu que não deveria haver, no presente momento, alteração na regra do rodízio de firmas, sem que seja precedida de um amplo e refletido debate com os agentes de mercado".

102 (i) GAO - United States General Accounting Office. Report to the Senate Committee on Banking, Housing, and Urban Affairs and the House Committee on Financial Services. Public Accounting Firms: Required Study on the Potential Effects of Mandatory Audit Firm Rotation. Nov. 2003. Disponível em: $<$ http://www.gao.gov/new.items/d04216.pdf >. Acesso em: 5 jan. 2012; (ii) AICPA - American Institute of Certified Public Accountants. Statement of Position Regarding Mandatory Rotation of Audit Firms of Publicly Held Companies. New York: AICPA, 1992. (iii) ARRUÑADA, Benito; PAZ-ARES, Cândido. Mandatory Rotation of Company Auditors: A Critical Examination. International Review of Law and Economics, 1997, v. 17, p. 31-61. Disponível em: <http://www.arrunada.org/files/research/ARRUNADA_PAZ_ARES_1997_Mandatory_Rotation_Aud_IR LE.pdf $>$. Acesso em: 5 jan. 2012; (iv) ICAEW - Institute of Chartered Accountants of England and Wales. Mandatory rotation of audit firms. July 2002. Disponível em: $<$ http://www.icaew.com/ /media/Files/Library/collections/ICAEW\%20archive/mandatory-rotation-ofaudit-firms-review-of-current-requirements-research-and-publications $>$. Acesso em: 5 jan. 2012; (v) CVM MEMO/SNC/GNA/N ${ }^{\circ}$ 073/05.

${ }^{103}$ A respeito, cf. CVM MEMO/SNC/GNA/N 073/05. 
Nos Estados Unidos, aprovou-se em 30 de julho de 2002 o Sarbanes Oxley Act, que previa, entre outras medidas, a rotatividade sobre as funções de auditoria independente como forma de garantir a sua independência. De acordo com a Section $203^{104}$ do referido diploma legal, os auditores independentes passaram a ser obrigados a efetuar uma rotatividade dos seus sócios responsáveis por cada cliente auditado. Optou o legislador norte-americano, contudo, por não impor a rotatividade dos próprios auditores independentes entre si, dispondo a Section 207 do Sarbanes Oxley Act tão somente que seria conduzido, pelo Comptroller General, um estudo a fim de verificar os possíveis impactos da imposição de tal regra ${ }^{105,106}$.

Em relação aos demais países, além do Brasil, somente Itália, Índia, Cingapura e Coreia do $\mathrm{Sul}^{107}$ impuseram o dever de rotatividade dos auditores independentes em relação a seus clientes, não obstante existam diversas referências ao dever de rodízio dos responsáveis técnicos envolvidos quando da prestação de serviços de auditoria por empresas de auditoria por prazo prolongado ${ }^{108}$.

104 "Section 10A of the Securities Exchange Act of 1934 (15 U.S.C. 78j-1), as amended by this Act, is amended by adding at the end the following: "(j) AUDIT PARTNER ROTATION. - It shall be unlawful for a registered public accounting firm to provide audit services to an issuer if the lead (or coordinating) audit partner (having primary responsibility for the audit), or the audit partner responsible for reviewing the audit, has performed audit services for that issuer in each of the 5 previous fiscal years of that issuer."

105 Conforme o texto original: “(a) STUDY AND REVIEW REQUIRED. - The Comptroller General of the United States shall conduct a study and review of the potential effects of requiring the mandatory rotation of registered public accounting firms. (b) REPORT REQUIRED. - Not later than 1 year after the date of enactment of this Act, the Comptroller General shall submit a report to the Committee on Banking, Housing, and Urban Affairs of the Senate and the Committee on Financial Services of the House of Representatives on the results of the study and review required by this section. (c) DEFINITION.-For purposes of this section, the term "mandatory rotation" refers to the imposition of a limit on the period of years in which a particular registered public accounting firm may be the auditor of record for a particular issuer."

106 A respeito, cf. GAO - United States General Accounting Office. Report, op. cit.

107 Cf. (i) GAO - United States General Accounting Office. Report, op. cit., Appendix V; e (ii) MEMO/SNC/GNA/N 073/05.

108 A título de exemplo, o Item 10 da Commission Recomendation of 16 May, 2002 - Statutory Auditors' Independence in the EU: A Set of Fundamental Principles emitida pela Comissão Europeia. Disponível em: $\quad\langle$ http://eur-lex.europa.eu/LexUriServ/LexUriServ.do?uri=OJ:L:2002:191:0022:0057:EN:PDF>. Acesso em: 5 jan. 2012. 
Conforme mencionado, outra forma de perquirir a independência dos auditores é por meio da restrição à prestação dos chamados non-audit services, serviços, contábeis ou não, diversos daqueles de revisão das demonstrações financeiras. Sobre tais serviços, assim dispõe o item 156 da já citada NBC PA 290:

As firmas tradicionalmente prestam a seus clientes de auditoria uma gama de serviços que não são de asseguração que são condizentes com suas habilidades e especialização. A prestação de serviços que não são de asseguração, contudo, pode criar ameaças à independência da firma ou dos membros da equipe de auditoria. As ameaças criadas mais frequentemente são ameaças de autorrevisão, de interesse próprio e de defesa do interesse do cliente.

Ainda a referida NBC PA 290 exemplifica e regula pormenorizadamente diversos non-audit services, interpretando várias hipóteses a fim de auxiliar o auditor independente em relação à prestação ou não desses serviços de forma concomitante à auditoria independente. Entre tais serviços, ressaltamos os de elaboração de registros contábeis e de demonstrações contábeis (itens 167-174), os serviços de avaliação (itens 175-180) e os serviços fiscais, (itens 181-194). Genericamente, tal normativo dispõe, em seu item 158, que

\begin{abstract}
Antes de a firma aceitar um trabalho para prestar serviço que não é de asseguração a um cliente de auditoria, deve-se avaliar se a prestação desse serviço criaria ameaça à independência. [...] Se for criada ameaça que não pode ser reduzida a um nível aceitável mediante a aplicação de salvaguardas, o serviço que não é de asseguração não deve ser prestado. (grifo nosso)
\end{abstract}

Ademais, a referida NBC PA 290, em seu item 160, parece excepcionar a regra de não prestação dos non-audit services pelos auditores independentes para determinadas ${ }^{109}$ entidades relacionadas aos clientes de auditoria, se:

109 São elas “( (a) entidade, que não é cliente de auditoria, que tem controle direto ou indireto sobre o cliente de auditoria; (b) entidade, que não é cliente de auditoria, que tem interesse financeiro direto no cliente, se essa entidade tem influência significativa sobre o cliente, e o interesse no cliente é relevante para essa entidade; e (c) entidade, que não é cliente de auditoria, que está sob o mesmo controle que o cliente de auditoria". 
for razoável concluir que (a) os serviços não criam ameaça de autorrevisão porque os resultados dos serviços não serão submetidos a procedimentos de auditoria, e (b) quaisquer ameaças que são criadas pela prestação desses serviços são eliminadas ou reduzidas a um nível aceitável pela aplicação de salvaguardas.

Já a Instrução Normativa CVM n³08/99, em do seu artigo 23, caput e inciso II, foi mais clara ao vedar aos auditores independentes a prestação de serviços específicos concomitantemente aos serviços de auditoria contábil, conforme a seguir:

Art. 23. É vedado ao Auditor Independente e às pessoas físicas e jurídicas a ele ligadas, conforme definido nas normas de independência do $\mathrm{CFC}$, em relação às entidades cujo serviço de auditoria contábil esteja a seu cargo:

$[\ldots]$

II - prestar serviços de consultoria que possam caracterizar a perda da sua objetividade e independência.

Parágrafo único. São exemplos de serviços de consultoria previstos no caput deste artigo:

I - assessoria à reestruturação organizacional;

II - avaliação de empresas;

III - reavaliação de ativos;

IV - determinação de valores para efeito de constituição de provisões ou reservas técnicas e de provisões para contingências;

V - planejamento tributário;

VI - remodelamento dos sistemas contábil, de informações e de controle interno; ou

VII - qualquer outro produto ou serviço que influencie ou que possa vir a influenciar as decisões tomadas pela administração da instituição auditada.(grifo nosso)

Do rol proposto pela norma acima, ressalte-se que todos os serviços elencados podem ser, e como de fato muitas vezes são, prestados pelos auditores independentes nas operações de incorporação, sobretudo envolvendo companhias abertas, daí a importância de tal dispositivo. Nossa busca por operações de incorporação envolvendo companhias abertas e ocorridas após a publicação da Instrução Normativa CVM nº 308/99 revelou que, em diversos casos, a empresa especializada contratada para a avaliação do acervo da 
sociedade a ser incorporada foi o próprio prestador de serviços de auditoria independente à companhia aberta envolvida ${ }^{110}$.

Apesar da vedação do artigo 23, caput e inciso II da Instrução Normativa CVM n ${ }^{\circ}$ 308/99, não foram encontrados processos administrativos sancionadores no âmbito da CVM com relação à referida concomitância de serviços prestados.

Não obstante, parece haver um conflito entre o disposto no item 160 da NBC PA 290 com o disposto no artigo 23 da Instrução Normativa CVM nº 308/99 ${ }^{111}$.

Nos Estados Unidos, o Sarbanes Oxley Act regula a matéria da prestação dos nonaudit services nas Sections 201 e 202, definindo como regra ${ }^{112}$ a vedação à prestação desses serviços pelos auditores independentes aos seus clientes, e prevendo determinadas

110 A título de exemplo, citamos os seguintes casos: (i) Incorporação pela Telesp Celular da Tele Sudeste Celular Participações S.A., da Tele Leste Celular Participações S.A., e da Celular CRT Participações S.A em 04/12/2005 (auditor Delloitte Touche Tohmatsu Auditores Independentes); (ii) Incorporação pela Companhia Brasileira de Distribuição da Vieri Participações S.A. em 01/12/2006 (auditor Ernst \& Young Auditores Independentes S.S.); (iii) Incorporação pela Obrascon Huarte Lain Brasil S.A. da OHL Brasil Participações em 03/04/2007 (auditor Delloitte Touche Tohmatsu Auditores Independentes); (iv) Incorporação pela Diagnósticos da América S.A. da MD1 Participações Ltda. em 13/10/2011 (auditor KPMG Auditores Independentes); (v) Incorporação pela Companhia Siderúrgica Nacional da CSN Aços Longos em 12/01/2011 (auditor KPMG Auditores Independentes).

111 Ressalte-se que o caput do artigo 23 da Instrução Normativa CVM no 308/99 faz menção às regras emanadas pelo CFC, mas o faz somente para fins de definição do que sejam as pessoas físicas e jurídicas ligadas aos auditores independentes.

112 Except as provided in subsection (h), it shall be unlawful for a registered public accounting firm (and any associated person of that firm, to the extent determined appropriate by the Commission) that performs for any issuer any audit required by this title or the rules of the Commission under this title or, beginning 180 days after the date of commencement of the operations of the Public Company Accounting Oversight Board established under section 101 of the Sarbanes-Oxley Act of 2002 (in this section referred to as the 'Board'), the rules of the Board, to provide to that issuer, contemporaneously with the audit, any nonaudit service, including - "(1) bookkeeping or other services related to the accounting records or financial statements of the audit client; “(2) financial information systems design and implementation; "(3) appraisal or valuation services, fairness opinions, or contribution-in-kind reports; " (4) actuarial services; "(5) internal audit outsourcing services; "(6) management functions or human resources; "(7) broker or dealer, investment adviser, or investment banking services; "(8) legal services and expert services unrelated to the audit; and "(9) any other service that the Board determines, by regulation, is impermissible. (grifo nosso) 
exceções a tal regra, desde que tais exceções estejam de acordo com o interesse público e consistentes com a proteção dos investidores ${ }^{113,114}$.

No direito continental europeu, tanto a Diretiva Europeia 2006/43/EC ${ }^{115}$ como a Recomendação da Comissão Europeia 2002/590/EC ${ }^{116}$ regulam a matéria de forma a

113 "The Board may, on a case by case basis, exempt any person, issuer, public accounting firm, or transaction from the prohibition on the provision of services under section $10 A(g)$ of the Securities Exchange Act of 1934 (as added by this section), to the extent that such exemption is necessary or appropriate in the public interest and is consistent with the protection of investors, and subject to review by the Commission in the same manner as for rules of the Board under section 107".

114 "Because Congress believed that some auditors had been bribed into acquiescence with lucrative Consulting services contracts, the Act prohibited accounting firms from providing certain specific and highly lucrative non-audit services to audit clients that were public corporations, including computer, EDP, and software systems design and implementation. This prophylactic rule has essentially forced most of the major accounting firms to drop their consulting services and focus on auditing". KLEIN, William A.; COFFEE JR., John C.; PARTNOY, Frank. Business organization and finance - legal and economic principles. New York: Foundation Press, 2010, p.219.

${ }^{115}$ Conforme o artigo 22.2 da Diretiva Europeia 2006/43/EC: "Member States shall ensure that a statutory auditor or an audit firm shall not carry out a statutory audit if there is any direct or indirect financial, business, employment or other relationship - including the provision of additional non-audit services between the statutory auditor, audit firm or network and the audited entity from which an objective, reasonable and informed third party would conclude that the statutory auditor's or audit firm's independence is compromised. If the statutory auditor's or audit firm's independence is affected by threats, such as self-review, self-interest, advocacy, familiarity or trust or intimidation, the statutory auditor or audit firm must apply safeguards in order to mitigate those threats. If the significance of the threats compared to the safeguards applied is such that his, her or its independence is compromised, the statutory auditor or audit firm shall not carry out the statutory audit".

116 Conforme o artigo 7.1 da Recomendação da Comissão Europeia 2002/590/EC:

"1. Where a Statutory Auditor, an Audit Firm or one of its Network member firms provides services other than statutory audit work (non-audit services) to an Audit Client or to one of its Affiliates, the overall safeguarding system (A 4.3) of the Statutory Auditor has to ensure that: (a) the individuals employed by either the Audit Firm or its Network member firm neither take any decision nor take part in any decisionmaking on behalf of the Audit Client or one of its Affiliates, or its management while providing a nonaudit service; and $(b)$ where an independence risk remains due to specific threats which may result from the nature of a non-audit service, this risk is reduced to an acceptable level.

2. Even if not involved in the decision-making of the Audit Client or any of its Affiliates, the Statutory Auditor should consider, amongst others, which of the following safeguards in particular may mitigate a remaining independence threat: (a) arrangements to reduce the risk of self-review by compartmentalising responsibilities and knowledge in specific non-audit engagements; (b) routine notification of any audit and non-audit engagement to those in the Audit Firm or Network who are responsible for safeguarding independence, including oversight of ongoing activities; (c) secondary reviews of the Statutory Audit by an Audit Partner who is not involved in the provision of any services to the Audit Client or to one of its Affiliates; or (d) external review by another statutory auditor or advice by the professional regulatory body.

3. Where applicable, and especially with regard to Public Interest Entity clients, the Statutory Auditor should seek to discuss the provision of non-audit services to an Audit Client or to one of its Affiliates with the client's Governance Body (see A. 4.1.2)". 
definir a prestação dos non-audit services como uma ameaça relevante (sobretudo em relação aos serviços de avaliação de empresas e escrituração contábil), mas preveem a possibilidade de prestação de tais serviços em caso de aplicação de salvaguardas suficientes que mitiguem os riscos à objetividade e à independência dos auditores independentes.

Na Itália, vige uma interessante norma com vistas a resguardar a independência dos auditores independentes quanto à prestação dos non-audit services. Nesse país, o Decreto Legislativo 88/1992, em seu artigo $6^{\circ}$, impõe a proibição aos auditores independentes de possuírem em seu objeto social atividade diversa da revisão e da organização contábil ${ }^{117}$. Pelo seu caráter radical, entretanto, tal norma sofreu críticas da doutrina, segundo a qual na prática as grandes empresas de auditoria independente atuantes no país acabaram por constituir sociedades com objetos diversos para a prestação dos non-audit services, mantendo tais sociedades e as próprias sociedades de auditoria independente sob o controle comum de uma controladora estrangeira ${ }^{118}$.

Por fim, conforme mencionado, uma terceira forma de se garantir a independência dos auditores é pela imposição de outras regras de conflito de interesses, especificamente sobre a condição dos auditores independentes e pessoas a eles relacionadas em face do

117 “Art. 6. Iscrizione delle società nel registro.

1. Salvo quanto disposto dall'art. 8, comma 2, hanno diritto all'iscrizione nel registro le società che hanno la sede principale o una sede secondaria con rappresentanza stabile in Italia e rispondono ai seguenti requisiti:

1. oggetto sociale limitato alla revisione e alla organizzazione contabile di aziende; [...]"

118 "La pur rigorosa norma ora citada non teneva conto però del fatto che le società di revisione si collocano, di solito, al centro di una piú vasta "rete", formata da una pluralità di società o studi professionali; sicché la limitazione dell'oggetto sociale si presta ad elusioni che, come l'esperienza ha rivelato, risultano attuate per il tramite delle società o glie studi professionali a latere (o a mone o a valle) della società di revisione, aventi la stessa denominazioni di questa (magri con la specificazione legal o financial ecc.), e fra loro variamente collegati da rapporti di diversa natura: uno si occupa della consulenza legal, un altro della consulenza fiscale, un altro della finanza straordinaria e cosí via. Si è in presenza ciò̀ di una rete o network, all'interno della quale si attua una costante cooperazione, con scambio di esperienze e di personale. Ĺelemento unificante è dato dalla fruizione, da parte di tutte queste società o studi professionali, di servizi ad esse comuni [...], a volta erogati de una sorta di super holding avente sede in altro paese, presso la quale magari viene gestita una cassa centralizzata, che accentrata in sé tutte le entrate e le ridistribuisce fra le varie società o studi". GALGANO, Francesco. GENCHINI, Riccardo. Il nuovo diritto societário, t. 1. Padova: CEDAM, 2006, p. 720-721. 
cliente auditado. Nessa esteira, a já citada NBC PA 290 veda a prestação de serviços de auditoria contábil em situações de conflito de interesses, regulamentando pormenorizadamente as hipóteses de vínculo conjugal ou de parentesco com clientes, relação de trabalho, exercício de cargo ou função incompatível, fixação de honorários condicionais ou de risco, interesses financeiros, participação societária na empresa auditada, eentre outros.

De forma bem mais restrita, o Sarbanes Oxley Act regulamenta a questão no direito norte-americano, ao determinar que

Section 10A of the Securities Exchange Act of 1934 (15 U.S.C. 78j-1), as amended by this Act, is amended by adding at the end the following: "(l) CONFLICTS OF INTEREST.-It shall be unlawful for a registered public accounting firm to perform for an issuer any audit service required by this title, if a chief executive officer, controller, chief financial officer, chief accounting officer, or any person serving in an equivalent position for the issuer, was employed by that registered independent public accounting firm and participated in any capacity in the audit of that issuer during the 1-year period preceding the date of the initiation of the audit".

Finalmente, há de se mencionar que, apesar de o dever de independência ser imposto aos auditores independentes, o seu cumprimento pressupõe a colaboração de terceiros e a imposição de deveres à sociedade que contrata os seus serviços. Dessa forma,

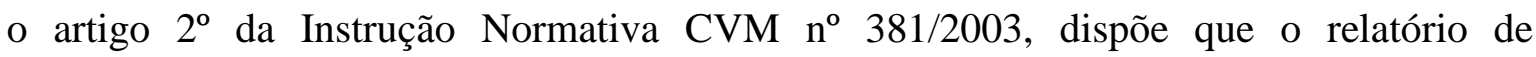
administração das companhias auditadas deve mencionar as seguintes informações relativas à eventual contratação do auditor independente para serviços que não são de auditoria externa: (i) a data da contratação, o prazo de duração, se superior a um ano, e a indicação da natureza de cada serviço prestado; (ii) o valor total dos honorários contratados e o seu percentual em relação aos honorários relativos aos de serviços de auditoria externa; (iii) a política ou os procedimentos adotados pela companhia para evitar a existência de conflito de interesses, perda de independência ou objetividade de seus auditores independentes; e (iv) um resumo da exposição justificativa dos próprios auditores independentes da razão pela qual a sua contratação para tais serviços não afeta a independência e a objetividade necessárias ao desempenho dos serviços de auditoria externa. 


\subsubsection{O sigilo profissional}

Outro pressuposto de atuação imposto aos auditores independentes nas operações de incorporação é o sigilo profissional, absolutamente essencial aos fins a que se destinam os trabalhos do auditor independente, tanto em relação aos serviços de asseguração, como em relação às demais atividades por eles desenvolvidas em tais operações. O sigilo profissional pode ser observado sob dois prismas, sendo que o primeiro diz respeito a um dever de conduta dos auditores independentes, e o segundo a um direito inerente à sua atividade profissional.

O sigilo profissional como um dever possui, em primeiro lugar, um fundamento ético de confidencialidade em relação às informações de propriedade e interesse das companhias auditadas, cuja revelação lhes poderia implicar prejuízos em relação a seus competidores $^{119,120}$.

Em segundo, lugar, a previsão do sigilo profissional como um dever dos auditores independentes possui uma justificativa econômica, relacionada à busca pela eficiência ${ }^{121}$ dos mercados, utilizando-se de instrumentos que garantam a simetria de informações. No caso do sigilo dos auditores independentes, tal busca se faz pela vedação à divulgação das

119 Cf. LISBOA, Lázaro Plácido. Ética geral, op. cit., p. 69-70.

${ }^{120}$ Conforme o item A56 da NBC PA 01 aprovada pela Resolução n ${ }^{\circ}$ 1.201/09 do Conselho Federal de Contabilidade, "os requisitos éticos relevantes estabelecem a obrigação do pessoal da firma observar durante todo o tempo a confidencialidade das informações contidas na documentação do trabalho, a menos que tenha sido fornecida uma autorização específica pelo cliente para a sua divulgação, ou haja um dever legal para isso".

121 "O conceito de mercado eficiente, assim, está diretamente ligado à capacidade de os preços dos títulos refletirem as novas informações sobre as empresas. Quanto mais rápida for a reação da cotação dos títulos, mais eficiente, em princípio, será o mercado; o ideal é que a cotação das ações do mercado secundário reflita apenas as informações disponíveis no momento". CARVALHOSA, Modesto; EIZIRIK, Nelson. A nova lei das S.A. São Paulo: Saraiva, 2002, p. 544. 
diversas informações relevantes possuídas por esses agentes como forma de evitar o insider trading $^{122}$.

Tal viés é naturalmente verificado pela leitura do parágrafo $4^{\circ}$ do artigo 155 da Lei das Sociedades Anônimas" ${ }^{123}$, segundo a qual "é vedada a utilização de informação relevante ainda não divulgada, por qualquer pessoa que a ela tenha tido acesso, com a finalidade de auferir vantagem, para si ou para outrem, no mercado de valores mobiliários". Também no direito comparado encontram-se dispositivos similares em relação à utilização de informações privilegiadas de companhias por terceiros (não diretores), como no direito norte-americano (Regra 10b-5 emitida pela Securities and Exchange Commission), no direito comunitário europeu (artigo $2^{\circ}$ da Diretiva CEE 89/592 e em diversos dispositivos constantes das legislações próprias dos estados-membros da União Europeia $^{124}$ ).

E, finalmente, o fundamento jurídico à imposição do sigilo profissional como um dever dos auditores independentes encontra-se (i) no interesse público inerente à atividade de auditoria independente ${ }^{125}$ e (ii) no próprio direito de personalidade das companhias auditadas, em que estão incluídos os direitos à intimidade e à manutenção do sigilo ${ }^{126}$. Conforme PONTES DE MIRANDA,

122 "O insider trading é, simplificadamente, a utilização de informações relevantes sobre uma companhia, por parte de pessoas que, por força do exercício profissional, estão "por dentro" de seus negócios, para transacionar com susas ações antes que tais informações sejam de conhecimento público. Assim, o insider compra ou vende no mercado a preços que ainda não estão refletindo o impacto de determinandas informações sobre a companhia, que são de seu conhecimento exclusivo". EIZIRIK, Nelson. Insider Trading e Responsabilidade de Administrador de Companhia Aberta. Revista de Direito Mercantil, Industrial, Econômico e Financeiro, ano XXII, n. 50, p. 42-56. São Paulo: RT, abr./jun. 1983.

123 Tal dispositivo legal, conquanto não tenha sido escrito especificamente em relação aos auditores independentes, é absolutamente aplicável a estes, pois se trata de uma previsão genérica a qualquer agente que possua informações privilegiadas, o que é indiscutivelmente o caso dos auditores independentes enquanto participantes de uma operação de incorporação.

${ }^{124}$ Cf. referências legais em PROENÇA, José Marcelo Martins. Insider trading - regime jurídico de informações privilegiadas no mercado de capitais. São Paulo: Quartier Latin, 2005, p. 245 e ss.

125 EIZIRK, Nelson. Auditor independente - sigilo profissional. Revista de Direito Mercantil Industrial, Econômico e Financeiro, ano XXXVI, n. 112, p. 141. São Paulo: Malheiros, 1998.

${ }^{126}$ Ibidem, p. 142. 
Chegamos, assim, a poder explicar, de maneira científica, o direito ao sigilo: é direito de personalidade nato; quando se exerce a liberdade de fazer e de não fazer, ou a de emitir ou não emitir o pensamento, a intimização, ou o segredo, que resulta do ato-fato do exercício de tais liberdades, é objeto de direito à intimidade ou de segredo. $\mathrm{O}$ direito ao segredo é o efeito do ato-fato jurídico, em cujo suporte fático está o atofato do exercício da liberdade de não emitir o pensamento ou os sentimentos. $\mathrm{O}$ direito a velar a intimidade é o efeito do ato-fato jurídico, em cujo suporte fático está o ato-fato do exercício da liberdade de fazer e de não fazer. ${ }^{127}$

Em nosso ordenamento jurídico, verificam-se diversos dispositivos que impõem o sigilo profissional dos auditores independentes como um dever. Em primeiro lugar, a Constituição Federal de 1988, em seu artigo $5^{\circ}, \mathrm{X}$, dispõe que "são invioláveis a intimidade, a vida privada, a honra e a imagem das pessoas, assegurado o direito à indenização pelo dano material ou moral decorrente de sua violação".

Havendo, portanto, um direito constitucional erga omnes à privacidade, garantido às pessoas, físicas ou jurídicas, somente poderia existir no contrapolo da relação jurídica entre a companhia e o auditor independente o dever deste ao sigilo profissional em relação às informações que lhe são reveladas.

Ademais, além do já citado parágrafo $4^{\circ}$ do artigo 155 da Lei das Sociedades Anônimas, no âmbito penal, encontramos o artigo $154^{128}$ do Código Penal e o artigo 27$\mathrm{D}^{129}$ da Lei 6.385/76. Já o Código de Ética Profissional do Contador, aprovado pela

127 PONTES DE MIRANDA, Francisco Cavalcanti. Tratado de direito privado, t. 7. 1. ed. at. por Vilson Rodrigues Alves. Rio de Janeiro: Bookseller, 2000, p. 165.

128 “Art. 154 - Revelar alguém, sem justa causa, segredo, de que tem ciência em razão de função, ministério, ofício ou profissão, e cuja revelação possa produzir dano a outrem:

Pena - detenção, de três meses a um ano, ou multa."

129 “Art. 27-D. Utilizar informação relevante ainda não divulgada ao mercado, de que tenha conhecimento $e$ da qual deva manter sigilo, capaz de propiciar, para si ou para outrem, vantagem indevida, mediante negociação, em nome próprio ou de terceiro, com valores mobiliários: (Artigo incluído pela Lei $n^{o}$ 10.303, de 31.10.2001)

Pena - reclusão, de 1 (um) a 5 (cinco) anos, e multa de até 3 (três) vezes o montante da vantagem ilícita obtida em decorrência do crime." 
Resolução 803/96 do CFC, prevê em seu artigo $2^{\circ}$, II que o profissional de contabilidade deve "guardar sigilo sobre o que souber em razão do exercício profissional lícito [...]". Prevê ainda artigo $3^{\circ}$ do mesmo ato normativo que é vedado ao profissional de contabilidade

XV - revelar negociação confidenciada pelo cliente ou empregador para acordo ou transação que, comprovadamente, tenha tido conhecimento; XVI - emitir referência que identifique o cliente ou empregador, com quebra de sigilo profissional, em publicação em que haja menção a trabalho que tenha realizado ou orientado, salvo quando autorizado por eles.

O inciso VII do artigo $4^{\text {o }}$ da Instrução CVM no 308/99 dispõe que as empresas de auditoria independente devem

manter escritório profissional legalizado em nome da sociedade, com instalações compatíveis com o exercício da atividade de auditoria independente, em condições que garantam a guarda, a segurança e o sigilo dos documentos e informações decorrentes dessa atividade, bem como a privacidade no relacionamento com seus clientes. ${ }^{130}$ (grifo nosso)

No plano da autorregulação, o citado Statements on Management Accounting ${ }^{131}$, padrão internacional aceito e recomendado no Brasil, dispõe que os profissionais contabilistas devem atuar de acordo com as seguintes premissas:

i. Refrain from discussing confidential level of professional competence by ongoing development of their knowledge and skills;

ii. Inform subordinates as appropriate regarding the confidentiality of information acquired in the course of their work and monitor their activities to assure the maintenance of that confidentiality.

iii. Refrain from using or appearing to use confidential information acquired in the course of their work for unethical or illegal advantage either personally or through third parties.

${ }^{130} \mathrm{O}$ inciso III do artigo $3^{\circ}$ do mesmo ato normativo prevê exigência análoga em relação aos auditores pessoa física.

131 INSTITUTE OF MANAGEMENT ACCOUNTANTS. Statements on management accounting: objectives of management accounting - Statement 1B. New York, 1982. 
Por outro lado, os mesmos fundamentos jurídicos que suportam a imposição do sigilo profissional como um dever, o garantem como um direito do auditor independente enquanto prestador de serviços às companhias envolvidas na operação de incorporação. Nesse sentido, diversos dispositivos legais assim dispõem.

Em primeiro lugar, a Constituição Federal de 1988, em seu artigo 5, XII e XIV determina que

$$
\begin{aligned}
& \text { XII - é inviolável o sigilo da correspondência e das comunicações } \\
& \text { telegráficas, de dados e das comunicações telefônicas, salvo, no } \\
& \text { último caso, por ordem judicial, nas hipóteses e na forma que a lei } \\
& \text { estabelecer para fins de investigação criminal ou instrução } \\
& \text { processual penal; } \\
& \text { XIV - é assegurado a todos o acesso à informação e resguardado o sigilo da } \\
& \text { fonte, quando necessário ao exercício profissional; }
\end{aligned}
$$

Também sobre o sigilo profissional como um direito dos auditores independentes, dispõe o artigo 229, II do atual Código Civil Brasileiro que "ninguém pode ser obrigado a depor sobre fato a cujo respeito, por estado ou profissão, deva guardar segredo", e o artigo 363, IV do Código de Processo Civil que "a parte e o terceiro se escusam de exibir, em juízo, o documento ou a coisa se a exibição acarretar a divulgação de fatos, a cujo respeito, por estado ou profissão, devam guardar segredo".

Em vista dos dispositivos acima mencionados, discute-se a adequação do direito à confidencialidade dos auditores independentes em face das regras de fiscalização das suas atividades pelas autoridades competentes.

Em relação à atividade do Poder Judiciário, entende-se não ser possível a exigência arbitrária de informações e papéis de trabalho dos auditores independentes sob o 
argumento da busca pela verdade material ${ }^{132}$. Conforme voto do Ministro Cesar Asfor Rocha no Recurso em Mandado de Segurança $n^{\circ}$ 9.612/SP,

o segredo profissional é exigência fundamental da vida social que deve ser respeitado como princípio de ordem pública, por isso mesmo que o Poder Judiciário não dispõe de força cogente para impor a sua revelação, salvo hipótese de existir lei específica disciplinando a possibilidade de quebra. $^{133}$

Sobre a fiscalização das atividades dos auditores independentes pela CVM, o texto original do artigo $9^{\circ}$, I e "e" da Lei 6.385/76 estabeleceu limites ao dispor que esta autarquia poderia "examinar registros contábeis, livros ou documentos". Já o Decreto 3.995/01 alterou o texto do referido dispositivo legal, dispondo que a CVM poderia

examinar e extrair cópias de registros contábeis, livros ou documentos, inclusive programas eletrônicos e arquivos magnéticos, ópticos ou de qualquer outra natureza, bem como papéis de trabalho de auditores independentes, devendo tais documentos ser mantidos em perfeita ordem e estado de conservação pelo prazo mínimo de cinco anos.

Sustenta-se, entretanto, inconstitucionalidade do referido Decreto 3.995/01 e, como consequência, da alteração no artigo $9^{\circ}$ da Lei 6.385/76, uma vez que um decreto presidencial não poderia revogar lei formal. Em discussão judicial sobre o assunto, o Tribunal Regional Federal - $2^{\mathrm{a}}$ Região (TRF2) ${ }^{134}$ deferiu Agravo de Instrumento interposto pela CVM o fim de cassar a liminar concedida pelo Juízo da $16^{\text {a }}$ Vara Federal do Rio de Janeiro (Mandado de Segurança $n^{\circ}$ 200551010196180) que determinou a suspensão dos efeitos de termos de intimação expedidos pela CVM à Pricewaterhouse Coopers Auditores Independentes para a entrega de cópias dos documentos de auditoria.

${ }^{132}$ Há, entretanto, hipóteses específicas em que o referido entendimento pode ser relativizado. Conforme voto do Ministro Sidnei Beneti, "não há que se falar em indevida exposição de segredo profissional perante terceiros, pois a disputa judicial se dá entre sócios e ex-sócios, revelando-se a controvérsia como conflito interna corporis". STJ RMS 28.456/SP, rel. Min. Sidnei Beneti, julgado em 16.08.2011.

133 STJ RMS 9.612/SP, rel. Min. Cesar Asfor Rocha, julgado em 3.09.1998.

${ }^{134}$ Processo no 2005.02.01.011808-6/RJ, Oitava Turma do TRF-2 ${ }^{\mathrm{a}}$ Região, rel. Des. Guilherme Calmon Nogueira da Gama, julgado em 08.11.2005. 
No referido pleito, a Oitava Turma do Tribunal do TRF2 entendeu que o Decreto 3.995/01 não apresenta inconstitucionalidade, discorrendo que,

os inspetores da Comissão de Valores Mobiliários tiveram acesso aos documentos e papéis de trabalho da Agravante, o que evidencia que o sigilo de tais documentos não é absoluto. [...] Na decisão ora recorrida não foi mencionado que o Decreto $\mathrm{n}^{\circ} 3.995 / 01$ teria revogado o disposto na Lei $n^{\circ} 6.385 / 76$, e sim que não haveria razão para que os inspetores da CVM não tivessem possibilidade de ter cópias dos documentos em se considerando que tiveram acesso ao conteúdo deles. Tal ato normativo o Decreto $n^{\circ} 3.995 / 2001$ - apenas explicitou a possibilidade da exigência de cópia, inexistindo violação à Constituição Federal de $1988 .{ }^{135}$

Ademais, o artigo 25 da Instrução Normativa CVM no 308/99 dispõe que a o auditor independente deverá:

III - conservar em boa guarda pelo prazo mínimo de cinco anos, ou por prazo superior por determinação expressa desta Comissão em caso de Inquérito Administrativo, toda a documentação, correspondência, papéis de trabalho, relatórios e pareceres relacionados com o exercício de suas funções;

$[\ldots]$

V - dar acesso à fiscalização da CVM e fornecer ou permitir a reprodução dos documentos referidos no item III, que tenham servido de base à emissão do relatório de revisão especial de demonstrações trimestrais ou do parecer de auditoria;

Já o citado artigo $2^{\circ}$, II do Código de Ética Profissional do Contador, aprovado pela Resolução 803/96 do CFC, prevê que o profissional de contabilidade deve

guardar sigilo sobre o que souber em razão do exercício profissional lícito, [...], ressalvados os casos previstos em lei ou quando solicitado por autoridades competentes, entre estas os Conselhos Regionais de Contabilidade (grifo nosso).

${ }^{135}$ Conforme voto do Des. Federal Guilherme Calmon Nogueira da Gama. 
Sob tais fundamentos legais, a CVM exige dos auditores independentes amplo acesso e cópias das informações e documento recebidos durante o processo de auditoria ${ }^{136}$.

\subsubsection{A competência profissional}

Devido ao interesse público e à grande importância das atividades desenvolvidas pelos auditores independentes, há constante preocupação das entidades reguladoras e autoreguladoras quanto à qualificação profissional de tais agentes. Nesse sentido, impõe-se aos auditores independentes diversas regras relativas à sua competência profissional.

No plano da auto-regulação internacional, o item 130.1 do Código de Ética Profissional da IFAC dispõe sobre o dever de manutenção de conhecimento e proficiência a um nível adequado que garanta aos clientes receberem serviços profissionais ${ }^{137}$. Já o Statements on Management Accounting dispõe que o dever de competência profissional significa "manter um nível adequado de competência profissional pelo desenvolvimento contínuo de seus conhecimentos e habilidades"138.

No direito comunitário europeu, a Diretiva 2011/35/EU prevê, em seus artigos $6^{\circ}$ a 13, diversos requisitos técnico-profissionais, bem como deveres de aprimoramento qualificação técnica, teórica e prática, dos auditores independentes.

No Brasil, a própria Constituição Federal, em seu artigo 5, XIII dispõe que "é livre o exercício de qualquer trabalho, ofício ou profissão, atendidas as qualificações

136 A respeito, cf. Processo Administrativo Sancionador CVM RJ 2005/8134, rel. PTE, julgado em 03.04.2007; e Processo Administrativo Sancionador CVM RJ 2006/420, rel. DPS, julgado em 03.10.2006.

137 INTERNATIONAL FEDERATION OF ACCOUNTANTS. Code of Ethics for Professional Accountants, June 2005, rev. July 2006, p. 1103 a 1115 . Disponível em: <http://www.ifac.org/sites/default/files/publications/files/ifac-code-of-ethics-for.pdf $>$. Acesso em: 22 jan. 2013.

138 INSTITUTE OF MANAGEMENT ACCOUNTANTS. Statements on management accounting: objectives of management accounting - Statement 1B. New York, 1982. 
profissionais que a lei estabelecer"(grifo nosso). A referida norma constitucional, portanto, permite a restrição do exercício profissional à comprovação de qualificação, uma vez que há determinadas profissões que dependem de capacidade especial, de certa formação técnica, científica ou cultural ${ }^{139}$.

No âmbito da regulação da CVM, a Deliberação n CVM 549/08 prevê o Programa de educação Continuada dos Auditores Independentes, e a Instrução Normativa CVM n ${ }^{\circ}$ 308/99 dispõe sobre diversas regras preventivas e repressivas relativamente à qualificação profissional dos auditores independentes, conforme dispostos em seus artigos $3^{\circ}$, II e $\mathrm{V}, 4^{\circ}$ VI e VIII, 15, 30, 32, 33 e 34.

Por fim, existem também diversas normas do CFC a respeito da qualificação técnica dos profissionais de contabilidade, sobretudo dos auditores independentes. A título de exemplo, citamos o artigo $2^{\circ}$, III e X do Código de Ética Profissional do Contador, aprovado pela Resolução 803/96 do CFC, bem como a normas técnicas do CFC NBC PA 01, NBC P 4, NBC P 5, e NBC TA 220.

\subsubsection{A lealdade}

Outro dever geral de atuação imposto aos auditores independentes é o dever de lealdade (integrity), com o qual se busca evitar atuações em hipóteses em que sejam violados os objetivos éticos da empresa auditada ou em que o próprio profissional contenha limitações ou restrições profissionais.

De acordo com o Statements on Management Accounting ${ }^{140}$, o dever de lealdade relaciona-se às seguintes premissas de atuação:

\footnotetext{
139 A respeito, cf. SILVA, José Afonso da. Comentário contextual à Constituição. 2. ed. São Paulo: Malheiros, 2006, p. 108.

140 INSTITUTE OF MANAGEMENT ACCOUNTANTS. Statements on management accounting: objectives of management accounting - Statement 1B. New York, 1982.
} 
i. Avoid actual or apparent conflicts of interest and advise all appropriate parties of any potential conflict;

ii. Refrain from engaging in any activity that would prejudice their ability to carry out their duties ethically;

iii. Refuse any gift, favor, or hospitality that would influence or would appear to influence their actions;

$i v$. Refrain from either actively or passively subverting the attainment of the organization's legitimate and ethical objectives;

$v$. Recognize and communicate professional limitations or other constraints that would preclude responsible judgment or successful performance of any activity;

vi. Communicate unfavorable as well as favorable information and professional judgments or opinions;

vii. Refrain from engaging in or supporting any activity that would discredit the profession.

Com a imposição de um dever de lealdade, exige-se dos auditores independentes uma conduta direta e honesta nas relações com as companhias auditadas e com o mercado $^{141}$, o que pressupõe atuações de acordo com o critério de boa-fé objetiva ${ }^{142}$.

Trata-se, portanto, de uma imposição geral que se relaciona à própria condição do auditor independente enquanto prestador de serviço de contabilidade, de acordo com os padrões éticos e profissionais que se esperam desses profissionais. Especificamente para os auditores independentes, a imposição de tal dever é essencial, pois este presta serviços de asseguração ao mercado, garantindo fidedignidade às informações prestadas pelas companhias.

${ }^{141}$ Conforme o Código de Ética Profissional da International Federation of Accountants (IFAC): “110.1 The principle of integrity imposes an obligation on all professional accountants to be straightforward and honest in professional and business relationships. Integrity also implies fair dealing and truthfulness. 110.2 A professional accountant should not be associated with reports, returns, communications or other information where they believe that the information: (a) Contains a materially false or misleading statement; (b) Contains statements or information furnished recklessly; or (c) Omits or obscures information required to be included where such omission or obscurity would be misleading". INTERNATIONAL FEDERATION OF ACCOUNTANTS. Code of Ethics for Professional Accountants, June 2005, rev. July 2006, p. 1103 a 1115 . Disponível em: <http://www.ifac.org/sites/default/files/publications/files/ifac-code-of-ethics-for.pdf $>$. Acesso em: 22 jan. 2013.

${ }^{142}$ Para Forgioni, boa-fé objetiva significa "adotar o comportamento jurídico e normalmente esperado dos "comerciantes cordatos", dos agentes economicos ativos e probos em determinado mercado (ou "em certo ambiente institucional”), sempre de acordo com o direito". FORGIONI, Paula Andrea. Teoria geral dos contratos empresariais. São Paulo: Revista dos Tribunais, 2009, p.99. 
Por tal motivo, deve-se resguardar não somente a competência, o sigilo e a objetividade do seu trabalho, como será abordado nos subcapítulos subsequentes, mas também evitar quaisquer atos que comprometam, mesmo que aparentemente, a sua lealdade enquanto prestadores de serviço. Assim, o Código de Ética Profissional do Contador, aprovado pela Resolução 803/96 do CFC, prevê em seu artigo $2^{\circ}$, I que o profissional de contabilidade deve "exercer a profissão com zelo, diligência, honestidade e capacidade técnica, observada toda a legislação vigente, em especial aos Princípios de Contabilidade e as Normas Brasileiras de Contabilidade, e resguardados os interesses de seus clientes elou empregadores, sem prejuízo da dignidade e independência profissionais".

Já o artigo 15 da Instrução Normativa CVM n $308 / 99$ prevê a suspensão ou o cancelamento do registro do auditor independente nas seguintes hipóteses:

I - seja comprovada a falsidade dos documentos ou declarações apresentados para a obtenção do registro na Comissão de Valores Mobiliários;

II - sejam descumpridas quaisquer das condições necessárias à sua concessão ou à sua manutenção ou se for verificada a superveniência de situação impeditiva;

III - tenham sofrido pena de suspensão ou cancelamento do registro profissional, transitada em julgado, aplicada pelo órgão fiscalizador da profissão; ou

IV - forem, por sentença judicial transitada em julgado:

a) declarados insolventes;

b) condenados em processo-crime de natureza infamante, ou por crime ou contravenção de conteúdo econômico;

c) impedidos para exercer cargo público; ou

d) declarados incapazes de exercerem os seus direitos civis. (grifo nosso)

\subsection{Dos papéis dos auditores independentes nas operações de incorporação}

4.2.1. A análise das demonstrações financeiras e a emissão do parecer de auditoria 


\subsubsection{As demonstrações financeiras e a operação de incorporação}

De acordo com o artigo 176 da Lei das Sociedades Anônimas, as demonstrações financeiras incluem os seguintes documentos: (i) o balanço patrimonial, (ii) as demonstração dos lucros ou prejuízos acumulados, (iii) a demonstração do resultado do exercício, (iv) a demonstração dos fluxos de caixa, e (v) a demonstração do valor adicionado, esta no caso de companhia aberta.

E a elaboração das demonstrações financeiras envolve esforços conjuntos dos administradores da companhia, dos profissionais contabilistas responsáveis pela escrituração contábil e dos auditores independentes ${ }^{143}$, e requer cuidadosa adequação às regras contábeis brasileiras.

As primeiras regras a serem observadas serão aquelas contidas nos artigos 176 a 205 da Lei das Sociedades Anônimas, bem como nos artigos 247 a 250 e 275 da mesma lei em relação aos grupos de sociedades de fato e de direito, respectivamente. Adicionalmente, existem diversos atos normativos emanados pelo CFC, pela CVM e pelos demais órgãos reguladores e autorreguladores.

Sobre tais normas contábeis, há uma preocupação recorrente de que estejam em consonância com os mais elevados padrões internacionais de contabilidade, razão pela qual a padronização dos métodos de elaboração de demonstrações contábeis e dos critérios de revisão mostra-se essencial nos dias atuais.

${ }^{143}$ Em regra, os auditores independentes não deveriam participar diretamente da elaboração das demonstrações financeiras da companhia. Entretanto, os auditores independentes são constantemente consultados pela administração das companhias auditadas sobre a utilização de determinados critérios e princípios contábeis durante o processo de elaboração das demonstrações financeiras, uma vez que é de grande interesse das companhias auditadas e da sua administração que os auditores independentes emitam pareceres sem ressalvas sobre tais demonstrações financeiras. Nesse sentido, verifica-se influência direta dos auditores no processo de elaboração das demonstrações financeiras, fato contestado por parte da doutrina norte-americana, uma vez que esses são contratados e descontratados pela própria companhia. Conforme EISENBERG, "virtually the accountant's only mechanism for enforcing this limit is his power to withhold a clean certificate from the corporation's financial statements. Yet by law, and largely by practice, the selection, tenure and dismissal of an accountant is entirely in the hands of the management. Moreover, management is not hesitant to use this power". EISENBERG, Melvin Aron. The structure of the corporation. Washinton: Beard Books, 2006, p. 196. 
Nesse sentido, verificam-se esforços do direito brasileiro em convergir para as normas internacionais de contabilidade (International Financial Reporting Standards IFRS) emanadas pelo International Accouting Standards Board (IASB). Como resultado de tais esforços, ressaltem-se as relevantes alterações na Lei das Sociedades Anônimas trazidas pelas Leis 11.638/07 e 11.941/09 e a aprovação de normas técnicas pelo Comitê de Pronunciamentos Contábeis (CPC) da CVM, entre as quais o Pronunciamento Técnico CPC 15, que trata da combinação de negócios entre companhias. Da mesma forma, ressaltem-se os esforços do IBRACON e do CFC ao traduzir e adaptar as normas internacionais de contabilidade do IFAC, tendo como consequência a emissão de diversas normas técnicas aprovadas em resoluções do próprio CFC.

Ademais, conforme disposto no subcapítulo 3.2 acima, o objeto precípuo dos trabalhos dos auditores independentes e, como consequência, uma das principais atividades por eles desenvolvidas em operações de incorporação, é a revisão das demonstrações financeiras da companhia auditada.

Entretanto, a despeito de o referido escopo se referir às demonstrações financeiras como um gênero $^{144}$, o balanço patrimonial ocupará uma posição de destaque na revisão das demonstrações financeiras elaboradas com o fim específico de servir como base para uma operação de incorporação. Isso porque o balanço patrimonial da companhia incorporada servirá como base para a avaliação do patrimônio líquido a ser vertido para a sociedade incorporadora e, como consequência, para a definição do valor do aumento do seu capital social e da relação de substituição das ações de propriedade dos acionistas da sociedade incorporada.

Nesse ponto, entendemos importante ressaltar a ausência, no ordenamento jurídico brasileiro, de normas que imponham o dever de elaboração de um balanço patrimonial especial para servir como base nas operações de incorporação. No direito pátrio, a única

\footnotetext{
${ }^{144}$ Conforme sugerem os artigos 12 e 13 da Instrução Normativa CVM nº 319/1999 e o parágrafo $3^{\circ}$ do artigo 177 da Lei das Sociedades Anônimas.
} 
imposição de elaboração de um balanço patrimonial especial encontra-se no caput e parágrafo $1^{\circ}$ do art. 21 da Lei $9.249 / 95^{145}$, mas trata-se de imposição de norma tributária para fins de apuração dos impactos fiscais da operação, que não vincula a operação de incorporação do ponto de vista societário.

A elaboração de balanço especial para fins de incorporação é necessária à atualização das bases para a operação, as quais serão utilizadas pelos auditores independentes em sua avaliação e aprovadas pelos acionistas nas assembleias gerais. Dessa forma, a ausência de normas específicas sobre a elaboração de um balanço patrimonial especial de incorporação implica um risco de utilização de bases obsoletas pelos auditores independentes e pelos acionistas em operações dessa natureza. Conforme crítica de GARRIGUES e URÍA:

Las normas de valoración que pueden aconsejarse o imponerse para el balance ordinario anual no sirven para un balance de apertura, o para un balance de liquidación, o para un balance hecho en vista de la fusión de sociedades. ${ }^{146,147}$

Assim, no direito brasileiro os balanços patrimoniais utilizados nas operações poderão ser aqueles elaborados para fins de apuração dos resultados do último exercício social e, mesmo que por um ato de liberalidade dos sócios seja elaborado um balanço patrimonial especial para esse fim, deverá vincular-se às regras definidas nos artigos $178 \mathrm{a}$ 184-A da Lei das Sociedades Anônimas, sendo os auditores independentes também responsáveis pelo conteúdo do balanço patrimonial.

Outra importante questão a ser ressaltada a respeito das demonstrações financeiras é a premissa de o balanço patrimonial não representar uma verdade, mas somente uma das

\footnotetext{
145 "Art. 21. A pessoa jurídica que tiver parte ou todo o seu patrimônio absorvido em virtude de incorporação, fusão ou cisão deverá levantar balanço específico para esse fim, no qual os bens e direitos serão avaliados pelo valor contábil ou de mercado.

$\S 1^{\circ}$ O balanço a que se refere este artigo deverá ser levantado até trinta dias antes do evento."

146 GARRIGUES, Joaquin; URÍA, Rodrigo. Comentarios, op. cit., p. 365.

147 Cf. ainda críticas de Bulgarelli em BULGARELLI, Waldirio. Fusões, op. cit., p. 167-174.
} 
possíveis formas de contabilizar as contas da companhia, numa tentativa de mostrar com a maior clareza possível a situação patrimonial da companhia num exato momento.

Nesse sentido, COMPARATO afirma que,

O balanço, como de resto toda a contabilidade, não pode jamais ser um simples reflexo de fatos econômicos, porque se trata de uma interpretação simbólica e, portanto, convencional da realidade. Os fatos econômicos não passam para os livros contábeis no estado bruto, mas são traduzidos, simbolicamente, em conceitos e valores; ou seja, são previamente estimados e valorados, segundo um critério determinado e em função de uma finalidade específica. [...] Mas entre a realidade econômica e a sua tradução contábil interfere, necessariamente, um juízo de valor, uma estimativa axiológica cuja imprecisão e contestabilidade jamais poderão ser suprimidas, porque inerentes ao próprio processo de conhecimento. A verdade contábil é, pois, simplesmente relativa. ${ }^{148,149}$ (grifo nosso)

Esse é também o motivo pelo qual o artigo 176 da Lei das Sociedades Anônimas não exige que as demonstrações financeiras reflitam a real ou verdadeira situação patrimonial da companhia, mas tão somente a exprima com clareza.

De forma semelhante, no direito espanhol, dispõe o artigo 254.(2) do Real Decreto Legislativo 1/2010 que "estos documentos, que forman una unidad, deberán ser redactados con claridad y mostrar la imagen fiel del patrimonio, de la situación financiera y de los resultados de la sociedad, de conformidad con esta ley y con lo previsto en el Código de Comercio".

Já no direito italiano, o artigo 2423 do Codice Civile, apesar de definir a necessidade de clareza e precisão dos balanços, determina também devem representar a

${ }^{148}$ COMPARATO, Fabio Konder. Ensaios, op. cit., p. 31-32.

${ }^{149}$ No mesmo sentido, conforme GUARRIGUES e URÍA, "la veracidad, como adecuación a la verdad, representa sólo una aspiración ideal que ninguna ley podría formular coactivamente, por lo mismo que la valoración en el balance no es nunca resultado de un cálculo de aritmética, sino un juicio estimativo, el cual aun siendo consecuencia de una apreciación de buena fe está siempre sometido al influjo de todo los riesgos y probabilidades inherentes a la especulación mercantil y a la inseguridad de todo criterio subjetivo". GARRIGUES, Joaquin; URÍA, Rodrigo. Comentarios a la ley de sociedades anónimas, t. 1. Madrid: Instituto de Estudios Politicos, 1952, p. 327. 
realidade econômica de forma verdadeira, ao dispor que "il bilancio deve essere redatto con chiarezza e deve rappresentare in modo veritiero e corretto la situazione patrimoniale e finanziaria della società e il risultato economico dell'esercizio".

Entretanto, a doutrina italiana sustenta que o conceito de veracidade não é aplicável às demonstrações financeiras senão de forma relativa e interpretativa, admitindo que existem diferentes métodos de avaliação de ativos e passivos. Dessa forma destaca que tal conceito de veracidade está ligado à elaboração de balanços que atendam a dois princípios $^{150}$ : (i) o da avaliação a um valor permanente, que significa não avaliar de acordo com critérios baseados em situações contingentes (cuidando-se ainda para não haver superavaliação), e (ii) o da continuidade ou identidade do balanço patrimonial, que significa a adoção dos mesmos critérios de avaliação nos sucessivos exercícios sociais.

Referindo-se ao direito francês, RIPERT entende que a verdade do balanço é relativa, razão pela qual se deve punir a fraude e a falta de sinceridade dos balanços, mas não a sua inexatidão. Conforme o autor,

C'est la fraude qui est punissable. Voilà pourquoi il faut parler de la sincerité du bilan et non de son exactitude. La loi ne pouvait punir l'établissement d'un bilan inexact, car il n'y a aucun bilan qui soit rigoureusement exact, et on a pu parler avec raison de la relativité du bilan, car le bilan est établi sur la compatibilité et ne traduit pas les valeurs réelles. ${ }^{151}$

E, porque existem diversas formas de efetuar lançamentos contábeis e expressar a situação patrimonial de uma companhia, existe uma margem para que erros e fraudes ocorram, por consequência prejudicando a avaliação das companhias incorporadas, ou mesmo das incorporadoras, nos casos em que será necessária a avaliação do seu patrimônio líquido.

${ }^{150}$ FERRI, Giuseppe. Le società, op. cit., p. 554-556.

${ }^{151}$ RIPERT, Georges. Traité élémentaire de droit commercial. Paris: LGDJ, 1974, p. 859. 
Para evitar tais infortúnios, é essencial que existam regras contábeis satisfatórias e uma adequada fiscalização do seu cumprimento, papel que será desenvolvido não somente pelos órgãos reguladores, como pelos agentes asseguradores, como os auditores independentes.

\subsubsection{A revisão das demonstrações financeiras}

Conforme abordagem anterior, a revisão das demonstrações contábeis constitui atividade precípua dos auditores independentes e é essencial para dar credibilidade às demonstrações financeiras que suportarão uma operação de incorporação.

No Brasil, há uma regulação esparsa da atividade de auditoria independente, sendo que os dispositivos que regulam a referida atividade são analisados em detalhes ao longo do presente estudo. Em resumo tais atividades são reguladas pelas seguintes leis e atos normativos:

a) Lei 6.404/76: artigo 133, III (parecer de auditoria como documento da administração); artigo $134, \S \S 1^{\circ}$ e $2^{\circ}$ (presença dos auditores independentes nas assembleias gerais ordinárias); artigo 142, IX e $\$ 2^{\circ}$ (competência do conselho de administração para a contratação e destituição dos auditores independentes); artigo $163, \S^{\circ}$ e $5^{\circ}$ (solicitação de informações pelo conselho fiscal aos auditores independentes); artigo 177, $3^{\circ}$ (auditoria das demonstrações financeiras de companhias abertas); e artigo 275, $\$ 4^{\circ}$ (auditoria das demonstrações financeiras consolidadas de grupos de direito);

b) Lei 6.385/76: artigo $1^{\circ}$ (escopo legal); artigo $2^{\circ}, \S 3^{\circ}$, II (auditoria de demonstrações financeiras de agentes emissores de valores mobiliários); artigo 9, I e "e" (fiscalização, pela CVM, dos trabalhos de auditoria independente); artigo 10-A (convênio para o estudo de princípios e padrões de contabilidade e auditoria); artigo 22, $1^{\circ}$, IV (competência normativa da CVM sobre atividades de auditoria); artigo 26 (registro e responsabilidade dos auditores independentes); 
c) Lei 11.638/07: artigo $3^{\circ}$ (aplicabilidade das regras de auditoria independente às sociedades de grande porte);

d) atos normativos expedidos pela CVM, como a Instrução Normativa no 308/99 (regulação do exercício da atividade de auditoria independente), a Instrução Normativa $n^{\circ} 381 / 03$ (divulgação dos non-audit services), o artigo 12 da Instrução Normativa nº $319 / 99$ (obrigatoriedade de auditoria independente sobre as demonstrações financeiras que servirem como base às operações de incorporação, fusão e cisão) e diversos Ofícios-Circulares e Deliberações;

e) atos normativos específicos expedidos pelos órgãos reguladores, como, por exemplo, a Resolução $\mathrm{n}^{\circ}$ 3.198/04 do Conselho Monetário Nacional, a Resolução $n^{\circ}$ 118/04 do Conselho de Seguros Privados, e a Resolução normativa no 396/10 da Agência Nacional de Energia Elétrica;

f) diversas normas técnicas expedidas pelo CFC, as quais definem pormenorizadamente as principais regras de atuação doas auditores independentes; $\mathrm{e}$

g) normas expedidas pelas entidades autorreguladoras, como o IBRACON, o IASB e o IFAC.

Diante do referido contexto normativo, importa delimitar o objetivo da revisão das demonstrações financeiras, como forma de definir os deveres específicos dos auditores independentes em operações de incorporação, bem como o alcance da sua responsabilidade perante a companhia e os terceiros prejudicados; esse último tema será tratado no Capítulo 5 adiante.

De acordo com o item 11 da NBC TA 200, aprovada pela Resolução CFC 1.203/09, os objetivos da revisão das demonstrações financeiras procedida pelos auditores independentes são os seguintes:

a) obter segurança razoável de que as demonstrações contábeis como um todo estão livres de distorção relevante, devido a fraude ou erro, possibilitando assim que o auditor opine sobre se as demonstrações contábeis foram elaboradas, em todos os aspectos relevantes, em conformidade com a estrutura de relatório financeiro aplicável; e 
b) apresentar parecer sobre as demonstrações contábeis e comunicar-se como exigido pelas NBC TAs, em conformidade com as constatações do auditor.

Da análise da norma citada, portanto, conclui-se que o escopo da auditoria contábil não é o de apontar toda e qualquer distorção entre a realidade fática e a escrituração contábil, mas tão somente o de garantir uma segurança razoável às demonstrações financeiras elaboradas pela companhia, apontando eventuais distorções relevantes, resultantes de erro ou fraude, entendendo-se como relevantes as disparidades que possam influenciar de forma relevante na decisão econômica tomada com base nas demonstrações financeiras $^{152}$.

E, justamente porque o objetivo da revisão das demonstrações financeiras é a garantia de uma asseguração razoável pela verificação de distorções relevantes, há doutrina que classifica a obrigação do auditor independente como de resultado ${ }^{153}$, e não de meio, posição com a qual nos filiamos.

Ressalte-se, ademais, que a asseguração razoável das demonstrações financeiras somente será obtida ${ }^{154}$ quando o auditor independente possuir suficientes e adequadas evidências de auditoria ${ }^{155,156}$ que possibilitem reduzir a um nível aceitavelmente baixo o risco de auditoria ${ }^{157}$.

152 Conforme o item 6 da NBC TA 200, “em geral, as distorções, inclusive as omissões, são consideradas relevantes se for razoável esperar que, individual ou conjuntamente, elas influenciem as decisões econômicas dos usuários tomadas com base nas demonstrações contábeis".

153 PEREIRA, Alexandre Demetrius. Auditoria das demonstrações contábeis: uma abordagem jurídica e contábil. São Paulo: Atlas, 2011, p. 84 e ss.

154 Conforme item 5 da NBC TA 200.

155 Conforme o item 13.b da NBC TA 200, "evidências de auditoria-informações usadas pelo auditor para chegar às conclusões em que baseia a sua opinião. As evidências de auditoria incluem informações contidas nos registros contábeis subjacentes às demonstrações contábeis e outras informações. Para fins das NBC TAs: (i) A suficiência das evidências de auditoria é a medida da quantidade da evidência de auditoria. A quantidade necessária da evidência de auditoria é afetada pela avaliação do auditor dos riscos de distorção relevante e também pela qualidade de tal evidência. (ii) A adequação da evidência de auditoria é a medida da qualidade da evidência de auditoria; isto é, sua relevância e confiabilidade no fornecimento de suporte às conclusões em que se baseia a opinião do auditor". 
Finalmente, há de se ressaltar que os auditores independentes não podem obter certeza, nem garantir que as demonstrações financeiras estejam totalmente livres de distorções relevantes e, por consequência, não são obrigados a reduzir o risco de auditoria a zero. Isso ocorre porque sempre existirão limitações impostas aos trabalhos desenvolvidos pelos auditores que inviabilizarão a plena compreensão da realidade fática e escritural, denominadas limitações inerentes em uma auditoria.

Tais limitações podem ocorrer tanto por premência de informações recebidas, pela natureza dessas informações ou mesmo pela natural limitação cognitiva que é inerente aos auditores independentes ${ }^{158}$, resultando, portanto, das seguintes variáveis:

a) da natureza das informações financeiras;

b) da natureza dos procedimentos de auditoria; e

c) da necessidade de que a auditoria seja conduzida dentro de um período de tempo razoável e a um custo razoável.

156 As evidências de auditoria são pormenorizadamente reguladas pelo Conselho Federal de Contabilidade nas normas NBT TA 500, NBT TA 501, NBT TA 505 e NBT TA 520.

157 Conforme o item 13.c da NBC TA 200, "risco de auditoria é o risco de que o auditor expresse uma opinião de auditoria inadequada quando as demonstrações contábeis contiverem distorção relevante. $O$ risco de auditoria é uma função dos riscos de distorção relevante e do risco de detecção". O risco de distorção relevante é pormenorizadamente regulado pelo Conselho Federal de Contabilidade na norma NBC TA 315.

158 Tal limitação cognitiva, entendemos, é devida à racionalidade limitada inerente aos agentes econômicos, ao contrário do que se pressupunha na economia neoclássica. Conforme SIMON, "[...] the outlines of theory begin to emerge when we substitute for "economic man" or "administrative man" a choosing organism of limited knowledgeand ability. This organism's simplifications of the real world for purposes of choice introduces discrepancies between the simplified model and the reality; and these discrepancies, in turn, serve to explain many of the phenomena of organization behavior". SIMON, Herbert A. A behavioral model of rational choice. The Quarterly Journal of Economics, v. 69, n. 1, fev. 1955, p. 113. A respeito, cf. também FORGIONI, Paula Andrea. Teoria geral, op. cit., p. 66-69. 


\subsubsection{O parecer dos auditores independentes}

O parecer dos auditores independentes é o instrumento pelo qual estes expõem as suas conclusões em relação às evidências de auditoria obtidas, constituindo, portanto, o vínculo entre a responsabilidade desses agentes e o conteúdo das demonstrações financeiras apresentadas, sobretudo do balanço patrimonial.

De acordo com o item 13 da norma NBC TA 700, aprovada pela Resolução CFC $n^{\circ}$ 1.231/2009, a opinião do auditor independente indicará se (i) as demonstrações contábeis divulgam adequadamente as práticas contábeis selecionadas e aplicadas; (ii) as práticas contábeis selecionadas e aplicadas são consistentes com a estrutura de relatório financeiro aplicável e são apropriadas; (iii) as estimativas contábeis feitas pela administração são razoáveis; (iv) as informações apresentadas nas demonstrações contábeis são relevantes, confiáveis, comparáveis e compreensíveis; (v) as demonstrações contábeis fornecem divulgações adequadas para permitir que os usuários previstos entendam o efeito de transações e eventos relevantes sobre as informações incluídas nas demonstrações contábeis; e se (vi) a terminologia utilizada nas demonstrações contábeis, incluindo o título de cada demonstração contábil, é apropriada.

Sob tal premissa, os auditores independentes deverão emitir a sua opinião de forma a evidenciar clara e objetivamente se as demonstrações financeiras foram elaboradas de forma satisfatória. Caso estejam de acordo com o conteúdo das demonstrações financeiras, será emitido um parecer sem ressalvas ${ }^{159,160}$, em que constará a afirmação de que as demonstrações contábeis apresentam adequadamente, em todos os aspectos relevantes, a posição patrimonial e financeira da companhia, o desempenho de suas operações e os seus fluxos de caixa consolidados.

159 Ou uma "opinião não modificada", conforme texto do item 16 da norma NBC TA 700 emitida pelo CFC, que é uma tradução oficial da norma respectiva emitida pela IFAC.

${ }^{160}$ A respeito, cf. ainda (i) LONGO, Claudio Gonçalo. (FIPECAFI) Manual de auditoria, op. cit., p. 326; (ii) LINS, Eduardo dos Santos. Auditoria: uma abordagem prática com ênfase na auditoria externa. São Paulo: Atlas, 2011, p. 217-218; e (iii) PEREIRA, Alexandre Demetrius. Auditoria das demonstrações contábeis, op. cit., p. 155. 
Entretanto, o item 17 da referida NBC TA 700 e o item 6 da norma NBC TA 705, aprovada pela Resolução CFC n ${ }^{\circ} 1.232 / 2009$, determinam que, o auditor independente não poderá emitir um parecer sem ressalvas quando (i) ele conclui, com base na evidência de auditoria obtida, que as demonstrações contábeis, como um todo, apresentam distorções relevantes, ou (ii) quando o auditor não consegue obter evidência de auditoria apropriada e suficiente para concluir que as demonstrações contábeis como um todo não apresentam distorções relevantes.

Diante de tais hipóteses, os auditores deverão emitir um parecer com $\operatorname{ressalvas}^{161,162}$, um parecer adverso ${ }^{163,164}$, ou mesmo abster-se de emitir um parecer.

O parecer com ressalvas deverá ser emitido quando (i) tendo obtido evidência de auditoria apropriada e suficiente, o auditor conclui que as distorções, individualmente ou em conjunto, são relevantes, mas não generalizadas nas demonstrações contábeis ou quando (ii) o auditor independente não consegue obter evidência apropriada e suficiente de auditoria para embasar sua opinião, mas ele conclui que os possíveis efeitos de distorções não detectadas, se houver, sobre as demonstrações contábeis poderiam ser relevantes, mas não generalizados.

Já o parecer adverso deverá ser emitido quando o auditor independente, tendo obtido evidência de auditoria apropriada e suficiente, conclui que as distorções,

161 Ou uma “opinião com ressalva”, conforme texto do item 7 da norma NBC TA 700.

162 A respeito, cf. ainda (i) LONGO, Claudio Gonçalo. (FIPECAFI) Manual de auditoria, op. cit., p. 339 e ss.; (ii) LINS, Eduardo dos Santos. Auditoria: uma abordagem prática com ênfase na auditoria externa. São Paulo: Atlas, 2011, p. 218-219; e (iii) PEREIRA, Alexandre Demetrius. Auditoria das demonstrações contábeis, op. cit., p. 155.

163 Ou uma “opinião adversa”, conforme texto do item 8 da norma NBC TA 700.

${ }^{164}$ A respeito, cf. ainda (i) LONGO, Claudio Gonçalo. (FIPECAFI) Manual de auditoria, op. cit., p. 339 e ss.; (ii) LINS, Eduardo dos Santos. Auditoria, op. cit., p. 221-222; e (iii) PEREIRA, Alexandre Demetrius. Auditoria das demonstrações contábeis, op. cit., p. 155. 
individualmente ou em conjunto, são relevantes e generalizadas para as demonstrações contábeis.

Por fim, o auditor independente deverá abster-se de emitir uma opinião quando (i) não consegue obter evidência de auditoria apropriada e suficiente para embasar sua opinião e ele conclui que os possíveis efeitos de distorções não detectadas, se houver, sobre as demonstrações contábeis poderiam ser relevantes e generalizados ${ }^{165}$, ou quando (ii) em circunstâncias extremamente raras envolvendo diversas incertezas, conclui que, independentemente de ter obtido evidência de auditoria apropriada e suficiente sobre cada uma das incertezas, não é possível expressar uma opinião sobre as demonstrações contábeis devido à possível interação das incertezas e seu possível efeito cumulativo sobre essas demonstrações contábeis ${ }^{166,167}$.

Ressalte-se ainda que a NBC TA 700 determina que o parecer do auditor independente deve necessariamente conter uma seção referente à responsabilidade dos administradores sobre as demonstrações contábeis, e outra seção referente à responsabilidade do auditor. Na primeira seção constará uma explicação de que a administração é responsável pela elaboração das demonstrações contábeis de acordo com a estrutura de relatório financeiro aplicável e pelos controles internos determinados pela administração como sendo necessários para permitir a elaboração de demonstrações contábeis que não apresentem distorção relevante, seja ela cauda por fraude ou erro ${ }^{168}$.

Na seção sobre a responsabilidade dos auditores independentes deverá haver menção ao fato de a auditoria ter sido elaborada de acordo com as normas brasileiras e internacionais de auditoria, bem como de que o auditor ter cumprido com as exigências

\footnotetext{
165 Conforme o item 9 da norma NBC TA 700.

166 Conforme o item 10 da norma NBC TA 700.

167 A respeito, cf. ainda (i) LONGO, Claudio Gonçalo. (FIPECAFI) Manual de auditoria, op. cit., p. 339 e ss.; (ii) LINS, Eduardo dos Santos. Auditoria, op. cit., p. 222-225; e (iii) PEREIRA, Alexandre Demetrius. Auditoria das demonstrações contábeis, op. cit., p. 155-156.

168 Conforme o item 26 da norma NBC TA 700.
} 
éticas a ele impostas, planejando e realizando a auditoria para obter segurança razoável quanto às demonstrações ${ }^{169}$. O profissional deverá, ademais, descrever a auditoria, especificando ${ }^{170}$ que:

a) a auditoria envolve a execução de procedimentos para obtenção de evidência de auditoria a respeito dos valores e divulgações nas demonstrações contábeis;

b) os procedimentos selecionados dependem do julgamento do auditor, incluindo a avaliação dos riscos de distorção relevante nas demonstrações contábeis, seja ela causada por fraude ou erro. Nessas avaliações de risco, o auditor considera os controles internos relevantes à elaboração das demonstrações contábeis da entidade para planejar procedimentos de auditoria que sejam apropriados nas circunstâncias, mas não para fins de expressar uma opinião sobre a eficácia dos controles internos da entidade;

c) a auditoria inclui, também, a avaliação da adequação das práticas contábeis utilizadas e a razoabilidade das estimativas contábeis feitas pela administração, bem como a avaliação da apresentação das demonstrações contábeis, tomadas em conjunto.

Não obstante as regras acima, em diversos casos os pareceres de auditoria são emitidos com erros técnicos que podem implicar compreensão equivocada do mercado quanto às demonstrações financeiras das companhias auditadas. Em vista de tal situação, a Superintendência de Normas Contábeis e de Auditoria da CVM emitiu o OfícioCircular/CVM/SNC 12/2009, com o qual procurou destacar e corrigir os seguintes principais erros técnicos dos auditores independentes quando da elaboração de pareceres sobre as demonstrações financeiras das companhias abertas auditadas:

a) parágrafos de Ressalvas sem a quantificação dos efeitos decorrentes ${ }^{171}$;

169 Conforme o item 30 da norma NBC TA 700.

${ }^{170}$ Conforme o item 31 da norma NBC TA 700.

${ }^{171}$ Conforme texto do Ofício-Circular/CVM/SNC 12/2009, "foram identificados casos em que os auditores independentes incluíram parágrafos de ressalvas em seus respectivos pareceres, contudo, sem mencionar 
b) omissões de informações relevantes em notas explicativas e ausência de ressalva no parecer dos auditores independentes ${ }^{172}$;

c) ressalva incluída no Parecer por limitação na extensão do exame de determinado item relevante, não devidamente esclarecida ${ }^{173}$;

d) utilização de Parágrafo de Ênfase em vez de Parágrafo de Ressalva ${ }^{174}$;

e) emissão de Parecer com Ressalva para casos em que se aplicariam Parecer com Abstenção de Opinião ${ }^{175}$;

f) emissão de Parecer com Ressalva apesar da existência de múltiplas ressalvas que conduziriam à emissão de Parecer Adverso ${ }^{176}$.

\subsubsection{A avaliação da companhia incorporada}

de forma expressa a quantificação dos feitos nas contas ou subgrupos das contas do Ativo, Passivo, Patrimônio Líquido e Resultado, de acordo om o determinado pelo inciso IV do artigo 25 da Instrução CVM No 308/99".

172 Conforme texto do Ofício-Circular/CVM/SNC 12/2009, "Foram identificados casos em que a companhia aberta auditada omitiu informações relevantes em notas explicativas, comprometendo, assim, a qualidade do conteúdo informacional das demonstrações contábeis apresentadas e prejudicando a análise e interpretação das referidas demonstrações por parte dos usuários".

173 Conforme texto do Ofício-Circular/CVM/SNC 12/2009, "Foram identificados casos em que os auditores independentes incluíram parágrafo de ressalva em seu parecer em decorrência de não haver examinado e aplicado procedimentos de auditoria sobre determinado item das demonstrações contábeis da companhia auditada, contudo, limitando-se a informar que "não nos foi possível examinar...", omitindose, assim, as razões que impossibilitaram o referido exame”.

${ }^{174}$ Conforme texto do Ofício-Circular/CVM/SNC 12/2009, "Foram identificados casos em que auditores independentes optaram por atribuir tratamento de parágrafo de ênfase em seu parecer para determinadas situações que, em verdade, deveriam ser motivo de parágrafo de ressalva".

175 Conforme texto do Ofício-Circular/CVM/SNC 12/2009, "Foram identificados casos em que os auditores independentes emitiram opinião sobre as demonstrações contábeis das companhias auditadas, não obstante a existência de limitações significativas na extensão dos trabalhos de auditoria, que resultaram na inclusão de ressalvas no parecer. Ocorreram casos em que tais limitações são relevantes em seu conjunto ou mesmo a existência de uma limitação de escopo específica, contudo, o item não examinado é de tal relevância que não permitiria que o auditor emitisse opinião sobre as demonstrações contábeis objeto da auditoria".

176 Conforme texto do Ofício-Circular/CVM/SNC 12/2009, "Foram identificados casos em que os auditores independentes incluíram várias ressalvas no parecer sobre determinadas demonstrações contábeis que, em seu conjunto, dada a relevância dos desvios apontados, poder-se-ia dizer que as demonstrações contábeis auditadas não representavam a posição patrimonial e financeira daquela companhia para 31/12/2008". 


\subsubsection{Conceitos gerais}

Entre os trabalhos mais importantes realizados pelos auditores independentes nas operações de incorporação está a avaliação do patrimônio líquido da sociedade a ser incorporada, que será vertido para a sociedade incorporadora. Apesar de tal trabalho não estar incluído nas atividades de auditoria independente, trata-se de trabalho essencialmente desenvolvido pelos auditores independentes, sobretudo nas grandes operações envolvendo companhias abertas. Por tal motivo, o IBRACON publicou, em 24 de setembro de 2007, a norma NPA 14, que dispõe sobre os "laudos de avaliação emitidos por auditor independente, ${ }^{, 177}$.

A importância dos trabalhos desenvolvidos pelos auditores independentes enquanto peritos é central, pois o valor definido pelos avaliadores em relação à sociedade a ser incorporada servirá como referência tanto para o cálculo do aumento ou da redução do capital social da sociedade incorporadora, como para a relação de substituição das ações da sociedade incorporada pelas ações da incorporadora.

A regulação da avaliação dos ativos e passivos a serem vertidos para a companhia é, portanto, uma preocupação antiga do direito comercial, pois, além das importantes consequências do resultado final da avaliação, é nesse momento que historicamente se verifica a ocorrência de diversas fraudes por parte dos acionistas mancomunados com os peritos avaliadores. Conforme CARVALHO DE MENDONÇA,

177 O IBRACON, apesar de ser uma pessoa jurídica de direito privado, portanto sem poderes regulatórios, emite diversas normas no âmbito da autorregulação são oficialmente incorporadas à regulação das atividades dos auditores independentes pela sua reconhecida qualidade técnica. Nesse sentido, o artigo 20 da Instrução Normativa CVM no 308/99, dispõe que "o Auditor Independente - Pessoa Física e o Auditor Independente - Pessoa Jurídica, todos os seus sócios e integrantes do quadro técnico deverão observar, ainda, as normas emanadas do Conselho Federal de Contabilidade - CFC e os pronunciamentos técnicos do Instituto Brasileiro de Contadores - IBRACON, no que se refere à conduta profissional, ao exercício da atividade e à emissão de pareceres e relatórios de auditoria"(grifo nosso). 
As maiores extorsões contra as sociedades anônimas têm sido praticadas de conveniência com esses louvados ${ }^{178}$, instrumentos dos interessados. Assembleias incompetentes e compostas de pessoal recrutado pelos fundadores aprovam as avaliações mais escandalosas e imorais! ${ }^{179}$

Citando, ainda, VALVERDE,

A contribuição em bens, para a formação de capital das sociedades anônimas, foi sempre a fonte inesgotável de fraude na organização de empresas duvidosas, lançadas, entretanto, ao público, com hábeis prospectos e reclames sedutores. A majoração do valor dos bens, mediante o concurso de "testas de ferro", prepara o caminho das especulações ardilosas, imaginadas pelos fundadores. ${ }^{180}$

Ambas as citações acima são comentários ao artigo $5^{\circ}$ do revogado Decreto-Lei 2.627/40, que já previa regras específicas para a avaliação dos ativos a serem vertidos para a sociedade objeto do aumento de capital $^{181}$. Conforme abordado anteriormente, atualmente a avaliação da companhia a ser incorporada segue o rito do artigo $8^{\text {o182 }}$ da Lei

178 “Louvados" é a expressão utilizada pelo autor ao se referir aos avaliadores.

${ }^{179}$ CARVALHO DE MENDONÇA, José Xavier. Tratado, op. cit., v. 3, p. 355-356.

180 VALVERDE, Trajano de Miranda. Sociedades por Ações: comentários ao decreto-lei 2.627, de 26 de setembro de 1940, v. 1. Rio de Janeiro: Forense, 1959, p. 109.

181 “Art. $5^{\circ}$ A avaliação dos bens será feita por três peritos, nomeados em assembléia geral dos subscritores, convocada pela imprensa e presidida por um dos fundadores. A assembléia instalar-se-á com a presença de subscritores que representem metade, pelo menos, do capital social.

$\S 1^{\circ}$ Os peritos deverão apresentar laudo fundamentado e instruido com os documentos relativos aos bens avaliados, e estarão presentes à assembléia, que dele deverá conhecer, afim de prestarem as informações que lhes forem solicitadas.

$\S 2^{\circ}$ Se o subscritor aceitar o valor aprovado pela assembléia, os bens incorporar-se-ão ao patrimônio da companhia, competindo aos primeiros diretores cumprir as formalidades necessárias para a respectiva transmissão. Si a assembléia não aprovar a avaliação, ou o subscritor não aceitar o valor aprovado, ficará sem efeito o projeto de constituição da companhia.

$\S 3^{\circ}$ Os bens não poderão ser incorporados ao patrimônio da sociedade por valor acima do que lhes tiver dado o subscritor.

$\S 4^{\circ}$ Aplica-se à assembléia acima referida o disposto no art. 82.

$\S 5^{\circ}$ Os peritos respondem perante a sociedade pelos prejuizos que lhe causarem por culpa ou dolo, sem prejuizo da responsabilidade criminal em que tenham incorrido."

182 “Art. $8^{\circ}$ A avaliação dos bens será feita por 3 (três) peritos ou por empresa especializada, nomeados em assembleia-geral dos subscritores, convocada pela imprensa e presidida por um dos fundadores, instalando-se em primeira convocação com a presença de subscritores que representem metade, pelo menos, do capital social, e em segunda convocação com qualquer número.

$\S 1^{\circ}$ Os peritos ou a empresa avaliadora deverão apresentar laudo fundamentado, com a indicação dos critérios de avaliação e dos elementos de comparação adotados e instruído com os documentos relativos 
das Sociedades Anônimas, que prevê, com importantes inovações, regras similares ao regime anterior.

Adotando como objeto do presente Capítulo a análise das regras de avaliação enquanto escopo dos trabalhos dos auditores independentes ${ }^{183}$, são destacados determinados pontos essenciais do referido artigo $8^{\circ}$ da Lei das Sociedades Anônimas, conforme análise a seguir.

Em primeiro lugar, o caput do artigo $8^{\circ}$ dispõe que a avaliação deve ser feita por três peritos individuais ou empresa especializada, sendo esta última possibilidade uma inovação ${ }^{184}$ da atual Lei das Sociedades Anônimas face ao regime anterior. Sobre tais avaliadores, a lei não estabelece critérios ou competências para a sua caracterização como especialistas ${ }^{185}$, razão pela qual aqueles que possuem como atividade principal a prestação

aos bens avaliados, e estarão presentes à assembleia que conhecer do laudo, a fim de prestarem as informações que lhes forem solicitadas.

$\S 2^{\circ} \mathrm{Se}$ o subscritor aceitar o valor aprovado pela assembleia, os bens incorporar-se-ão ao patrimônio da companhia, competindo aos primeiros diretores cumprir as formalidades necessárias à respectiva transmissão.

$\S 3^{\circ}$ Se a assembleia não aprovar a avaliação, ou o subscritor não aceitar a avaliação aprovada, ficará sem efeito o projeto de constituição da companhia.

$\S 4^{\circ}$ Os bens não poderão ser incorporados ao patrimônio da companhia por valor acima do que lhes tiver dado o subscritor.

$\S 5^{\circ}$ Aplica-se à assembleia referida neste artigo o disposto nos $\$ \S 1^{\circ}$ e $2^{\circ}$ do artigo 115 .

$\S 6^{\circ}$ Os avaliadores e o subscritor responderão perante a companhia, os acionistas e terceiros, pelos danos que lhes causarem por culpa ou dolo na avaliação dos bens, sem prejuízo da responsabilidade penal em que tenham incorrido; no caso de bens em condomínio, a responsabilidade dos subscritores é solidária."

${ }^{183}$ Não atentando, portanto, aos os procedimentos gerais envolvidos na assembleia da sociedade incorporadora para a aprovação do laudo, o que já foi objeto do Capítulo 2 acima.

${ }^{184}$ Conforme a Exposição de Motivos no 196, de 24 de junho de 1976, do Ministério da Fazenda, “admite-se que a avaliação seja feita por empresas especializadas, e não apenas por três peritos, porque em muitos casos somente uma organização empresarial dispõe dos recursos e experiência necessários à avaliação de conjuntos industriais, estabelecimentos ou patrimônios".

185 Encontramos, na doutrina e na jurisprudência, tentativas de delimitação do conceito de especialista. Conforme manifestação da CVM no Parecer CVM/SJU no 49/1985, "a especialização mínima, para um perito, deverá ser entendida como o curso ou cursos que o órgão de classe (se a profissão é regulamentada) exige como requisito mínimo para a sua profissão. A experiência, é claro, também conta, no caso do perito, porquanto é de se esperar que o expert com dez anos de experiência terá mais tarimba do que outro colega, com cinco anos apenas. Em termos estritamente jurídicos, temos o Código de Processo Civil, que prevê a figura do perito, a quem não devem faltar a capacidade civil e a capacidade técnica, devidamente reconhecida. No entanto tal capacidade técnica geralmente atinge as raias do 
de serviços de auditoria independente (i.e., a revisão de demonstrações financeiras) também prestam serviços de avaliação, sobretudo considerando que são também profissionais contabilistas devidamente credenciados.

Em segundo lugar, o parágrafo $1^{\circ}$ do artigo $8^{\circ}$ da Lei das Sociedades Anônimas prevê que a forma de apresentação da avaliação dos ativos a serem vertidos à companhia cujo capital social será aumentado (i.e., da companhia a ser incorporada) será necessariamente um laudo de avaliação, que deverá conter, no mínimo, a indicação dos critérios de avaliação e dos elementos de comparação adotados. Trata-se, pois, de importante inovação em relação ao regime anterior, pois o parágrafo $1^{\circ}$ do artigo $5^{\circ}$ do Decreto-Lei 2.627/40 não previa requisitos mínimos dos laudos de avaliação, fato que auxiliava eventuais erros e/ou fraudes na avaliação.

Em terceiro lugar, o parágrafo $4^{\circ}$ do artigo $8^{\circ}$ da atual Lei das Sociedades Anônimas repete a regra do regime anterior ${ }^{186}$, ao determinar que os bens não poderão ser incorporados ao patrimônio da companhia por valor acima do que lhes tiver dado o subscritor. Trata-se da única limitação imposta por lei ao conteúdo da avaliação, tendo como fundamento evitar a ocorrência de superavaliações, conforme será abordado adiante.

Em quarto lugar, o artigo $8^{\circ}$ da atual Lei das Sociedades Anônimas prevê duas importantes regras relativas ao papel dos auditores independentes enquanto avaliadores da sociedade a ser incorporada, que são (i) a obrigatoriedade de presença na assembleia geral de aprovação do laudo para prestação de informações e esclarecimentos, e (ii) a

subjetivismo, assistindo entretanto ao que se julgar prejudicado, o direito de impugnar o laudo pericial, a arbitragem, a avaliação, etc.". Na doutrina, conforme PHILOMENO COSTA, "empresa especializada em avaliação de bens - para efeitos do disposto no art. $8^{\circ}$ - é aquela que se dedica economicamente à estima de bens em geral ou é aquela que coincide de ter o mesmo objeto da companhia constituenda". COSTA, Philomeno J. Anotações às companhias, v. 1. São Paulo: RT, 1980, p. 163. A lei das sociedades anônimas alemã de 1965 (Aktiengesetz), mais específica, prevê em seu §33(4) que os peritos avaliadores (sejam pessoas físicas ou empresas de auditoria) devem necessariamente ser profissionais experientes e especializados em contabilidade. Conforme o §33(4) da Aktiengezets, "Als Gründungsprüfer sollen, wenn die Prüfung keine anderen Kenntnisse fordert, nur bestellt warden 1. Personen, die in der Buchführung ausreichend vorgebildet und erfahren sind; 2. Prüfungsgesellschaften, von deren gesetzlichen Vertretern mindestens einer in der Buchführung ausreichend vorgebildet und erfahren ist".

${ }^{186}$ Conforme parágrafo $3^{\circ}$ do artigo $5^{\circ}$ do Decreto-Lei 2.627/40. 
responsabilidade civil pelos prejuízos que causarem em relação à avaliação. Tais regras serão analisadas, respectivamente, no subcapítulo 4.2.3 e no capítulo 5 adiante.

Além do mencionado parágrafo $1^{\circ}$ do artigo $8^{\circ}$ da Lei das Sociedades Anônimas, há outros dispositivos legais aplicáveis à avaliação de uma companhia quando da sua incorporação por outra companhia. A fim de garantir a observância ao princípio da realidade do capital social, o artigo 226 da Lei das Sociedades Anônimas prevê como condição para a efetivação da incorporação que a avaliação, feita por peritos ou empresa especializada, do patrimônio líquido da companhia a ser incorporada deverá ser, no mínimo, igual ao montante do capital social a realizar. Repita-se, tal imposição se trata tão somente de uma condição para a efetivação da operação de incorporação, e não uma imposição à avaliação pelos auditores independentes.

Ademais, a Lei 11.941/09, resultado de conversão em lei da Medida Provisória n449/08, serviu para alterar o parágrafo $3^{\circ}$ do artigo 226 da Lei das Sociedades Anônimas, com o fim de delegar à CVM competência para estabelecer normas sobre a avaliação e contabilização de operações de incorporação que envolvam companhia aberta.

$\mathrm{Na}$ esteira do referido parágrafo $3^{\circ}$ do artigo 226 da Lei das Sociedades Anônimas, a CVM editou a Deliberação CVM n ${ }^{\circ}$ 580, a qual aprovou o Pronunciamento Técnico CPC 15, que trata da combinação de negócios, conceito que inclui a operação de incorporação ${ }^{187}$. Tal normativo, entretanto, refere-se mais à contabilização da combinação de negócios e à avaliação dos ativos e passivos envolvidos do que à avaliação da companhia incorporada em si pelos diferentes critérios possíveis, conforme será abordado adiante.

187 Curiosamente, a Deliberação CVM no 580 não fez referência em seu texto ao parágrafo $3^{\circ}$ do artigo 226 da Lei das Sociedades Anônimas, mas somente aos parágrafos $3^{\circ}$ e $5^{\circ}$ do artigo 177 da mesma lei. Não obstante, entende-se que a competência da CVM para editar o referido normativo está também definida no parágrafo $3^{\circ}$ do artigo 226 da Lei das Sociedades Anônimas, na medida em que o conceito de combinação de negócios do próprio Pronunciamento Técnico CPC 15 inclui as operações de incorporação. Conforme texto do referido normativo, "combinação de negócios é uma operação ou outro evento por meio do qual um adquirente obtém o controle de um ou mais negócios, independentemente da forma jurídica da operação. Neste Pronunciamento, o termo abrange também as fusões que se dão entre partes independentes (inclusive as conhecidas por true mergers ou merger of equals)". 
Portanto, a matéria de avaliação das companhias abertas envolvidas numa operação de incorporação ${ }^{188}$ ainda carece de regulação pormenorizada por parte da CVM e de autorregulação por parte de outras entidades interessadas ${ }^{189}$. Com base na competência delegada pelo parágrafo $3^{\circ}$ do artigo 226 da Lei das Sociedades Anônimas, espera-se que a CVM regule a matéria de forma similar à regulação realizada por meio do Anexo III à Instrução normativa CVM no 361/2002 à matéria da avaliação para fins de oferta pública de aquisição de ações de companhia aberta (OPA), cuja aplicação analógica entendemos possível à presente hipótese de incorporação entre companhias abertas.

\subsubsection{Interesses tutelados e objetivo da avaliação}

As regras gerais de avaliação anteriormente mencionadas têm como fim a tutela de interesses diversos ${ }^{190}$. Pretende-se, pois, tutelar os interesses dos próprios acionistas subscritores (no caso de uma incorporação, dos acionistas da sociedade que será incorporada), que pretendem maximizar o valor de sua futura participação na sociedade incorporadora. Pretende-se tutelar os interesses dos atuais acionistas da sociedade incorporadora, que desejam a menor diluição em sua atual participação societária, e o interesse dos futuros acionistas, os investidores. Pretende-se tutelar os interesses dos credores, que têm no capital social uma garantia, e, finalmente, pretende-se tutelar o interesse público, representado pelo interesse na continuidade da empresa que terá o capital aumentado.

188 Assim como nas operações de fusão e cisão.

${ }^{189}$ Historicamente, diversas entidades internacionais foram criadas especificamente com o fim de fomentar a autorregulação da atividade de avaliação de empresas, como a American Society of Appraisers (ASA), a Canadian Institute of Chartered Business Valuators (CICBV), a International Association of Consultants, Valuators and Analysts (IACVA), a Fédération Française des Experts em Evaluation (FFEE), e o Organismo Italiano di Valutazione (OIV). No Brasil, foi criado recentemente pela Associação Nacional de Executivos de Finanças, Administração e Contabilidadade (ANEFAC) o Comitê Brasileiro de Avaliação de Negócios (CBAN), com o mesmo objetivo.

${ }^{190}$ CARVALHOSA, Modesto. Comentários, op. cit.,v. 1, p. 116. 
$\mathrm{Na}$ avaliação da companhia incorporada, verifica-se a existência de duas formas de desvios do seu valor: a superavaliação e a subavaliação. A primeira, pelo potencial prejuízo aos interesses sociais e de terceiros, possui efeitos externa corporis. Já a segunda produz efeitos interna corporis, pois preocupa apenas os próprios acionistas e a companhia. Conforme ASCARELLI,

As diversas consequiências da superavaliação e da subavaliação decorrem do fato de que, ao passo que uma superavaliação contrasta com a tutela do interesse dos terceiros e da integridade do capital social, uma subavaliação respeita apenas ao interesse do acionista, não prejudicando, ao contrário, a integridade do capital social. ${ }^{191,192}$

A preocupação dos credores da sociedade em relação à superavaliação reside no fato de que esta contrariará o princípio da realidade do capital social, essencial para a manutenção da sua função de garantia dos credores, exercida pelo capital social ${ }^{193,194}$. Ademais, preocupam-se os credores com o fato de que, a despeito do direito de oposição que possuem em relação à operação de incorporação por força do artigo 232 da Lei das Sociedades Anônimas, poderem não ter tempo hábil ou meios suficientes para averiguar o procedimento de avaliação, hipótese em que poderão ser prejudicados.

Ainda, além de representar uma distorção no próprio capital social da companhia incorporadora, o que em si já é contrário ao interesse social, a superavaliação do

191 ASCARELLI, Tullio. Problemas, op. cit., p. 428.

${ }^{192}$ No excerto, o autor comenta a superavaliação e a subavaliação em relação aos ativos do balanço patrimonial, mas entendemos que o mesmo raciocínio é aplicável à avaliação dos patrimônios líquidos a ser vertido para a sociedade incorporadora.

193 Como forma de observar o princípio da realidade do capital social, a Lei das Sociedades Anônimas prevê, em seu artigo 226, que as operações de incorporação "somente poderão ser efetivadas nas condições aprovadas se os peritos nomeados determinarem que o valor do patrimônio ou patrimônios líquidos a serem vertidos para a formação de capital social é, ao menos, igual ao montante do capital a realizar". Há também diversos outros dispositivos da Lei das Sociedades Anônimas com o fim de manter a observância ao princípio da realidade do capital social, como o artigo 170, o artigo 107, o artigo 80, I e II, dentre outros.

194 Como mecanismo de defesa às operações incorporações com avaliações superestimadas, é comum os bancos comerciais exigirem em seus contratos de mútuo a inserção de cláusula de vencimento antecipado em caso de reorganizações societárias ou transferências de controle ocorridas em relação ao mutuário. 
patrimônio da companhia incorporada poderá também prejudicar os sócios da sociedade incorporadora, cuja participação será erroneamente diluída após a incorporação. Por tais motivos, a superavaliação poderá implicar responsabilidade dos auditores independentes perante terceiros, acionistas e a própria companhia, conforme será abordado no Capítulo 5 adiante.

Já a subavaliação prejudicará exclusivamente o acionista da companhia que será incorporada (subscritor), que poderá aprovar a avaliação abaixo do valor por ele dado, recusar a operação de incorporação ou simplesmente exercer o direito de recesso, não havendo, em qualquer das opções, contrariedade ao princípio da realidade do capital social.

Em vista dos diferentes interesses tutelados, o objetivo das regras previstas no artigo $8^{\circ}$ da Lei das Sociedades Anônimas em relação às incorporações, e, portanto, dos trabalhos de avaliação realizados pelos auditores independentes, é o de garantir a correlação entre o valor final apurado e o valor do patrimônio da sociedade a ser incorporada. E a consequência da avaliação adequada será a correta definição do valor aumento do capital social e da relação de substituição das ações das companhias envolvidas.

Discute-se, entretanto, se a referida correlação significa avaliar a companhia incorporada a um valor justo ou simplesmente verificar se o seu valor corresponde, no mínimo, ao valor da conferência (aumento) de capital social na companhia incorporadora.

De acordo com a primeira corrente, apesar de a Lei das Sociedades Anônimas não mencionar o conceito de justa avaliação, a aplicação analógica do regime do artigo $8^{\circ}$ da mesma lei regula a avaliação com o fim de tutelar não somente os interesses dos credores, mas de todas as outras partes envolvidas na operação de incorporação ${ }^{195}$.

195 CARVAlHOSA, Modesto. Comentários, op. cit., v. 4, t. 1, p. 264. 
Contrariamente, há quem entenda que a Lei das Sociedades Anônimas em nenhum dispositivo faz menção ao conceito de "justa avaliação" do patrimônio líquido da sociedade incorporada ou de quaisquer ativos a serem vertidos à companhia, sendo que o seu artigo 226 dispõe tão somente que a função dos avaliadores é a de verificar se o patrimônio líquido da companhia incorporada corresponde, no mínimo, ao valor do capital a ser realizado. Conforme LAMY FILHO e BULHÕES PEDREIRA,

a LSA não prescreve a avaliação segundo determinados critérios nem se refere a uma "justa avaliação". A função dos peritos, segundo o artigo 226 da LSA, é verificar se o valor do patrimônio líquido a ser vertido é ao menos igual ao valor do capital social que, segundo o protocolo, será formado na operação. ${ }^{196}$

No mesmo sentido, GUERREIRO entende que,

Os cuidados com que a lei cerca o procedimento estimatório visa evitar a valorização excessiva dos bens conferidos. Essa, não é outra, é a preocupação do legislador.

[...]

É imperioso reconhecer, pois, que uma avaliação conservadora dos bens capitalizados não afronta os interesses nem dos acionistas (desde que com ela concordem, em assembleia geral), nem de terceiros que se relacionam ou venham a se relacionar com a companhia. ${ }^{197}$

Para tal corrente, portanto, o princípio da realidade do capital social previsto no artigo 226 da Lei das Sociedades Anônimas legal serviria somente para resguardar o interesse dos credores em eventuais casos de superavaliação do patrimônio líquido da sociedade a ser incorporada ${ }^{198,199}$, evitando-se a emissão, pela incorporadora, das chamadas watered stocks ${ }^{200,201}$.

${ }^{196}$ LAMY FILHO, Alfredo; PEDREIRA, José Luiz Bulhões. Direito.. cit., v. 2, p. 1780.

197 GUERREIRO, José Alexandre Tavares. Sobre a conferência de bens. Revista de Direito Mercantil, Industrial, Econômico e Financeiro, ano XXI, n. 48, p. 19-20. São Paulo: RT, out./dez. 1982.

198 "O objetivo da lei comercial é, portanto, impedir que o bem (ou o patrimônio líquido) forme capital social por valor superior ao real. Se as partes acordam em transmiti-lo por valor inferior, não há o que objetar: ao contrário, quanto mais subavaliado o bem ou o patrimônio líquido, maior a garantia dos credores, que é a razão de ser do requisito legal de avaliação." LAMY FILHO, Alfredo; PEDREIRA, 
Finalmente, há de se relembrar que, na operação de incorporação, o laudo de avaliação será possivelmente elaborado com base nas demonstrações financeiras da companhia incorporada, razão pela qual as regras relativas às demonstrações financeiras e à elaboração dos pareceres dos auditores independentes, analisadas nos subcapítulos 4.2.1.1 e 4.2.1.3 supra, serão essenciais também para o desfecho da avaliação.

4.2.2.3. Os possíveis critérios de avaliação da companhia incorporada e a decisão acerca da sua utilização

José Luiz Bulhões. A Lei das S.A.: pressupostos, elaboração, aplicação. 3. ed. Rio de Janeiro: Renovar, 1997, p. 563.

199 Conforme GUERREIRO, ao comentar não especificamente sobre a avaliação nas operações de incorporação, mas sobre a avaliação de quaisquer bens quando da sua conferência para um aumento de capital: "O que se conclui, desde logo, é que a tendência natural dos subscritores consiste na superavaliação - e, por isso a lei, em todos os sistemas jurídicos, se orienta no sentido de contê-la. Por conseguinte, se os conferentes de bens concordam em lhes atribuir valores conservadores, com isso não objetivam qualquer objetivo ilícito, no que tange às relações jurídicas de direito privado e às normas de ordem pública que presidem a organização e o funcionamento das sociedades anônimas". Sobre a conferência de bens. Revista de Direito Mercantil, Industrial, Econômico e Financeiro, ano XXI, n. 48, p. 19. São Paulo: RT, out./dez. 1982.

${ }^{200}$ KLEIN, William A.; COFFEE JR., John C.; PARTNOY, Frank. Business organization, op. cit., p. 225230.

201 No direito espanhol, parece ser essa também a posição de GARRIGUES e URÍA, segundo os quais "las aportaciones no dinerarias encierran siempre el peligro de traducir en cifra de capital aportaciones ficticias o valoradas con exceso; y que este peligro abre la posibilidad de que la sociedad nazca a la vida del Derecho con un patrimonio de valor inferior al que indica la cifra Del capital, con el consiguiente engaño para los acreedores y para los futuros accionistas. Los aportantes suelen aspirar a obtener el precio más alto posible de una cosa, de la que les sería difícil desprenderse en el mercado o de la que sólo podrían desprenderse a un precio más bajo". GARRIGUES, Joaquin; URÍA, Rodrigo. Comentarios a la ley de sociedades anónimas, t. 1. Madrid: Instituto de Estudios Politicos, 1952, p.329.

Já no direito italiano, a mesma posição adota FERRI, segundo o qual "La preoccupazione Del legislatore non è quella della sottovalutazioni, perchè è questo il criterio a cui esso stesso si ispira; la preoccupazione del legislatore è quella di impedire le sopravvalutazioni, perchè è attraverso queste chi si può progressivamente annulare il valore capitale e ciò̀ al tempo stesso la garanzia dei creditori e l'elemento centrale, la base stessa della organizzazione sociale capitalistica. Attennendo il capitale sociale all'essenza dell'istituto e costituendo la base di una struttura organizzativa capitalista nei rapporti interni e nei rapporti con i terzi, la conservazione del capitale sociale è esigenza imprescindibile e principio inderogabile delle società di capitali." FERRI, Giuseppe. Le società. Torino: Torinese, 1971, p. 555 . 
As discussões sobre escopo da avaliação da companhia incorporada e a consequente tutela das partes interessadas justificam-se pela premissa de que não existe um único e definitivo valor da companhia, mas um valor aceitável de acordo com uma correta análise procedida com base em um método aceito. Portanto, tal avaliação poderá ocorrer mediante diferentes métodos ou critérios existentes, de forma que a definição do valor final do acervo dependerá da escolha do critério mais adequado a ser utilizado em cada hipótese, ou mesmo da conjugação de diferentes critérios.

Tomemos como exemplo o caso de uma companhia que possui imóveis como principais ativos e nenhuma operação ou contratos comerciais celebrados. As atuais normas brasileiras de contabilidade, como regra, obrigam que, se tal companhia não possui como objeto social o investimento em imóveis, tais imóveis deverão ser contabilizados a preço de custo, e não poderão ser reavaliados pelo valor de mercado ${ }^{202}$. Isso quer dizer que, no futuro, a avaliação dessa companhia sob o critério do valor patrimonial deverá refletir um valor desatualizado, muito menor do valor que se auferiria se a avaliação fosse realizada de acordo com o critério do valor contábil ajustado a preços de mercado. Ainda, a avaliação dessa mesma companhia realizada de acordo com critérios econômicos, como a comparação por múltiplos ou o fluxo de caixa descontado, provavelmente indicaria um valor consideravelmente baixo, considerando-se a reduzida perspectiva de rentabilidade ${ }^{203}$.

Trata-se, portanto, de questão central para a operação de incorporação e para a definição da responsabilidade do auditor independente, enquanto avaliador, a discussão acerca da discricionariedade dos acionistas e administradores da companhia incorporadora ou mesmo dos avaliadores em relação à escolha dos critérios de avaliação. Em outras palavras, quem determina quais serão os critérios utilizados: os acionistas e

202 Conforme item 16, “c” da Deliberação CVM n” 27/86.

203 Conforme DAMODARAN, "se você avaliar uma empresa usando modelos de fluxo de caixa descontado $e$ de avaliação relativa, pode muito bem obter diferentes respostas usando os dois: a empresa pode ser subvalorizada no modelo de avaliação relativa e supervalorizada no modelo de fluxo de caixa descontado". DAMODARAN, Aswath. Avaliação de investimentos: ferramentas e técnicas para a determinação do valor de qualquer ativo. Trad. Kleber Nunes, ver. Eduardo Fortuna e José Rabello de Moraes. 2. ed. Rio de Janeiro: Qualitymark, 2009, p. 1019. 
administradores que negociam o protocolo de incorporação ou o auditor independente quando responsável pela avaliação?

No subcapítulo anterior discutiu-se o objetivo da avaliação, demonstrando-se que há uma corrente doutrinária favorável à obtenção do valor justo, de forma a tutelar diferentes interesses e outra que entende que a Lei das Sociedades Anônimas tutela somente a superavaliação, de forma a proteger os interesses dos credores. E tal discussão serve exatamente como premissa para a questão da discricionariedade acerca da utilização dos critérios de avaliação da companhia a ser incorporada.

Favorável à teoria da justa avaliação, entendida como a real avaliação, CARVALHOSA entende que não há liberdade de escolha dos critérios. Conquanto nenhum dispositivo legal imponha a utilização de um ou outro critério de avaliação, o fato de a avaliação objetivar a apuração do valor real do patrimônio líquido da companhia incorporada significa que não se deve escolher entre um ou outro critério, mas utilizá-los de forma a melhor atingir tal objetivo. Conforme o autor,

\begin{abstract}
Assim, não se pode concluir pela liberdade de escolha de critérios (valor real e de mercado $\mathrm{x}$ valor de balanço) somente porque este será tendencialmente menor do que aquele. Tal liberdade não é autorizada pela lei, que determina a avaliação dos patrimônios envolvidos pelos peritos nomeados. A nomeação deles é obrigatória. Por outro lado, a avaliação pelo balanço dispensaria inteiramente a formulação do respectivo laudo. A função dos peritos seria, no caso, inexistente. E não se pode admitir que a lei possa estipular situações jurídicas inúteis. Em conseqüência, entendemos que a garantia dos credores repousa na real avaliação dos patrimônios das sociedades envolvidas para a verificação do seu valor líquido. ${ }^{204}$
\end{abstract}

A consequência de tal corrente, portanto, é o aumento da competência, e, consequentemente, do âmbito de responsabilidade dos auditores independentes, que deverão não somente proceder a uma avaliação técnica de acordo com um determinado critério de avaliação, mas também escolher quais entre os possíveis critérios serão utilizados. 
De acordo com CLARK $^{205}$, a possibilidade de escolha dos critérios de avaliação aumenta a possibilidade de abusos por parte das partes que negociam a incorporação, razão pela qual a Accounting Principles Board Opinion No. 16/78 do American Institute of Certified Public Accountants (AICPA) foi emitida no sentido de eliminar tal discricionariedade.

\section{Contrariamente, LAMY FILHO e BULHÕES PEDREIRA ${ }^{206}$ entendem que os} sócios e administradores que negociam o protocolo de incorporação podem convencionar livremente os critérios de avaliação do patrimônio líquido da companhia incorporada, não havendo, na lei comercial ou na lei tributária, norma que lhes imponha o dever de adotar esse ou aquele critério ${ }^{207}$.

Entretanto, mesmo entendendo que o objetivo do avaliador seja simplesmente o de verificar se o valor do patrimônio líquido é ao menos igual ao valor do capital a realizar, os referidos autores não vedam totalmente a discricionariedade dos avaliadores em relação à escolha dos critérios, podendo eles discordar do que foi definido no protocolo de incorporação. De acordo com tais autores,

O valor determinado pelos avaliadores para os fins do artigo 226 da lei não coincide necessariamente com o fixado no protocolo, ou determinado

205 Conforme o autor, "Because there is validity in both of the concepts - a merger is a fusion or pooling of two businesses; a merger is an occasion when assets are revalued by parties bargaining at arms' length in a market transaction - it might seem that the accounting profession should be free to choose, on a case by case basis, which accounting methoed to employ for any given merger. But discretion creates possibilities of abuse. The most obvious is that corporate managers of acquiring companies will pressure their accountants to account for a merger by the pooling method when the acquired company's assets have increased over theis adjusted historical cost or book value but to use the purchase method when the acquired company's assets have declined bwloe book value.

[...]

Thus, discretion in the use of accounting methods has its problems. Because of them, Accounting Principles Board Opinion No. 16, adopted in 1970 and still in force, tries to eliminate discretion". CLARK, Robert Charles. Corporate law. Boston: Aspen, 1986, p. 411-412.

${ }^{206}$ LAMY FILHO, Alfredo; PEDREIRA, José Luiz Bulhões. A lei, op. cit., p.564.

207 No mesmo sentido, cf. Processo CVM RJ 2007/8844, rel. SEP, julgado em 23.07.2007. 
segundo os critérios nele ajustados, e a tarefa dos avaliadores nomeados pela Assembleia Geral pode compreender duas etapas bem distintas:

a) a determinação do valor convencional do patrimônio líquido da incorporada, segundo os critérios do protocolo; e

b) a determinação do valor que considerem correto, segundo os critérios que julgarem mais adequados, a fim de poderem declarar - como requerido no artigo 226 da lei - que o patrimônio líquido é, ao menos, igual ao montante do capital a realizar.

Essa segunda avaliação, com critérios escolhidos pelos avaliadores, somente existe se o protocolo fixa o valor do patrimônio líquido em números absolutos, ou se estipula critérios de avaliação que, no entender dos peritos, têm por efeito atribuir ao patrimônio líquido da incorporada valor maior do que o real. ${ }^{208}$

Não obstante a existência de discricionariedade acerca dos critérios de avaliação do patrimônio líquido da incorporada, o valor final a ser apurado dependerá da correta utilização de algum desses possíveis critérios, ou mesmo de sua conjugação. Nesse sentido, os subcapítulos seguintes serão dedicados a um breve estudo de cada um dos critérios de avaliação de companhias a serem utilizados pelos auditores independentes, bem como das suas especificidades em relação aos trabalhos desses profissionais.

\subsection{Avaliação a valor contábil}

A avaliação por valor contábil é a forma de aferição do valor contábil da companhia por meio dos valores registrados em seu balanço patrimonial, de acordo com as práticas contábeis brasileiras. Trata-se, portanto, de método de aferição do valor da companhia a ser incorporada por valor equivalente ao valor do seu patrimônio líquido contábil, sendo o critério mais utilizado ${ }^{209}$ nas operações de incorporação, em função dos efeitos fiscais que decorrem da reavaliação dos ativos e passivos da companhia ${ }^{210}$.

${ }^{208}$ LAMY FILHO, Alfredo; PEDREIRA, José Luiz Bulhões. A lei, op. cit., p.564.

209 Não obstante a discussão acerca da liberdade ou não de escolha dos critérios de avaliação, conforme abordado no subcapítulo 4.2.2.3 supra.

${ }^{210}$ LAMY FILHO, Alfredo; PEDREIRA, José Luiz Bulhões. Direito, op. cit., v. 2, p. 1780. 
Sobre o critério de avaliação a valor contábil, notam-se dois pontos essenciais. Em primeiro lugar, a avaliação deverá ser feita exclusivamente com base no balanço patrimonial, e não nas demais demonstrações financeiras da companhia incorporada. Conforme o item 16 da NPA n ${ }^{\circ} 14$ do IBRACON,

[...] nos trabalhos destinados à emissão de laudo de avaliação contábil em certa data-base, os procedimentos aplicados são principalmente direcionados aos valores constantes do balanço patrimonial, não sendo, portanto, direcionados a examinar as contas de resultado, as origens e aplicações de recursos e/ou as mutações havidas no patrimônio líquido durante o período findo na data-base do laudo de avaliação.

Em segundo lugar, ressalta-se que as demonstrações financeiras a serem utilizadas como base para a avaliação deverão ser elaboradas de acordo com as normas e práticas contábeis brasileiras, sobretudo aquelas relativas à data-base e tratamento posterior dos ativos e passivos avaliados.

Importante destacar, ademais, que o escopo dos trabalhos dos auditores independentes ultrapassa a mera aferição do valor patrimonial da companhia avaliada pela análise do seu balanço patrimonial, mesmo que tal balanço tenha sido auditado pelo próprio avaliador ou por outro auditor independente. Fosse somente esse o escopo dos trabalhos dos auditores independentes enquanto avaliadores, o legislador não precisaria exigir a elaboração de um laudo por especialistas (em contabilidade, no caso), uma vez que os balanços já são elaborados por profissionais contabilistas, e por vezes auditados por auditores externos. Conforme manifestação da $4^{\mathrm{a}}$ Câmara de Direito Privado do Tribunal de Justiça do Estado de São Paulo,

A transferência total das agências e equipamentos do BAS ao Sudameris pelo valor contábil não representa a melhor forma para aquilatar o valor justo. $\mathrm{O}$ valor patrimonial que deve ser apurado por peritos, constituiu-se em efetiva contraprestação pela transferência da titularidade daqueles ativos, tanto por tanto, para preservar o direito de todos os acionistas, majoritários ou minoritários.

Poderia ter sido feita a avaliação no procedimento de incorporação, mas o incorporador preferiu fazê-lo por valores escriturais dando azo ao justo reclamo do espólio pelo autor e, certamente, criando dificuldade até 
mesmo para apuração judicial do valor correto, sem que haja empobrecimento de qualquer das partes. ${ }^{211}$

Portanto, como a elaboração incorreta de um balanço patrimonial pela companhia impactará no resultado final da avaliação pelo auditor independente, os trabalhos de avaliação a critério contábil incluem, ademais, a verificação da adequação do próprio balanço patrimonial às regras contábeis.

Conforme determinação da NPA IBRACON $n^{\circ} 14$, caso o auditor independente tenha constatado a adoção de práticas contábeis equivocadas quando da elaboração do balanço patrimonial, ele deverá, no corpo do laudo de avaliação, incluir um parágrafo explicativo dos descumprimentos observados e, no anexo integrante do laudo, os componentes do balanço avaliados, apresentados pelos valores contabilizados nos livros, e os ajustes necessários para adequá-los às práticas contábeis adotadas no Brasil, sendo que o parágrafo de conclusão do laudo de avaliação deverá fazer menção explícita e exclusiva aos valores ajustados ${ }^{212}$.

Ao final, o laudo de avaliação deverá ser conclusivo no sentido de definir como valor da companhia incorporada, o valor patrimonial contábil verificado, observando na avaliação os devidos ajustes sobre a contabilidade anteriormente realizada.

\subsubsection{2. $\quad$ Avaliação a valor contábil ajustado a preços de mercado}

Outro critério contábil utilizado pelos auditores independentes para avaliação de uma sociedade a ser incorporada é o método do valor contábil ajustado a preços de mercado. Apesar de previsto no artigo 264 da Lei das Sociedades Anônimas como de

\footnotetext{
${ }^{211}$ Apelação 9097935-82.2003.8.26.0000, rel. Fábio Quadros, julgado em 09.06.2011.

${ }^{212}$ Item 24 do referido normativo.
} 
utilização obrigatória ${ }^{213}$ nos casos de incorporação de companhia controlada ou sob controle comum, tal critério pode ser utilizado em quaisquer operações de incorporação.

Tal critério consiste na utilização do método da avaliação a valor contábil, elaborada conforme subcapítulo anterior, porém ajustando-se o valor da avaliação pela mais-valia ou deduzindo-se pela menos-valia decorrente da avaliação dos ativos e passivos envolvidos a preços de mercado.

Devem ser abordados, pois, dois pontos essenciais sobre o presente critério. Em primeiro lugar, faz-se necessário discutir quem serão os profissionais responsáveis pela definição dos preços de mercado dos bens a serem reavaliados, de forma a possibilitar uma correta visualização do papel do auditor independente e a definição do âmbito da sua responsabilidade. Em segundo lugar, há que se discutir o próprio conceito de "valor de mercado" dos bens a serem reavaliados.

Sobre o primeiro ponto ${ }^{214}$, o valor de mercado dos ativos imobilizados poderá ser obtido a partir de um laudo de avaliação de especialistas em imóveis, o qual deverá ser submetido à assembleia geral da incorporadora juntamente com o laudo dos auditores independentes relativo ao acervo total da companhia. Em relação aos demais ativos e aos passivos, a definição do valor de mercado poderá ser feita de acordo com premissas assumidas pela administração, com apoio ou não de especialistas. Em ambos os casos, o laudo de avaliação dos auditores independentes deverá segregar os trabalhos dos demais peritos e as premissas da administração, para fins de segregação de responsabilidade.

Entretanto, conforme já abordado, relembramos que o parágrafo $1^{\circ}$ do artigo $8^{\circ}$ da Lei das Sociedades Anônimas não prevê qualificação técnica dos peritos ou empresa

213 Conforme exposto no subcapítulo 2.3.1 supra, a utilização obrigatória do critério de avaliação do valor patrimonial ajustado a preços de mercado nos termos do artigo 264 da Lei das Sociedades Anônimas não significa vincular a própria incorporação ou a definição da relação de substituição à sua adoção, mas significa, no mínimo, que esse critério será utilizado para fins de comparação e consequente referência para o cálculo do direito de retirada dos acionistas dissidentes da companhia incorporada.

${ }^{214}$ Cf. item 11 da NPA IBRACON n ${ }^{\circ} 14$. 
especializada avaliadora do acervo da companhia a ser incorporada que será vertido para a companhia incorporadora $^{215}$. Nesse sentido, o próprio auditor independente, munido de seu conhecimento prático sobre o assunto, pode ser contratado para determinar premissas e efetuar os cálculos do valor de mercado dos ativos e passivos a serem reavaliados, assumindo total responsabilidade pela avaliação, hipótese em que deverá detalhar no laudo de avaliação os critérios adotados para a conclusão em relação aos valores de mercado ${ }^{216}$.

Quanto ao conceito de "valor de mercado" dos bens suscetíveis a reavaliação em relação aos valores constantes do seu balanço patrimonial, especificamente sobre os ativos, a Lei das Sociedades Anônimas, em seu artigo 183, §1 $1^{\circ}$, define parâmetros para a sua aferição, ao dispor que,

Para efeitos do disposto neste artigo, considera-se valor justo:

a) das matérias-primas e dos bens em almoxarifado, o preço pelo qual possam ser repostos, mediante compra no mercado;

b) dos bens ou direitos destinados à venda, o preço líquido de realização mediante venda no mercado, deduzidos os impostos e demais despesas necessárias para a venda, e a margem de lucro;

c) dos investimentos, o valor líquido pelo qual possam ser alienados a terceiros.

d) dos instrumentos financeiros, o valor que pode se obter em um mercado ativo, decorrente de transação não compulsória realizada entre partes independentes; e, na ausência de um mercado ativo para um determinado instrumento financeiro:

1) o valor que se pode obter em um mercado ativo com a negociação de outro instrumento financeiro de natureza, prazo e risco similares;

2) o valor presente líquido dos fluxos de caixa futuros para instrumentos financeiros de natureza, prazo e risco similares; ou

3) o valor obtido por meio de modelos matemático-estatísticos de precificação de instrumentos financeiros. ${ }^{217}$

215 A respeito, cf. subcapítulo 4.2.2.1 supra.

${ }^{216}$ Cf. itens 12 e 13 da NPA IBRACON no 14 . O item 12 do referido normativo, entretanto, veda ao auditor independente a realização desse tipo de serviço de avaliação aos clientes que o contratou para o serviço de auditoria independente.

217 O parágrafo $1^{\circ}$ do artigo 183 da Lei das Sociedades Anônimas utiliza a expressão "valor justo" para referir-se ao chamado "valor de mercado". Pode-se inferir tal equivalência do texto do artigo 256, I, "b" do mesmo diploma legal, o qual dispõe o seguinte: "valor de patrimônio líquido (artigo 248) da ação ou quota, avaliado o patrimônio a preços de mercado (artigo 183, $\$ 1^{\circ}$ )" (grifo nosso). 
Mais simplificadamente, o artigo 465, $\S 1^{\circ}$ do Regulamento do Imposto de Renda (Decreto $\mathrm{n}^{\mathrm{o}}$ 3.000/99) define que "valor de mercado é a importância em dinheiro que o vendedor pode obter mediante negociação do bem no mercado".

Já o IBRACON, ao referir-se ao conceito de valor de mercado não somente dos ativos, mas também dos passivos da companhia a ser incorporada, entende que se deve seguir as normas e critérios aos quais o laudo de avaliação está associado ${ }^{218}$. Em segunda instância, caso tais normas associadas não possibilitem a definição de um valor de mercado, o item 14 da NPA IBRACON no 14 determina que

[...] o valor de mercado pode ser aquele que se obteria com a negociação do ativo ou do passivo em um mercado ativo, em que comprador e vendedor tenham conhecimento do assunto e independência entre si, sem que corresponda a uma transação compulsória ou decorrente de um processo de liquidação.

Na hipótese de ausência de um mercado ativo para o ativo ou o passivo a ser reavaliado, o valor de mercado pode ser obtido utilizando-se como referência o valor que se obteria com a negociação no mercado ativo de outro bem de natureza, prazo e riscos similares ${ }^{219,220}$. Ainda, caso, não haja um mercado alternativo, o valor de mercado poderá ser obtido mediante os seguintes critérios ${ }^{221}$ :

${ }^{218}$ Item 14 da NPA IBRACON n ${ }^{\circ} 14$.

${ }^{219}$ Item 15 da NPA IBRACON no 14.

${ }^{220}$ O fundamento da utilização do método da comparabilidade de ativos semelhantes para a definição do valor de mercado de um bem reside na semelhança entre o retorno e o risco (volatilidade) que ambos os ativos proporcionam. "The solution to the initial problem of circularity and to the problem of determining what it that makes assets is determined by the amount and character of the returns that one can expect to derive from it. The value of an asset is a function of its expected net returns and the estimated volatility of those returns. Two assets are comparable if they have the same expected return and the same (volatility) risk". KLEIN, William A.; COFFEE JR., John C.; PARTNOY, Frank. Business organization and finance - legal and economic principles. New York: Foundation Press, 2010, p. 321.

${ }^{221}$ Item 15 da NPA IBRACON n ${ }^{\circ} 14$. 
a) cálculo do valor presente dos ativos e passivos que reflita avaliações do mercado quanto ao valor do dinheiro no tempo e com os riscos específicos, ao se tratar de ativos e passivos monetários.

b) cálculo do valor que seria obtido mediante a realização, até mesmo por venda, dos itens não monetários.

c) cálculo do valor das contingências (ativas e passivas que se qualifiquem para registro contábil segundo as práticas contábeis adotadas no Brasil).

d) determinação do passivo ou do ativo tributário, decorrente da maior ou menor valia, respectivamente, apurada em decorrência dos itens anteriores.

Infere-se, do exposto, que o critério de avaliação a valor contábil ajustado a preços de mercado pode ensejar diversas distorções por parte dos avaliadores, controladores e outros mancomunados em promover a subavaliação ou superavaliação da sociedade a ser incorporada. Isso porque os métodos acima expostos para a fixação do valor de mercado de um ativo funcionam apenas como parâmetros, possibilitando um juízo subjetivo quanto ao valor de mercado dos bens avaliados.

Portanto, mostram-se essenciais as disposições relativas à responsabilidade dos auditores independentes enquanto avaliadores, conforme será abordado no Capítulo 5 adiante.

4.2.2.3.3. Critérios não contábeis: (i) avaliação a valor de mercado, (ii) avaliação pelo fluxo de caixa descontado e (iii) avaliação pela comparação por múltiplos

A avaliação de companhias de acordo com critérios não contábeis não constitui atividade precípua de uma empresa especializada em contabilidade, nem tampouco está incluída no escopo de um serviço de auditoria independente. Entretanto, repita-se que, como a lei não estabelece parâmetros para a qualificação dos avaliadores como 
especialistas $^{222}$ e, como os auditores prestam uma diversidade de serviços de consultoria não contábil ${ }^{223}$ e possuem uma reconhecida expertise em operações de incorporação, não se pode afirmar ao certo que os próprios auditores independentes não são especializados na prestação de serviços de avaliação de companhias por critérios não contábeis.

Na prática, os grandes grupos de auditoria independente, por vezes utilizando-se de empresas pertencentes ao mesmo grupo econômico ${ }^{224}$, são responsáveis pela elaboração de diversos laudos econômicos para a avaliação de empresas não somente em operações de incorporação, mas também em demais hipóteses legais. Por tal razão, aliás, o item X.d.5 do Anexo III à Instrução Normativa CVM n 361, ao regular a atividade de avaliação econômica e contábil de companhia aberta ${ }^{225}$, dispõe que o laudo de avaliação deverá conter declaração do avaliador em relação aos "valores recebidos do ofertante e da companhia objeto, a título de remuneração por quaisquer serviços de consultoria, avaliação, auditoria e assemelhados [...]" (grifo nosso).

Nesse ponto, relembramos os deveres de objetividade, independência e competência profissional que orientam as atividades dos auditores independentes, conforme abordado nos subcapítulos 4.1.1 e 4.1.3 supra. Independentemente das consequências sobre a violação de tais deveres, deve-se fazer uma breve reflexão sobre os

${ }^{222}$ A respeito, cf. subcapítulo 4.2.2.1 supra.

${ }^{223}$ A despeito das normas de objetividade e independência analisadas no subcapítulo 4.1.1 supra.

${ }^{224}$ Sobre a elaboração de laudo de avaliação baseado em critérios econômicos realizada por partes relacionadas aos auditores independentes, ressalte-se que o artigo 23 da Instrução Normativa CVM $n^{\circ}$ 308/99 que dispõe impõe vedação expressa à prestação de serviços de avaliação de empresas não apenas pelos aos auditores, mas pelas empresas a eles ligadas. Conforme o texto do referido dispositivo "é vedado ao Auditor Independente e às pessoas físicas e jurídicas a ele ligadas, conforme definido nas normas de independência do CFC, em relação às entidades cujo serviço de auditoria contábil esteja a seu cargo, [...] II - prestar serviços de consultoria que possam caracterizar a perda da sua objetividade e independência. Parágrafo único. São exemplos de serviços de consultoria previstos no caput desse artigo, [...] II - avaliação de empresas"(grifo nosso).

${ }^{225}$ Conforme abordagem anterior, apesar de o Anexo III à Instrução Normativa CVM no $361 / 02$ fazer referência à hipótese de avaliação para fins de oferta pública para aquisição de ações, entendemos possível a aplicação analógica de tal dispositivo à hipótese de incorporação envolvendo companhias abertas. 
critérios não contábeis de avaliação, de forma a entender a atuação prática dos auditores independentes quando da utilização desses critérios no processo de avaliação.

O primeiro critério não contábil de avaliação da sociedade a ser incorporada é o do valor de mercado das ações, que é basicamente a utilização do valor de fechamento das ações da companhia a ser incorporada em uma determinada data-base como referência para a definição do seu "valor de mercado".

De acordo com LAMY FILHO e BULHÕES PEDREIRA,

A avaliação pelo critério das cotações em bolsa em geral é considerada a mais perfeita porque o valor não é opinião de um avaliador, ou de pequeno número de avaliadores, mas do conjunto dos participantes no mercado de ações, o que lhe confere maior grau de objetividade. ${ }^{226,227}$

Não concordamos, entretanto, com tal assertiva. Em primeiro lugar, porque a avaliação dos peritos, quando procedida de acordo com a melhor técnica, deve ser melhor do que a do mercado como um todo, considerando-se que os investidores que influenciam nas cotações das ações da companhia incorporada são por vezes assistidos por especialistas, e por vezes não.

Em segundo lugar, a decisão de comprar ou vender uma ação a um preço específico não é determinada apenas pelo interesse em pagar o "valor justo" conforme os critérios de avaliação de empresas, de forma que muitas vezes as cotações das ações das companhias abertas são determinadas mais por aspectos macroeconômicos estranhos ao desempenho e ao status da companhia.

${ }^{226}$ LAMY FILHO, Alfredo; PEDREIRA, José Luiz Bulhões. Direito, op. cit., v. 2, p. 1779.

227 Ainda, conforme Eizirik, "caso a companhia sucedida tenha ações negociadas em Bolsa de Valores em volume tal que possam ser tidas como de alta liquidez, o critério mais adequado para avaliar o seu patrimônio será o do valor de mercado". EIZIRIK, Nelson. A lei das S/A comentada, v. 3. São Paulo: Quartier Latin, 2011, p. 241. 
Por outro lado, é inegável que a avaliação baseada no valor de mercado da companhia a ser incorporada possui a vantagem de demonstrar um valor final mais atualizado do que os critérios contábeis, que utilizam como base balanço patrimonial não necessariamente atualizado, conforme abordagem anterior ${ }^{228}$.

Há de se ressaltar, finalmente, que o critério da cotação das ações em bolsa tem como restrição a liquidez das ações da companhia aberta incorporada no mercado de valores mobiliários, visto que as ações com baixo volume de negociação podem não demonstrar nem mesmo o preço de mercado correto que se pagaria, quanto mais determinar o justo valor de avaliação da companhia. Por tal motivo, o artigo 11 da Instrução CVM no 319/1999 prevê a vedação de adoção de tal critério para a definição das relações de substituição de ações dos acionistas não controladores quando as companhias envolvidas não integrarem índices gerais representativos de carteira de ações admitidos à negociação em bolsas de futuros.

Já os critérios de avaliação de acordo com o fluxo de caixa descontado e pela comparação por múltiplos são considerados duas formas de avaliação a valores econômicos, pois de acordo com estes se pretende determinar o valor da companhia exclusivamente em função da sua capacidade de gerar lucros, i.e., dos seus resultados econômicos ${ }^{229}$.

O critério do fluxo de caixa descontado consiste na avaliação da companhia utilizando-se como referência o retorno futuro esperado, portanto, o seu potencial de geração de lucros no futuro. Para tanto, utiliza-se a somatória dos valores dos fluxos de

${ }^{228}$ Cf. subcapítulo 4.2.1.1 supra.

229 Tais critérios, entretanto, diferem sob a perspectiva e o parâmetro de análise. Segundo DAMODARAN, "na avaliação de fluxo de caixa descontado, assumimos uma perspectiva de longo prazo, examinamos os fundamentos de uma empresa em detalhes, e tentamos estimar um valor intrínseco para a empresa. Na avaliação relativa, presumimos que o mercado, na média, esteja certo e estimamos o valor para a empresa verificando como as similares são cotadas". DAMODARAN, Aswath. Avaliação de investimentos: ferramentas e técnicas para a determinação do valor de qualquer ativo. Trad. Kleber Nunes, ver. Eduardo Fortuna e José Rabello de Moraes. 2. ed. Rio de Janeiro: Qualitymark, 2009, p. 1012. 
caixa livres da empresa (FCLE) anuais trazidos ao valor presente ${ }^{230}$, (i) considerando-se (a) um determinado período em que se pode objetivamente projetar as receitas da companhia avaliada e (b) um período de perpetuidade ${ }^{231}$, caso a companhia possua prazo indeterminado e perspectiva eterna de geração de lucro, e (ii) descontando-se o custo médio ponderado de capital $\left(\mathrm{WACC}^{232}\right)$.

${ }^{230} \mathrm{O}$ valor presente líquido (VPL) é uma metodologia desenvolvida pela matemática financeira para determinar o valor presente de pagamentos futuros descontados a uma taxa de juros determinada. Conforme DAMODARAN, Aswath. Avaliação, op. cit., p. 12,

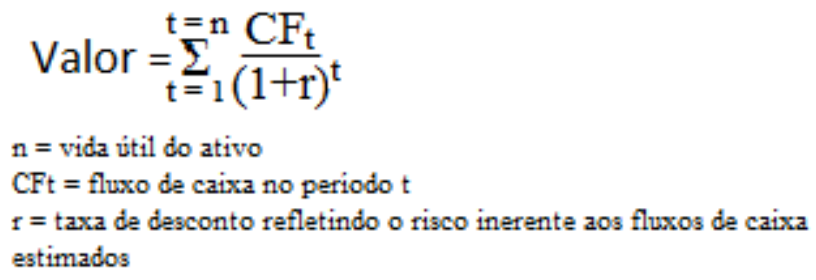

${ }^{231}$ O conceito de perpetuidade foi criado para representar o período infinito em que se projeta eterna geração de lucro pela companhia, em relação ao qual serão somadas as FCLEs por meio do método do valor presente líquido (VPL). O cálculo da somatória dos FCLEs no período de perpetuidade (denominado valor residual, ou valor final) pressupõe a taxa de crescimento dos fluxos de caixa (g) como constante e é obtida por meio da seguinte fórmula:

$$
\begin{aligned}
& \text { VR }=\frac{\text { FCLEn } \times(1+g)}{\text { WaCC }-g} \\
& \text { VR= valor residual } \\
& \text { FCLE = fluxo de caixa livre da empresa } \\
& \text { wacc = custo médio ponderado de capital } \\
& g=\text { taxa de crescimento dos fluxos de caixa na perpetuidade }
\end{aligned}
$$

Conforme DAMODARAN, "o valor de uma empresa é o valor presente de seus fluxos de caixa esperados ao longo de sua vida. Visto que as empresas têm vidas infinitas, aplicamos um fechamento a uma avaliação pela estimativa de fluxos de caixa por um período e, então, estimamos um valor para a empresa ao fim do período - um valor final. [...] Se imaginarmos que as empresas tenham vidas infinitas, uma abordagem que seja mais coerente com a avaliação de fluxo de caixa descontado é supor que os fluxos de caixa da empresa crescerão a uma taxa constante perpetuamente, além do limite do tempo". DAMODARAN, Aswath. Avaliação de investimentos: ferramentas e técnicas para a determinação do valor de qualquer ativo. Trad. Kleber Nunes, ver. Eduardo Fortuna e José Rabello de Moraes. 2. ed. Rio de Janeiro: Qualitymark, 2009, p. 334. A respeito, cf. ainda MATIAS, Alberto Borges (et. al.). Análise financeira fundamentalista de empresas. São Paulo: Atlas, 2009, p. 322-323.

232 Sigla em inglês que representa o weighted average cost of capital, i.e., a taxa de atratividade calculada pela ponderação entre os juros devidos aos credores da companhia (dívida) com a expectativa de rentabilidade dos seus próprios acionistas (capital próprio), proporcionalmente ao peso das dívidas e do capital próprio no balanço da companhia. 
O cálculo do FCLE, por sua vez, é realizado com base no lucro operacional da companhia (representado pelas siglas LAJIR ou EBIT ${ }^{233}$ ) constante na sua demonstração de resultado, somando-se os valores relativos à depreciação e amortização no período, e subtraindo-se os seguintes valores: (i) impostos sobre o lucro operacional, (ii) investimentos necessários em ativos imobilizados $\left(\mathrm{CAPEX}^{234}\right)$, e (iii) investimentos com capital de giro $^{235}$, todos considerados nos mesmo período de apuração do lucro operacional.

O método de avaliação por múltiplos consiste na avaliação da companhia por meio da multiplicação do valor obtido como múltiplo do seu valor de mercado ${ }^{236}$ (enterprise value $)^{237}$ sobre determinado valor de referência que, de preferência, represente a capacidade de geração de lucro operacional da companhia (geralmente o EBITDA ${ }^{238,239}$ ), pelo valor médio obtido dos múltiplos de empresas comparáveis, em regra, do mesmo setor da economia.

${ }^{233}$ Em português e em inglês, respectivamente, Lucro Antes dos Juros e Impostos sobre a Renda incluindo Contribuição Social sobre o Lucro Líquido e Earnings Before Interest and Taxes. A respeito, cf. Instrução $\mathrm{CVM} \mathrm{n}^{\circ}$ 527, de 04 de outubro de 2012.

${ }^{234}$ Sigla em inglês para Capital Expenditures. Em regra, o valor dos investimentos necessários em ativos imobilizados relaciona-se ao grau de depreciação dos seus ativos imobilizados, dentro de uma perspectiva de crescimento de estabilidade da companhia. Nesse sentido, por exemplo, se houver interesse na manutenção do crescimento da companhia, o seu investimento anual em CAPEX deverá ser equivalente ao montante da depreciação auferida no período.

${ }^{235}$ O investimento em capital de giro (ICG), por sua vez, é obtido por meio da seguinte fórmula:

$$
\mathrm{ICGt}=\frac{\mathrm{CF}}{360} \times(\text { VENDASt }- \text { VENDASt-1) }
$$

$\mathrm{CF}=$ Ciclo Financeiro, calculado pela soma entre o prazo médio de recebimento dos recursos das vendas (PMR) e o prazo médio de entrega (venda) dos produtos (PME), subtraidos do prazo médio de pagamento dos fornecedores (PMP)

236 Que pode ser calculado somando-se o valor de mercado com a dívida líquida da companhia.

${ }^{237}$ Ou do seu equity value, se a avaliação for feita sob a perspectiva do acionista, considerando-se equity value o valor de mercado das ações vezes o número de ações em circulação da companhia.

${ }^{238}$ Em português e em inglês, respectivamente, Lucro Antes dos Juros, Impostos sobre Renda incluindo Contribuição Social sobre o Lucro Líquido, Depreciação e Amortização e Earnings Before Interest, Taxes, Depreciation And Amortization. A respeito, cf. Instrução CVM nº 527, de 04 de outubro de 2012.

${ }^{239}$ No caso de avaliação sob a perspectiva do acionista (equity value), os múltiplos da companhia avaliada e das companhias comparáveis serão obtidos pela divisão do equity value por algum indicador operacional que se refira a um momento pós-dívida, como o lucro líquido ou até mesmo o patrimônio líquido. 
A avaliação por múltiplos poderá ser realizada com base (i) nos múltiplos de negociação, que são fundamentados no valor de mercado das ações, (ii) nos múltiplos precedentes, que são fundamentados nas operações equivalentes de empresas comparáveis.

Portanto, a avaliação por múltiplos baseia-se na comparação entre múltiplos (resultados) da companhia avaliada com os múltiplos de outras companhias do mesmo setor. Eis aqui o primeiro questionamento que pode ser apontado na avaliação sob tal critério: a comparabilidade entre as empresas base da avaliação. Pode-se, ademais, questionar o indicador econômico que foi utilizado como referência para a obtenção dos múltiplos das companhias e, portanto, para a comparação entre elas, pois há diferentes indicadores representantes da capacidade de geração de lucro da companhia.

Por fim, ressalte-se que, conquanto os critérios do fluxo de caixa descontado e o da avaliação por múltiplos não sejam critérios contábeis de avaliação, as projeções e perspectivas de rentabilidade baseiam-se em grande parte nas demonstrações financeiras da companhia avaliada, as quais serão objeto de revisão pelos auditores independentes, nos casos de companhias abertas. Há, entretanto, grande discricionariedade do avaliador em relação às inúmeras variáveis matemático-financeiras adicionais utilizadas como referências para as avaliações econômicas, o que não raro implica distorções e divergências sobre os laudos de avaliação elaborados pelas empresas especializadas.

\subsubsection{Características do laudo de avaliação}

Conforme abordagem do subcapítulo 4.2.2.1 acima, o parágrafo $1^{\circ}$ do artigo $8^{\circ}$ da Lei das Sociedades Anônimas prevê que a forma de apresentação da avaliação do patrimônio líquido da companhia incorporada a ser vertido à incorporadora será necessariamente um laudo de avaliação, o qual deverá conter, no mínimo, a indicação dos critérios de avaliação e dos elementos de comparação adotados.

Trata-se, pois, de importante inovação em relação ao regime anterior, pois o parágrafo $1^{\circ}$ do artigo $5^{\circ}$ do Decreto-Lei $2.627 / 40$ não previa requisitos mínimos dos 
laudos de avaliação, fato que possibilitava eventuais erros e/ou fraudes na avaliação pelos interessados.

Ademais, o artigo $8^{\circ}$ da Lei das Sociedades Anônimas manteve disposição do parágrafo $1^{\circ}$ do artigo $5^{\circ}$ do Decreto-Lei $2.627 / 40$ no sentido de que os laudos deverão ser instruídos com os documentos relativos aos bens avaliados, como, por exemplo, as demonstrações financeiras da companhia auditada, eventuais laudos periciais relativos a ativos e passivos específicos, entre outros.

\subsubsection{A dupla avaliação e a relação de substituição prevista no artigo 264 da Lei das Sociedades Anônimas}

Conforme abordagem anterior, a incorporação de companhia controlada é uma hipótese especial em que há uma situação de conflito entre os acionistas que deliberarão sobre a incorporação e, possivelmente, dos administradores das companhias envolvidas, além de possuir peculiaridades contábeis como a desconsideração do investimento na sociedade controlada para fins de avaliação e aumento de capital quando ambos os patrimônios líquidos sejam avaliados sob os mesmos critérios e com a mesma data-base.

Por tais motivos, o artigo 264 da Lei das Sociedades Anônimas impõe, para fins de comparação e definição do preço de retirada dos acionistas minoritários dissidentes, a elaboração de uma justificação que contenha o cálculo das relações de substituição com base na avaliação a preço de mercado de ambos os patrimônios líquidos das companhias envolvidas (ou outro critério autorizado pela CVM, conforme será abordado mais adiante).

Exige-se, portanto, a elaboração de dois laudos de avaliação: um a valor contábil para fins de registro contábil da operação e outro a preço de mercado, para fins de comparação e cálculo do valor de retirada ${ }^{240}$.

240 “a consequência do dispositivo legal comentado no parágrafo anterior é que, em termo práticos, nas combinações envolvendo entidades sob controle comum, sempre existirão dois laudos de avaliação: um 
Ressalte-se que tal exigência legal é custosa e pode demandar muito tempo, pois requer avaliação de ambas as sociedades envolvidas e a reavaliação de diversos ativos e passivos, razão pela qual os acionistas majoritários tendem a postular a possibilidade de elaboração do laudo comparatístico baseado em critério alternativo àquele previsto no artigo 264 da Lei das Sociedades Anônimas. Sobre o referido artigo, aliás, importa mencionar que a expressão "valor de mercado" contida em seu caput faz referência à avaliação segundo o critério técnico-contábil de valor contábil ajustado a preços de mercado, acima explicado, e não a qualquer outra forma de avaliação (econômica, sobretudo) que reflita o valor que se obteria no mercado em uma alienação ou qualquer hipótese congênere.

Nesse sentido, não é correta a interpretação segundo a qual o dever imposto pelo referido artigo é satisfeito quando da utilização de um critério de avaliação diverso, como o fluxo de caixa descontado, conforme julgou a $4^{\text {a }}$ Câmara de Direito Privado do Tribunal de Justiça do Estado de São Paulo:

O que o legislador quis, ao falar em "preços de mercado", nas avaliações impostas pelo artigo 264, foi a determinação de valor real do patrimônio líquido das companhias, do seu ativo, com dedução do passivo. Avaliações em que a dever preponderar o caráter individual dos bens e direitos, tangíveis e intangíveis.

[...]

Assim, o que pesou na avaliação dos patrimônios líquidos, a macular o procedimento da incorporação, não foram as não comprovadas manipulações na contabilidade das empresas nem emprego de critérios diferentes de avaliação, mas sim a utilização do método de fluxo de caixa descontado, no cálculo das relações de substituição das ações, na oportunidade de atendimento do que estava a rezar o artigo 264 da Lei das S.A. Com isso, como constou em outra parte, "Ao invés de se apurar o valor de mercado, averiguou-se o valor econômico através do sistema

para efeito de registro contábil da operação, em que ativos e passivos são avaliados aos seus valores de livros; outro para efeito de cálculo das relações de substituição de ações, em que ativos e passivos são avaliados em outra base”. IUDÍCIBUS, Sérgio de (et. al.). (FIPECAFI) Manual de contabilidade, op. cit., p. 416. 
de fluxo de caixa descontado, o que inviabilizou a realização da comparação. $^{241}$ (grifo nosso)

O colegiado da CVM, em sentido contrário, decidiu pela possibilidade de utilização do critério do fluxo de caixa descontado ${ }^{242}$ e até mesmo do próprio critério do valor contábil $^{243}$ alternativamente à imposição legal de utilização do critério do valor contábil ajustado a preços de mercado, sem, contudo, deixar de realizar análise casuística quanto ao uso dos diferentes critérios de avaliação para atendimento do disposto no artigo 264 da Lei das Sociedades Anônimas.

No Processo CVM RJ 2007/4933 ${ }^{244}$, as partes consulentes pretendiam atender ao artigo 264 da Lei das Sociedades Anônimas por meio da avaliação da companhia incorporadora e das incorporadas conforme o método do patrimônio líquido contábil, uma vez que a incorporação seria efetivamente realizada avaliando-se a companhia incorporada de acordo com o método do fluxo de caixa descontado (e a incorporadora ao critério do valor de mercado). Nesse caso, o Colegiado da CVM, acompanhando manifestação da área técnica, não aceitou a utilização do critério do valor contábil como alternativa ao critério do patrimônio líquido a preços de mercado, por entender que,

241 Apelação Cível no 510.984-4/8, rel. Desembargador José Geraldo de Jacobina Rabello, julgado em 26.06.2008. Conforme bem disposto nas contra-razões aceitas no referido pleito, "Incidiu em erro o laudo pericial, portanto, ao admitir que o valor econômico apurado estava a refletir um critério de apuração do valor de mercado dos bancos, quando o que o método de fluxo de caixa descontado tem como proposta é retratar o potencial econômico dos itens patrimoniais de determinado empreendimento, inclusive do "goodwill" (cf. Noronha, "Legal Dictionary - Dicionário Jurídico": fundo de comércio, luvas, aviamento, conceito na praça). Não se podia, pois, com a aplicação do método de fluxo de caixa descontado, se entender, no caso, que se estava em face de uma avaliação das companhias a preços de mercado, como obrigatoriamente estabelecido no artigo 264 da lei, considerada a redação em vigor na época da incorporação" (grifo nosso).

242 Processo CVM RJ 2009/7847, rel. SEP, julgado em 01.09.2009; Processo CVM RJ 20070/4933, rel. SEP, julgado em 19.06.2007; Processo CVM RJ 2006/3160, rel. SEP, julgado em 30.05.2006; e Processo CVM RJ 2006/0856, rel. SEP, julgado em 21.02.2006.

243 Processos CVM RJ 2010/11451, rel. SEP, julgado em 01.08.2010; RJ 2009/6414, rel. SEP, julgado em 29.09.2009; e RJ 2009/10687, rel. DSW, julgado em 23.10.2007.

244 Processo CVM RJ 2007/4933, rel. SEP, julgado em 19.06.2007. 
a) o valor contábil não é uma informação nova para o acionista, uma vez que as demonstrações financeiras das companhias, por serem companhias abertas, são publicadas e divulgadas ao mercado e, portanto, não agregaria valor para formar sua opinião ${ }^{245}$; e que

b) se as relações de substituição dos acionistas não controladores, previstas no protocolo de incorporação, forem menos vantajosas que as resultantes da comparação prevista no caput do art. 264 da LSA, seria subtraída do acionista dissidente a opção de ser reembolsado nos termos do art. 45 da Lei n ${ }^{\circ}$ 6404/76 (leia-se pelo valor contábil, no caso do BESC) ou por outro valor que seria apurado de acordo com o caput do art. 264, conforme disposto no seu $\S 3^{\circ}$, dado que ambos seriam os mesmo. ${ }^{246}$

No mesmo caso, consolidou-se o entendimento de que o uso do critério dos preços de mercado não é adequado quando as ações da companhia avaliada possuírem baixa liquidez ${ }^{247}$.

Já no Processo CVM 2009/7847, a área técnica da CVM, em entendimento aprovado pelo seu Colegiado, possibilitou alternativamente o uso do critério do fluxo de caixa descontado para fins de comparação, mas com a ressalva de que a avaliação deveria ser suportada por um laudo com data base atualizada, ao contrário do solicitado pelas partes consulentes.

245 Esse argumento foi também utilizado pela CVM no Processo CVM RJ 2006/3160 para impedir a utilização do critério do patrimônio líquido como alternativa ao do patrimônio líquido a preços de mercado. Conforme voto do diretor Pedro Oliva Marcilio de Sousa, "no caso concreto, a utilização do patrimônio líquido contábil não preencheria esse objetivo (produção de nova informação), dado que, por serem companhias abertas, a legislação vigente já determinada que elas divulguem demonstrações financeiras que apresentam o valor contábil de ambas, sujeitas a auditoria independente. Ou seja, autorizando-se que o critério alternativo ao estabelecido no caput fosse o patrimônio líquido contábil, o objetivo do art. 264 seria frustrado no caso concreto". Processo CVM RJ 2006/3160, rel. SEP, julgado em 30.05.2006.

${ }^{246}$ Conforme item 18 do Relatório de Análise/CVM/SEP/GEA-3/No 031/07.

247 Conforme voto do diretor Pedro Oliva Marcilio de Souza no Processo CVM RJ 2006/3160, "tendo em vista a escassa liquidez das ações da companhia incorporada, parece-me que a avaliação de ambas as sociedades pelo fluxo de caixa descontado é o melhor critério para a comparação da relação de substituição". Processo CVM RJ 2006/3160, rel. SEP, julgado em 30.05.2006. 
A utilidade e a aplicabilidade de cada critério dependem das circunstâncias envolvidas em cada operação específica, sendo impossível uma conclusão geral e objetiva quanto ao melhor critério a ser utilizado para o cumprimento do artigo 264 da Lei das Sociedades Anônimas. Entende-se, portanto, que a utilização de critérios alternativos ao do valor contábil ajustado a preços de mercado deve ser feita em vista do interesse dos minoritários em cada específica operação de incorporação, devendo a CVM somente autorizar a utilização de tais critérios alternativos quando forem mais benéficos para os minoritários, i.e., quando a avaliação implicar um valor maior que servirá como base para o cálculo do valor de retirada para os acionistas dissidentes.

\subsubsection{A participação dos auditores independentes nas assembleias gerais de incorporação}

Sendo o perito contratado para a avaliação da companhia incorporada um auditor independente, dispõe o parágrafo $1^{\circ}$ do artigo $8^{\circ}$ da Lei das Sociedades Anônimas que este deverá comparecer à assembleia geral (de incorporação) que deliberará sobre o laudo de avaliação elaborado, a fim de prestar as informações que lhe forem solicitadas.

Tal regra não é novidade no direito brasileiro, já constando do parágrafo $1^{\circ}$ do artigo $5^{\circ}$ do revogado Decreto-Lei 2.627/40, e tem como fim a explicação do conteúdo técnico do laudo e demais questões relativas aos trabalhos de avaliação realizados. Isso porque os acionistas que deliberarão sobre o laudo de avaliação (e sobre a operação de incorporação em si) possivelmente não compreenderão todos os conceitos técnicos contidos nos laudos de avaliação e no balanço social que serviu de base.

Conforme ASCARELLI, "os problemas mais dificeis quanto à disciplina jurídica dos balanços decorrem justamente da circunstância de ser, ele, inseparável de um juízo técnico na avaliação dos bens sociais"248.

248 ASCARELLI, Tullio. Problemas, op. cit., p. 424. 
Ademais, independentemente do entendimento técnico do conteúdo do laudo pelos acionistas presentes, o auditor independente deverá prestar informações quanto aos critérios utilizados para a avaliação da sociedade a ser incorporada.

As informações prestadas pelo auditor independente na assembleia geral que deliberará sobre o laudo de avaliação, portanto, serão necessárias para a decisão final acerca da operação de incorporação, bem como para a decisão dos minoritários quanto ao exercício do direito de recesso. Ressalte-se, ainda, a importância da prestação de informações aos acionistas considerando que a assembleia geral da sociedade incorporadora não pode arrogar-se a função de perito e alterar o laudo de avaliação, mas tão somente aprová-lo ou rejeitá-lo, hipótese em que a incorporação restará prejudicada.

Finalmente, deve-se questionar o limite dessa prestação de informações pelos auditores, uma vez que estes estão submetidos ao regime de sigilo profissional. Tal questionamento ganha maior relevância se se considerar que, conforme abordado anteriormente, em diversas operações de incorporação o auditor independente contratado para o serviço de asseguração das demonstrações contábeis de uma companhia será o mesmo indicado para a prestação de serviços de avaliação.

Sobre o tema, pode-se argumentar que, considerando ser a assembleia geral restrita aos próprios acionistas da companhia incorporadora e que tais acionistas possuem direito essencial à fiscalização dos negócios sociais, qualquer informação prestada pelos auditores independentes em sede de assembleia geral de incorporação não constituiria uma violação do seu dever de sigilo.

Em pleito diverso, a Terceira Turma do Superior Tribunal de Justiça destacou que quando o conflito é interna corporis, i.e., entre acionistas da mesma sociedade, não há de se alegar o sigilo profissional dos profissionais de auditoria independente para a não divulgação de informações referentes às atividades da companhia. Conforme a ementa do Recurso em Mandado de Segurança nº 28456/SP (2008/0273348-1): 
RECURSO EM MANDADO DE SEGURANÇA. ORDEM JUDICIAL. SEGREDO PROFISSIONAL. INFORMAÇÕES QUE NÃO SE REFEREM A TERCEIROS. INEXISTÊNCIA DE SIGILO.

1- Não se pode recusar o atendimento a ordem judicial com base em suposto segredo profissional, quando os dados tidos por sigilosos envolvem informações adstritas às próprias partes litigantes. No caso, o trabalho de auditoria foi realizado justamente para conhecimento pelos próprios sócios da sociedade empresária da qual o Recorrido se retirou. Portanto, não há que se falar em indevida exposição de segredo profissional perante terceiros, pois a disputa judicial se dá entre sócios e ex-sócios, revelando-se, a controvérsia, conflito interna corporis.

2- Recurso ordinário improvido. ${ }^{249}$

De outro lado, pode-se alegar que o direito à fiscalização dos acionistas não é irrestrito $^{250}$, e que, portanto, é possível ao auditor independente não prestar determinadas informações em sede de assembleia geral de incorporação que aprovará o laudo de avaliação por ele elaborado, sob o argumento de que os diversos acionistas não devem deter todas as informações relevantes das atividades da companhia, as quais serão divulgadas ao mercado somente num momento posterior ${ }^{251}$.

249 STJ RMS 28456/SP, rel. Min. Sidnei Beneti, julgado em 16.08.2011.

250 BULGARELLI, Waldirio. A proteção às minorias na sociedade anônima. São Paulo: Pioneira, 1977 , p.55.

251 Essa, aliás, é a regra nas companhias abertas. 


\section{DA RESPONSABILIDADE CIVIL DOS AUDITORES INDEPENDENTES NAS OPERAÇÕES DE INCORPORAÇÃO}

As atividades desenvolvidas pelos auditores independentes nas operações de incorporação em violação dos seus deveres gerais e específicos, estudados no Capítulo anterior, poderão implicar responsabilização desses agentes em diferentes esferas, seja no âmbito civil, penal ou administrativo. Entre essas, será objeto do presente trabalho o estudo da responsabilidade civil dos auditores independentes relativamente às atividades de auditoria e avaliação desenvolvidas nas hipóteses de incorporações envolvendo companhias abertas.

\subsection{Ordens de responsabilidade civil dos auditores independentes}

As atividades de auditoria e avaliação desenvolvidas pelos auditores independentes nas operações de incorporação, apesar de contratadas pela companhia, podem implicar danos a diferentes pessoas. Isso porque as demonstrações financeiras revisadas e o laudo de avaliação da companhia incorporada servirão como base para a operação de incorporação, impactando (i) no cálculo dos arranjos societários pós-incorporação (fixação do preço de emissão, quantidade de ações a serem detidas pelos acionistas da companhia incorporada no capital social da incorporadora, valor de retirada dos acionistas dissidentes, etc.), (ii) no próprio processo de aprovação da aprovação da operação de incorporação, bem como (iii) na decisão dos investidores relativamente à compra e venda de ações das companhias no mercado de capitais, e (iv) na decisão dos investidores quanto ao fechamento de negócios que dependam de uma reestruturação societária.

Dessa forma, entende-se possível classificar a responsabilidade civil dos auditores independentes em três ordens: (i) responsabilidade perante a companhia; (ii) 
responsabilidade perante os acionistas; e (iii) responsabilidade perante os terceiros (credores e investidores) $^{252}$.

Especificamente em relação aos serviços de auditoria independente prestados (i.e., revisão das demonstrações financeiras das companhias incorporadas que servirão como base para a sua avaliação e para a escrituração contábil da operação de incorporação), há responsabilidade dos auditores independentes não somente perante a companhia incorporada que o contratou, mas também perante terceiros, sobretudo os investidores, conforme o parágrafo $2^{\circ}$ do artigo 26 da Lei $6.385 / 76^{253}$.

Já em relação aos serviços de avaliação do patrimônio líquido da companhia incorporada e, eventualmente, da incorporadora (em se tratando de incorporação de companhia controlada ou sob controle comum), os auditores independentes responderão perante a(s) companhia(s) e também perante os acionistas e terceiros prejudicados (sobretudo credores), conforme o parágrafo $6^{\circ}$ do artigo $8^{\circ}$ da Lei das Sociedades Anônimas ${ }^{254}$.

\subsection{Natureza da responsabilidade civil dos auditores independentes}

252 No direito europeu há similar classificação em relação às ordens de responsabilidade dos auditores independentes. Conforme a EC IP/08/897, item 3.3.1. Disponível em: 〈http://ec.europa.eu/internal_market/auditing/docs/liability/impact_assessment_en.pdf >. Acesso em: 14 out. 2012: "The statutory auditor is liable to his client for damages caused by the auditor's negligence or even willful misconduct. In general, liability actions might be either in contract, tort or both. However, auditors might also be liable to other parties. (...) Individual shareholders, creditors and prospective purchasers of an audited company rely on the statutory auditor's report and may, as a result, suffer damages. In a majority of Member States, any third party could seek to recover damages from the statutory auditor upon proving the elements of the liability claim, usually fault (intentional conduct or negligence in any degree), damage and causation."

253 “As empresas de auditoria contábil ou auditores contábeis independentes responderão, civilmente, pelos prejuízos que causarem a terceiros em virtude de culpa ou dolo no exercício das funções previstas neste artigo".

${ }^{254}$ Da mesma forma, no direito italiano, o artigo 2501 do Codice Civile dispõe que "l'esperto risponde dei danni causati alle società partecipanti alla fusione, ai loro soci e ai terzi. Si applicano le disposizioni dell'art. 64 Cod. Proc. Civ.". 
Em relação à natureza da responsabilidade dos auditores independentes, deve-se definir se há responsabilidade contratual, aquiliana ou mesmo legal ${ }^{255}$. E tal definição deriva naturalmente da própria relação existente entre os auditores independentes, a companhia auditada e os terceiros interessados.

Conforme abordagem do subcapítulo 3.1 supra, a verificação de uma relação jurídica contratual entre os auditores independentes e a companhia, sobretudo pela necessária independência que esses agentes devem ter das companhias auditadas, implicaria invariavelmente uma responsabilidade contratual do auditor em relação à companhia que o contratou, tanto no que diz respeito aos serviços de asseguração como aos serviços de avaliação.

Entretanto, uma vez que aos auditores independentes também se impõem diversos deveres legais, gerais e específicos, pode-se sustentar a existência de uma responsabilidade não contratual desses agentes perante a companhia pelo descumprimento de tais deveres, tanto em relação aos serviços e asseguração como em relação às demais atividades desenvolvidas $^{256}$.

Uma vez que tal responsabilidade não contratual resulta de uma relação especial entre os auditores e as companhias, guiada não somente pelo contrato de prestação de serviços, mas também por diversas normas legais específicas, é possível sustentar a existência de uma responsabilidade legal que extrapola os limites do contrato de prestação de serviços.

255 A responsabilidade contratual é aquela que resulta do descumprimento de obrigações legais definidas, cujo inadimplemento implica uma culpa ex re ipsa. A responsabilidade extracontratual deriva do inadimplemento de uma norma de comportamento que implique dano a alguém. Já a responsabilidade legal é uma modalidade autônoma que deriva da violação de uma regulação legal especial. A respeito, cf. (i) PEREIRA, Caio Mario da Silva. Responsabilidade civil. Rio de Janeiro: Forense, 1989, p. 262 e ss.; e

(ii) GOMES, Orlando. Obrigações. 7. ed. Rio de Janeiro: Forense, 1984, p. 337 e ss.

${ }^{256} \mathrm{Na}$ Europa também se discute a questão da natureza da responsabilidade dos auditores independentes, havendo nos diversos países hipóteses de responsabilidade contratual e extracontratual. A respeito, cf. EC IP/08/897, $\quad$ item 3.3.1. Diponível em: 〈http://ec.europa.eu/internal_market/auditing/docs/liability/impact_assessment_en.pdf $\rangle$. Acesso em: 14 out. 2012. 
No que tange à responsabilidade legal, o mesmo raciocínio aplica-se aos serviços de avaliação prestados pelos auditores independentes nas operações de incorporação em relação aos acionistas e terceiros, sobretudo os credores da companhia avaliada, pois os atos praticados pelos auditores independentes podem implicar prejuízo a esses últimos ${ }^{257}$.

Em classificação diversa, mas ainda sobre a natureza da responsabilidade civil dos auditores independentes, deve-se interpretar o cabimento de responsabilidade subjetiva ou objetiva em vista das atividades desenvolvidas por tais agentes. Assim, argumenta-se que (i) a responsabilidade subjetiva implica incentivos para que os terceiros (investidores e credores) atuem de forma menos negligente em relação à análise das demonstrações financeiras, e que (ii) a responsabilidade subjetiva tende a reduzir as chamadas "lides temerárias" ${ }^{258}$. Ademais, o ordenamento jurídico brasileiro não contém qualquer previsão legal sobre a responsabilidade objetiva dos auditores independentes ${ }^{259}$, fato que reforça a definição da sua natureza como subjetiva.

Interpreta-se, portanto, que a responsabilidade dos auditores independentes possui natureza subjetiva, interpretação esta que tem como fundamentos legais o artigo $26, \S 2^{\circ}$ da Lei 6.385/76, para os serviços de auditoria das demonstrações financeiras, e o artigo 26, $\S 2^{\circ}$ da Lei das Sociedades Anônimas, para os serviços de avaliação de empresas prestados.

257 Conforme EIZIRIK “a responsabilidade do avaliador perante os acionistas e outros eventuais lesados pela avaliação realizada possui natureza tipicamente extracontratual, uma vez que ele é contratado apenas pela companhia ou pelo titular do bem, não havendo nenhuma relação jurídica preexistente com as demais pessoas que podem ser afetadas pelo resultado da avaliação". EIZIRIK, Nelson. A lei das S/A comentada, v. 1. São Paulo: Quartier Latin, 2011, p. 110.

258 A respeito, cf. PEREIRA, Alexandre Demetrius. Auditoria, op. cit., p. 274-275.

259 Ao contrário, o artigo $26, \S 2^{\circ}$ da Lei 6.385/76 dispõe que “as empresas de auditoria contábil ou auditores contábeis independentes responderão, civilmente, pelos prejuízos que causarem a terceiros em virtude de culpa ou dolo no exercício das funções previstas neste artigo"; e que o artigo $8^{\circ}$, §2 $2^{\circ}$ da Lei das Sociedades Anônimas dispõe que "os avaliadores e o subscritor responderão perante a companhia, os acionistas e terceiros, pelos danos que lhes causarem por culpa ou dolo na avaliação dos bens, sem prejuízo da responsabilidade penal em que tenham incorrido; no caso de bens em condomínio, a responsabilidade dos subscritores é solidária". 
Ressalte-se, entretanto, que a prova de culpa ou dolo dos auditores independentes quando da revisão das demonstrações financeiras tende a ser muito difícil pela companhia ou terceiros, razão pela qual há quem sustente que, especificamente na hipótese de prestação de serviços de auditoria, a responsabilidade dos auditores independentes perante terceiros possui natureza subjetiva com presunção iuris tantum de culpa ${ }^{260,261}$.

\subsection{Critérios e pressupostos de definição de responsabilidade}

\subsubsection{Ação ou omissão dos auditores independentes}

O primeiro critério para a existência de responsabilidade dos auditores independentes é a verificação de atos comissivos ou omissivos contrários à lei ou ao respectivo contrato que impliquem dano a outrem. Sem prejuízo, ressalte-se que uma conduta omissiva somente se configura como relevante se houver a violação de um dever de agir ou de não agir imposto aos auditores independentes e, mais do que isso, que tal ação ou inação represente um dano a terceiro ou à companhia, conforme será analisado no subcapítulo seguinte.

Nesse ponto, ressaltamos a importância do estudo dos auditores independentes aplicado à hipótese específica de incorporação entre companhias, tendo em vista que possibilita a análise da legalidade dos seus atos em função de cada atividade exercida por tais agentes.

${ }^{260}$ Cf. PEREIRA, Alexandre Demetrius. Auditoria, op. cit., p. 276 e 278.

261 Adotando a posição de Caio Mario da Silva Pereira, com determinada corrente doutrinária, tal construção nem não seria necessária em relação à responsabilidade do auditor independente perante a companhia se considerarmos a existência de uma relação contratual entre o auditor independente e a companhia. Isso porque a responsabilidade contratual implica naturalmente a inversão do ônus probandi, tornando a posição do lesado mais vantajosa. A respeito, cf. PEREIRA, Caio Mario da Silva. Responsabilidade civil. Rio de Janeiro: Forense, 1989, p. 265. 
Entre os atos comissivos que implicam responsabilidade dos auditores independentes nas hipóteses de incorporação de companhias, o primeiro conjunto de atos a se destacar são os atos praticados contrariamente aos deveres gerais previstos no subcapítulo 4.1 supra, imperativos legais impostos aos auditores em sua atuação geral. A violação de tais deveres gerais pode causar graves danos às companhias e ao mercado, com destaque para a violação do dever de sigilo, o qual, conforme já analisado, possui enorme importância para as companhias, em relação aos seus segredos de comércio, e para o mercado, em relação à assimetria de informações.

Destaca-se, ademais, a violação dos deveres específicos abordados no subcapítulo 4.2 supra, os quais se relacionam especificamente com as atividades de auditoria das demonstrações financeiras e de avaliação de empresas. Em relação à atividade de avaliação de empresas para fins de aferição do valor da companhia a ser incorporada, a responsabilidade dos auditores independentes pode surgir tanto (i) pela escolha do(s) critério(s) inadequado(s) para a referida avaliação, se adotada a corrente favorável à real avaliação, conforme abordagem do subcapítulo 4.2.2.3 supra $^{262}$, como (ii) nos casos de fraude no uso dos referidos critérios de avaliação, destacando-se, neste último caso, a hipótese típica de superestimação do valor de algum ativo constante no balanço da companhia incorporada, quando realizada avaliação sob o critério do valor contábil.

Já em relação à atividade de revisão das demonstrações financeiras, a principal hipótese comissiva de responsabilidade dos auditores independentes é o caso de fraude, cujo conceito relaciona-se aos atos praticados no sentido de frustrar a lei ${ }^{263}$.

${ }^{262}$ Em raciocínio contrário, não haveria responsabilidade dos auditores pela escolha dos critérios de avaliação se adotada corrente segundo a qual o objetivo do avaliador é simplesmente o de verificar se o valor do patrimônio líquido da companhia incorporada é ao menos igual ao valor do capital a realizar por virtude do aumento de capital social consequente da incorporação. A respeito, cf. análise do subcapitulo 4.2.2.3 supra.

263 Conforme voto do Ministro Humberto Gomes de Barros em seu voto como relator no Resp 207484/SP, rel. Min Humberto Gomes de Barros, julgado em 13.06.2000, "com efeito, fraude - todos nós sabemos é o ardil, pelo qual uma sequencia de atos ilícitos conduz a resultado ilícito. Vale dizer, contorna-se o preceito legal sem o agredir diretamente". Maria Helena Diniz define fraude no direito civil como " $a$ ) Manobra artificiosa para prejudicar terceiro; b) má-fé; c) engano ou burla; ocultação da verdade". DINIZ, Maria Helena. Dicionário jurídico, v. 1. 3. ed. rev. e at. São Paulo: Saraiva, 2008. A respeito, cf. ainda A NBC PA 240, aprovada pela Resolução 1.207/09 do CFC, dispõe que "fraude é o ato intencional 
Já em relação aos atos omissivos que implicam responsabilidade dos auditores independentes, novamente há que se analisar a responsabilidade desses agentes em função das atividades de auditoria e avaliação que desenvolvem nas hipóteses de incorporação de companhias.

Nas atividades de avaliação de empresas, verifica-se omissão relevante quando, por exemplo, não há reavaliação de determinado ativo quando de uma análise procedida sob o critério do valor contábil ajustado a preços de mercado, ou quando for desconsiderada alguma variável relevante para a geração de receita pela companhia quando da análise procedida sob algum critério econômico.

Nas atividades de auditoria das demonstrações financeiras, a responsabilidade por omissões culposas e negligências por parte dos auditores independentes deve ser entendida como um incentivo a um maior zelo nas revisões, haja vista que o histórico de escândalos envolvendo demonstrações financeiras de companhias abertas indica que esta é a hipótese de maior incidência de ilegalidades por parte das grandes sociedades de auditoria. Nesses casos, a responsabilidade dos auditores independentes por omissão deve ser apurada cuidadosamente com base em três premissas.

de um ou mais indivíduos da administração, dos responsáveis pela governança, empregados ou terceiros, que envolva dolo para obtenção de vantagem injusta ou ilegal".

Em sentido contrário, entendendo que o dolo não é elemento necessário à configuração da fraude, cf. (i) Min. Eros Roberto Grau, segundo o qual "intencionalidade de violação da lei não é determinante de fraude, de modo que se possa imputar a quem a pratica fecha de fraudador" (STF Rcl 8.025/SP, relator Min. Eros Grau, julgado em 09.12.2009), e (ii) Pontes de Miranda, segundo o qual, "o étimo e o conceito de infração, que alude a frustração, corte, mais traduzem o que se passa com a incidência da regra jurídica de sanção, ainda se indireta a violação da lei. De modo que, se se usa "fraude à lei", tem-se de abstrair a intencionalidade. Não há por onde se procurar o intuitus; basta a infração mesma. Toda investigação do intuito pode levar À confusão da fraude à lei com a simulação.” PONTES DE MIRANDA, Francisco Cavalcanti. Tratado de direito privado, t. 1, at. por Judith Martins Costa [et. al.]. São Paulo: RT, 2012, p. 104. 
Em primeiro lugar, deve-se analisar se os auditores tiveram acesso a todas as evidências de auditoria ${ }^{264,265}$ suficientes para o desenvolvimento dos trabalhos de revisão. Caso contrário, entendemos possível limitar a responsabilidade do auditor independente, e, por consequência a reparação integral do dano sofrido pela companhia, uma vez que o artigo 945 do Código Civil Brasileiro ${ }^{266}$ e a doutrina pátria permitem tal limitação quando há culpa recíproca entre o auditor independente e a companhia ou quando o dano se compõe de vários elementos e sua agravação, nas consequências indiretas, se deve à negligência da vítima (companhia) ${ }^{267}$.

Em segundo lugar, deve-se considerar que o escopo da avaliação dos auditores independentes não é o de verificar todas as inconsistências nas demonstrações financeiras, mas somente apontar as distorções relevantes, resultantes de erro ou fraude, entendendo-se como relevantes as disparidades que possam influenciar de forma significativa na decisão econômica tomada com base nas demonstrações financeiras ${ }^{268}$.

Finalmente, deve-se avaliar se a omissão constituiu violação às regras técnicas de revisão de demonstrações financeiras impostas pelo CFC e pela CVM, que são os preceitos legais técnicos de atuação impostos aos auditores independentes.

264 Conforme o item 13.b da NBC TA 200, “evidências de auditoria-informações usadas pelo auditor para chegar às conclusões em que baseia a sua opinião. As evidências de auditoria incluem informações contidas nos registros contábeis subjacentes às demonstrações contábeis e outras informações. Para fins das NBC TAs: (i) A suficiência das evidências de auditoria é a medida da quantidade da evidência de auditoria. A quantidade necessária da evidência de auditoria é afetada pela avaliação do auditor dos riscos de distorção relevante e também pela qualidade de tal evidência. (ii) A adequação da evidência de auditoria é a medida da qualidade da evidência de auditoria; isto é, sua relevância e confiabilidade no fornecimento de suporte às conclusões em que se baseia a opinião do auditor".

265 As evidências de auditoria são pormenorizadamente reguladas pelo Conselho Federal de Contabilidade nas normas NBT TA 500, NBT TA 501, NBT TA 505 e NBT TA 520.

266 “Art. 945. Se a vítima tiver concorrido culposamente para o evento danoso, a sua indenização será fixada tendo-se em conta a gravidade de sua culpa em confronto com a do autor do dano".

267 A respeito, cf. GOMES, segundo o qual haveria, nesses casos, uma a compensatio lucri cum damno, ou seja, a indenização seria deduzida na proporção da responsabilidade da vítima. GOMES, Orlando. Obrigações. 7. ed. Rio de Janeiro: Forense, 1984, p. 348.

268 Conforme o item 6 da NBC TA 200, “em geral, as distorções, inclusive as omissões, são consideradas relevantes se for razoável esperar que, individual ou conjuntamente, elas influenciem as decisões econômicas dos usuários tomadas com base nas demonstrações contábeis". 


\subsubsection{Dano}

Outro elemento essencial à caracterização da responsabilidade civil dos auditores independentes é a existência de dano por parte dos agentes envolvidos com o seu trabalho. Nesse ponto, deve-se analisar o dano sofrido tendo em vista (i) o agente lesado em virtude da atividade dos auditores independentes, tendo como foco as operações de incorporação, e, obviamente, (ii) as principais atividades desenvolvidas pelos auditores nessas operações, quais sejam, a auditoria das demonstrações financeiras e a avaliação do patrimônio líquido da companhia incorporada.

Em relação a ambas as atividades referidas, a violação dos deveres gerais impostos aos auditores independentes, conforme dispostos no subcapítulo 4.1 supra, implica dano direto à companhia que contratou os auditores independentes, seja pela possível perda de um negócio consequente da quebra do dever de sigilo pelos auditores independentes, ou mesmo quando o mercado precifica negativamente os escândalos que abalem a independência de tais profissionais frente à companhia auditada. Nesses casos, os danos sofridos pelas companhias poderão ser objeto de reparação.

Em relação às atividades de auditoria das demonstrações financeiras, as ações e omissões lesivas dos auditores independentes implicarão naturalmente dano à companhia auditada e aos seus acionistas, pois os investimentos no mercado de capitais, as operações de financiamento e outras atividades comerciais pressupõem análise minuciosa das demonstrações financeiras da companhia auditada.

Analisando especificamente a hipótese de incorporação entre companhias, deve-se considerar que as demonstrações financeiras auditadas servirão como base para a avaliação da companhia incorporada, de forma que as distorções relevantes não verificadas pelos auditores independentes nas demonstrações financeiras impactarão na avaliação da companhia incorporada e, por consequência, no valor final do aumento do capital social da companhia incorporadora, podendo causar danos específicos às companhias envolvidas e aos seus acionistas. 
Questão importante é definir o valor exato do dano sofrido pelas companhias auditadas e pelos seus acionistas, e, portanto, o valor a ser ressarcido pelos auditores. Entendemos que, em se tratando de companhia aberta auditada, o dano sofrido pode ser mensurado considerando-se duas variáveis: (i) a queda no valor de mercado da companhia, seja em relação à companhia incorporada antes, ou à incorporadora sucessora após a incorporação, descontando-se eventuais influências macroeconômicas; e (ii) a real perda de oportunidades negociais pela descoberta de incorreções nas demonstrações financeiras auditadas, sobretudo aquelas que envolvem direta análise das demonstrações financeiras, como a contratação de empréstimo e a emissão de títulos de dívida.

Em relação aos trabalhos de avaliação da companhia a ser incorporada, desenvolvidos pelos auditores independentes no âmbito de uma operação de incorporação, a existência de superavaliação ou de subavaliação determinará os agentes prejudicados, bem como a extensão do dano causado pela má avaliação.

Nesse sentido, a subavaliação implicará danos aos acionistas da companhia incorporada, os quais terão reduzidos os valores de suas participações e receberão menor fração do capital social da companhia incorporadora ao final da operação. Assim, o dano emergente dos acionistas da companhia incorporada será equivalente ao valor da diluição equivocada no capital social da companhia incorporadora, ou, no caso dos acionistas que optarem pelo direito de recesso ${ }^{269}$, será equivalente ao decréscimo no valor de retirada recebido pelas suas ações da companhia incorporada.

Já a superavaliação da companhia incorporada prejudicará os acionistas da companhia incorporadora, que sofrerão dano equivalente à diluição equivocada da sua participação societária ao final do processo de incorporação. Ademais, a superavaliação será prejudicial à companhia incorporadora, por ofensa ao princípio da realidade do capital social que será fixado ao final da incorporação, bem como poderá prejudicar os seus

${ }^{269}$ Conforme artigo 137 combinado com o artigo 136 ou conforme o artigo 264 da Lei das Sociedades por Ações. 
posteriores credores, que tomaram decisões baseadas nos valores constantes no patrimônio líquido da companhia incorporadora.

\subsubsection{Nexo de causalidade}

Outro requisito para a caracterização da responsabilidade civil dos auditores independentes nas hipóteses de incorporação é a prova da causalidade entre a ação ou omissão dos atos praticados por tais agentes e o dano sofrido pela companhia, por seus acionistas ou por terceiros.

Nas hipóteses de violação dos deveres gerais, de erro ou de fraude pelos auditores independentes quando da revisão das demonstrações financeiras e da elaboração dos laudos de avaliação do patrimônio da companhia incorporada (hipóteses comissivas) a verificação do nexo de causalidade é natural, uma vez que os atos praticados por tais agentes podem implicar dano direto à companhia, aos seus acionistas e a terceiros.

Há, entretanto, grande dificuldade em se provar o nexo de causalidade nas hipóteses de omissão do auditor independente, seja por culpa ou por negligência. De um lado, a companhia, os acionistas e os terceiros prejudicados tenderão a afirmar que se basearam no parecer dos auditores independentes sobre as demonstrações financeiras e no laudo de avaliação da companhia incorporada para a análise das condições do processo de incorporação e, portanto, para a tomada de suas decisões.

De outro lado, os auditores independentes sustentarão que tanto o parecer sobre as demonstrações financeiras como o laudo pericial contábil foram elaborados com base nas informações contábeis equivocadamente fornecidas ou escrituradas pela companhia, portanto de responsabilidade dos seus administradores e contadores. 
Há, portanto, uma necessidade de determinação de um critério objetivo para a verificação de um nexo de causalidade entre a conduta omissiva dos auditores independentes e o dano causado. Em relação às atividades de auditoria, propõe-se que o critério objetivo seja a verificação de distorções efetivamente relevantes ${ }^{270}$ (e não quaisquer escriturações errôneas) nas demonstrações financeiras da companhia e não apontadas pelo auditor independente em sua atividade de revisão ${ }^{271}$.

Isso porque, conforme abordagem do subcapítulo 4.2.1.2 acima, o objetivo dos trabalhos de auditoria independente é o de garantir uma segurança razoável às demonstrações financeiras elaboradas pela companhia incorporada, apontando eventuais distorções relevantes resultantes de erros ou fraudes dos agentes responsáveis pela escrituração e dos administradores. Ademais, há que se considerar (i) a racionalidade limitada dos auditores independentes enquanto agentes revisores, consequente da sua limitação cognitiva ${ }^{272}$, bem como (ii) a existência de suficientes evidências de auditoria que possibilitem a plena revisão.

Já em relação às atividades de avaliação da companhia incorporada, propõe-se que o critério objetivo para a existência de responsabilidade civil em hipóteses omissivas dependa do critério de avaliação utilizado. Caso a avaliação seja feita pelo valor contábil, a prova do nexo de causalidade seguirá o mesmo critério das distorções relevantes acima previstas, tendo em vista que a avaliação seguirá puramente as demonstrações contábeis da companhia incorporada.

No caso da avaliação a valor contábil ajustado a preços de mercado, haverá também necessidade de utilização do critério das distorções relevantes, mas nesse caso acrescido da

\footnotetext{
270 Conforme o item 6 da NBC TA 200, “em geral, as distorções, inclusive as omissões, são consideradas relevantes se for razoável esperar que, individual ou conjuntamente, elas influenciem as decisões econômicas dos usuários tomadas com base nas demonstrações contábeis".

${ }^{271}$ No mesmo sentido, cf. PEREIRA, Alexandre Demetrius. Auditoria das demonstrações contábeis, op. cit., p. 278 e ss.

${ }^{272}$ A respeito, confira análise econômica no subcapítulo 4.2.1.2 supra.
} 
necessidade de apuração de negligência em relação aos métodos de reavaliação dos ativos e passivos contabilizados. Essa última hipótese, aliás, é a que naturalmente seria questionada em relação à responsabilidade dos auditores independentes pela avaliação dos patrimônios líquidos das companhias incorporadas e incorporadoras a preços de mercado, devido à exigência do artigo 264 da Lei das Sociedades Anônimas.

Especificamente no caso de responsabilidade dos auditores independentes perante terceiros, tanto em relação às atividades de asseguração, como em relação às de avaliação, há que se discutir até que ponto as atividades daqueles implicam consequente dano às pessoas que não o contrataram. Nesse ponto, o direito norte-americano contém importante construção jurisprudencial.

O primeiro grande julgado sobre o assunto foi o conhecido caso Ultramares Corp. vs. Touche, julgado em 1931 e que deu origem à chamada Ultramares Doctrine. Naquele pleito, decidiu-se que a negligência do auditor independente não ensejaria responsabilidade perante terceiros, uma vez que tal responsabilidade implicaria um risco desproporcional aos contabilistas enquanto auditores, gerando um passivo de montante e prazo indeterminados $^{273}$, razão pela qual os auditores somente poderiam ser responsabilizados em caso de fraude.

A Ultramares Doctrine, entretanto, mostrou-se insuficiente em face do aumento da credibilidade e da utilização dos trabalhos dos auditores independentes por terceiros como base para a tomada de decisões econômicas. Diante de tal cenário, em diversos pleitos as cortes norte-americanas passaram a decidir em favor da responsabilidade dos auditores

273 Conforme o voto do relator do caso, O. J. Cardozo, "if liability for negligence exists, a thoughtless slip or blunder, the failure to detect a theft or forgery beneath the cover of deceptive entries, may expose accountants to a liability in na indeterminate amount for an indeterminate time to an indeterminate class. The hazards of a business conducted on these terms are so extreme as to enkindle doubt whether a flaw may not exist in the implication of a duty that exposes to these consequences". Ultramares Corp. vs. Touche (Newy York, 1931). 
independentes perante terceiros quando estes forem conhecidos ou previsíveis por tais agentes, criando uma nova corrente denominada Foreseeable Doctrine ${ }^{274}$.

Atualmente, os diferentes estados norte-americanos utilizam ambas as correntes alternativamente para embasarem a sua orientação quanto à responsabilidade dos auditores independentes perante terceiros.

Ressalte-se, entretanto, que tais construções jurisprudenciais referem-se à limitação da responsabilidade dos auditores independentes na hipótese de negligência, sendo que na hipótese de fraude tais agentes deverão ser responsabilizados de forma irrestrita ${ }^{275}$.

No direito norte-americano, ademais, especificamente quanto à responsabilidade dos auditores perante terceiros investidores do mercado de capitais, a Section 119(a)(4) é permissiva ao dispor que,

In case any part of the registration statement, when such part became effective, contained an untrue statement of a material fact or omitted to state a material fact required to be stated therein or necessary to make the statements therein not misleading, any person acquiring such security (unless it is proved that at the time of such acquisition he knew of such untruth or omission) may, either at law or in equity, in any court of competent jurisdiction, sue (...) every accountant, engineer, or appraiser, or any person whose profession gives authority to a statement made by him, who has with his consent been named as having prepared or certified any part of the registration statement, or as having prepared or certified any report or valuation which is used in connection with the registration statement, with respect to the statement in such registration statement, report, or valuation, which purports to have been prepared or certified by him.

${ }^{274}$ A respeito, cf. os seguintes julgados: Rosenblum, Inc. vs. Adler (New Jersey, 1983) e Credit Alliance Corp. vs. Arthur Andersen \& Co (New York, 1985).

${ }^{275}$ Conforme voto de O. J. Cardozo no caso Ultramares Corp. vs. Touche (New York, 1931), "to creditors and investors to whom the employer exhibited the certificate, the defendants owed a like duty to make it without fraud, since there was notice in the circumstances of its making that the employer did not intend to keep it to himself. (...) A different question develops when we ask whether they owed a duty to these to make it without negligence". 
Já a Section 10A(c) do posterior Securities and Exchange Act de 1934 impôs expressa limitação à responsabilidade dos auditores independentes, ao dispor que "no registered public accounting firm shall be liable in a private action for any finding, conclusion, or statement expressed in a report made pursuant to paragraph (3) or (4) of subsection (b), including any rule promulgated pursuant thereto".

Quanto ao direito brasileiro, a inexistência de pormenorizada regulação sobre a responsabilidade pelas atividades praticadas pelos auditores independentes e a carência de jurisprudência e doutrina especializadas indicam que o tema deve ser discutido à luz da teoria geral da responsabilidade civil aplicada às especificidades do artigo $26, \S 2^{\circ}$ da Lei 6.385/76 (acerca dos serviços de asseguração) e do artigo $8^{\circ}$, $6^{\circ}$ da Lei 6.404/76 (acerca dos serviços de avaliação).

Nessa esteira, entende-se que há responsabilidade dos auditores independentes perante terceiros prejudicados (credores e investidores) somente quando estes tenham objetiva e comprovadamente tomado as suas decisões econômicas com base nas demonstrações financeiras e no laudo de avaliação produzido pelos auditores independentes (e não nas demonstrações financeiras da companhia auditada). Isso porque o nexo de causalidade que implica responsabilidade aos auditores independentes é aquele que constitui vínculo direto entre a ação do auditor independente e o dano sofrido, conforme princípio da causalidade imediata.

Sobre o conceito, ORLANDO GOMES entende que,

Considera-se vítima, em princípio, a pessoa diretamente prejudicada pelo ato ilícito, conforme o princípio da causalidade imediata. $\mathrm{O}$ direito de reclamar a indenização não nasce para os que sofreram prejuízo indiretamente ou de modo reflexo. Aqueles a quem o ato ilícito prejudica por esses modos não se investem, pois, na pretensão de indenização. ${ }^{276}$

276 GOMES, Orlando. Obrigações, op. cit., p. 345. 


\subsubsection{Responsabilidade individual e solidária}

Nas operações de incorporação entre companhias, a responsabilidade dos auditores independentes pela atividade de avaliação da companhia incorporada é solidária à responsabilidade do subscritor em relação à companhia, aos acionistas e terceiros prejudicados, nos termos do artigo $8^{\circ}, \S 6^{\circ}$ da Lei das Sociedades Anônimas.

Nesse ponto, destacamos que, conquanto os acionistas da companhia incorporada e até os seus diretores envolvem-se diretamente na negociação e nos termos da operação de incorporação, o conceito de subscritor trazido pelo referido dispositivo da Lei das Sociedades Anônimas refere-se aos acionistas da companhia incorporada que subscreverão quotas do capital social da incorporadora. Dessa forma, apenas conjuntamente com os acionistas da companhia incorporada a lei prevê a responsabilidade solidária dos auditores independentes.

Em relação aos serviços de asseguração, entendemos que o artigo 942 do Código Civil Brasileiro prevê que a responsabilidade dos auditores independentes deve ser solidária à dos administradores e agentes responsáveis pela escrituração das demonstrações financeiras, sob o fundamento da regra geral de responsabilidade civil solidária disposta no artigo $942^{277}$ do Código Civil Brasileiro. Tal regra, ademais, não é contrariada pela regra especial de responsabilidade do auditor prevista no artigo $26, \S 2^{\circ}$ da Lei. 6.385/76, segundo o qual "as empresas de auditoria contábil ou auditores contábeis independentes responderão, civilmente, pelos prejuízos que causarem a terceiros em virtude de culpa ou dolo no exercício das funções previstas neste artigo" ${ }^{278}$.

277 “Art. 942. Os bens do responsável pela ofensa ou violação do direito de outrem ficam sujeitos à reparação do dano causado; e, se a ofensa tiver mais de um autor, todos responderão solidariamente pela reparação."

${ }^{278}$ A responsabilidade solidária dos auditores independentes é também a regra na maioria dos países da Europa. Conforme a EC IP/08/897, item 3.3.1. Disponível em: 〈http://ec.europa.eu/internal_market/auditing/docs/liability/impact_assessment_en.pdf $\rangle$. Acesso em: 14 out. 2012: "The liability of the auditor and the audited company towards third parties (shareholders, creditors) and of the advisors of the company (auditors and other advisors) towards the company is joint and several in almost all Member States (see Annex 4). Under the system of joint and several liability, the auditors might be held financially liable "in solidum" with other parties, towards the victim for the whole 
Finalmente, há que se destacar a existência, no direito brasileiro, de responsabilidade civil solidária e ilimitada dos sócios das sociedades de auditoria perante a própria sociedade. Isso porque o inciso III do artigo $4^{\circ}$ da Instrução Normativa CVM 308/99 dispõe que as sociedades de auditoria independente devem

Constar do contrato social, ou ato constitutivo equivalente, cláusula dispondo que a sociedade responsabilizar-se-á pela reparação de dano que causar a terceiros, por culpa ou dolo, no exercício da atividade profissional e que os sócios responderão solidaria e ilimitadamente pelas obrigações sociais, depois de esgotados os bens da sociedade. (grifo nosso)

\subsection{Limitações à responsabilidade dos auditores independentes}

Questão importante sobre a responsabilidade civil dos auditores independentes é a ponderação sobre a necessidade de se desestimular os comportamentos ilegais por parte desses agentes com a necessidade de se limitar as hipóteses de reparação deles exigida, sob pena de se aumentar o risco inerente às atividades de auditoria e avaliação a um nível que torne as atividades dos auditores impraticáveis ${ }^{279}$.

Em outras palavras, a análise da aplicabilidade dos critérios acima mencionados cumpre não somente a função de indenizar a companhia, os seus acionistas ou terceiros prejudicados, mas também desestimular comportamentos prejudiciais pelos auditores

damage. In the case of a failed company, therefore, third parties may decide to sue the directors of the company (who carry legal responsibility for the financial statements of the company). They may also sue the statutory auditors, who have provided an unqualified audit report for the company prior to its collapse, even if the auditor's fault and contribution to the damage is of minor importance."

279 Tal discussão, na verdade, está inserida dentro do contexto moderno de utilização da responsabilidade civil como um mosaico de demandas sociais, constatando-se a sua utilidade não somente para a reparação da vítima, como também à prevenção de condutas ilícitas. A respeito, cf. LEVY, Daniel de Andrade. Responsabilidade civil: de um direito dos danos a um direito das condutas lesivas. São Paulo: Atlas, 2012. 
independentes $^{280}$. Entretanto, deve-se ponderar tal política de desestímulo a comportamentos indesejados em função dos riscos envolvidos na responsabilização desmedida dos auditores independentes.

No Direito Europeu há importantes discussões sobre a limitação da responsabilidade dos auditores independentes face ao decréscimo do número de grandes firmas de auditoria após o surgimento de graves escândalos contábeis envolvendo companhias abertas. Constatou-se que a responsabilização civil dos auditores independentes, somada (i) à consequente ausência de coberturas de seguros oferecidas a esses profissionais como consequência do número excessivo de condenações e (ii) ao número reduzido de grandes empresas de auditoria implicaria um risco de extinção desses profissionais ou uma limitação indesejada da sua atividade no mercado de capitais $^{281,282}$,

Sobre o assunto um importante estudo foi realizado pelas universidades London Economics e Goethe University ${ }^{283}$, cujas conclusões foram as seguintes:

${ }^{280}$ A análise econômica do direito sugere que a responsabilização e a consequente indenização faz com que o autor do dano internalize os custos e benefícios marginais da precaução, dando-lhe incentivos para tomar precauções eficientes. A respeito, cf. COOTER, Robert; ULEN, Thomas. Direito \& Economia. Trad. SANDER, Francisco Araújo da Costa. 5. ed. Porto Alegre: Bookman, 2010.

281 Conforme palavras do Secretário da Comissão de Mercado Interno e Serviços da União Europeia, Charlie McCreevy, em discurso proferido em 2006: "After in-depth research and extensive consultation, we have concluded that unlimited liability combined with insufficient insurance cover is no longer tenable. It is a potentially huge problem for our capital markets and for auditors working on an international scale. The current conditions are not only preventing the entry of new players in the international audit market, but are also threatening existing firms. In a context of high concentration and limited choice of audit firms, this situation could lead to damaging consequences for European capital markets".

282 Conforme Klaus Hopt, “de fato, após o desaparecimento da Arthur Andersen, há um fechado oligopólio dos quatro maiores operadores do mercado de auditoria. A satisfação dos requisitos de independência é hoje muito difícil e perder outra empresa de auditoria, como consequência da imputação de responsabilidade, seria um pesadelo concorrencial'. HOPT, Klaus. Direito societário, governo corporativo e a disciplina jurídica das ofertas públicas de aquisição na União Europeia: balanço, problemas com as reformas e perspectivas in WARDE JR., Walfrido Jorge (org.). Fusão, cisão, incorporação e temas correlatos. São Paulo: Quartier Latin, 2009, p. 356.

${ }^{283}$ Cf. versão integral do estudo disponível em: 〈http://ec.europa.eu/internal_market/auditing/docs/liability/auditors-final-report_en.pdf >. Acesso em: 14 out. 2012. 
1) The international market for statutory audits of large and very large companies is highly concentrated and dominated by the Big-4 networks. The likelihood of new entrants into this market is very limited in the coming years. Additionally, under the current circumstances, middle-tier firms are unlikely to become a major alternative if a Big-4 network fails.

2) The level of auditor liability insurance available for higher limits has fallen sharply in recent years. The remaining source of funds to face claims may essentially be the income of partners belonging to the same international network. Constantly large claims might therefore put at risk an entire network.

3) The failure of a network could lead to difficult consequences for the wider economy like a significant reduction in large company statutory audit capacity possibly creating serious problems for companies whose financial statements need to be audited.

4) A limitation on auditor liability would reduce this risk. While there exist a number of variants of statutory audit liability limitation, the diversity of circumstances in terms of both audits and company size is such that it is unlikely that a one-size-fits-all EU-wide approach is the most useful.

Após analisar tal estudo e realizar diversas consultas públicas, a Comissão responsável da União Europeia publicou uma recomendação oficial (EC IP/08/897 284 ) aos países membros no sentido de limitarem a responsabilidade civil dos auditores independentes. Com tal recomendação, optou-se por deixar a cargo de cada EstadoMembro decidir pela forma de limitação da responsabilidade dos auditores independentes, mas foi proposta uma série de princípios no sentido de garantir limitações razoáveis de acordo com os interesses dos auditores, das companhias auditadas, dos investidores e dos credores.

No direito norte-americano, as construções doutrinárias e jurisprudenciais sobre a limitação da responsabilidade dos auditores independentes perante terceiros estão consubstanciadas nas correntes da Ultramares Doctrine e da Foreseeeable Doctrine, bem como na Section 10A(c) do posterior Securities and Exchange Act de 1934, conforme estudados no subcapítulo 5.3.3 supra.

${ }^{284}$ Disponível em:〈http://ec.europa.eu/internal_market/auditing/docs/liability/impact_assessment_en.pdf〉. Acesso em: 14 out. 2012. 
No direito brasileiro, não existem grandes discussões específicas sobre a necessidade de limitação da responsabilidade dos auditores independentes, a despeito da grande importância econômica das atividades prestadas por tais agentes. Tal constatação é possivelmente consequência do reduzido número de pleitos sobre a responsabilização dos auditores independentes, a despeito dos inúmeros escândalos contábeis de companhias $\operatorname{auditadas}^{285}$.

Sem prejuízo, apesar de no Brasil ainda não haver discussões sobre a limitação da responsabilidade dos auditores independentes como política pública necessária à continuidade das atividades praticadas por tais agentes, entendemos relevante definir institutos jurídicos para que tal limitação seja realizada casuisticamente.

O primeiro instituto jurídico que permite limitar a responsabilidade civil dos auditores independentes, já abordado, é a definição da natureza da responsabilidade desses agentes como subjetiva com presunção iuris tantum de culpa em relação às atividades de asseguração.

O segundo instituto a servir como limitador da responsabilidade dos auditores independentes, também já abordado, é a compensação da indenização com a culpa recíproca, i.e., a fixação de uma responsabilidade dos auditores proporcional ao dano causado em concurso com a companhia, os agentes responsáveis pela escrituração contábil e os administradores. Tal responsabilidade proporcional (proportionate liability), conjuntamente com a responsabilidade limitada a um determinado valor (cap liability), são as formas mais utilizadas pelos países da Europa para a limitação da responsabilidade dos auditores independentes ${ }^{286,287}$.

285 Nossa pesquisa em jurisprudência e doutrina pátrias apresentou raras discussões sobre a responsabilidade dos auditores independentes pelas atividades por eles praticadas, não obstante a ocorrência de diversos casos de fraudes contábeis de companhias abertas auditadas, de grande relevância para o mercado de capitais e o sistema financeiro nacional.

286 Conforme a EC IP/08/897, item 5.2.3.3. Disponível em: 〈http://ec.europa.eu/internal_market/auditing/docs/liability/impact_assessment_en.pdf〉. Acesso em: 14 out. 2012. 
Outra forma anteriormente abordada de limitação da responsabilidade dos auditores independentes é a definição de critérios objetivos para o reconhecimento do nexo de causalidade entre as ações ou omissões desses agentes, tanto em relação às atividades de asseguração como em relação às de avaliação, com o dano sofrido pela companhia, pelos acionistas e por terceiros. Conforme abordagem do subcapítulo 5.3 anterior, tais critérios objetivos relacionam-se com o escopo principal de cada atividade desenvolvida, e servirão para que os auditores independentes não sejam responsabilizados por falhas inevitáveis mesmo quando os trabalhos centrais são corretamente realizados.

Finalmente, o instituto da prescrição funciona como limitador à responsabilidade dos auditores independentes. Em relação à pretensão dos acionistas, da companhia e dos terceiros interessados em exigir reparação dos auditores independentes pelas atividades de avaliação da companhia incorporada, o inciso I do artigo 287 da Lei das Sociedades Anônimas prevê prescrição legal de um ano a contar da data da publicação da ata de assembleia geral que aprovar a conferência dos bens, ou seja, da ata de assembleia geral da companhia incorporadora que aprovar a incorporação ${ }^{288}{ }^{289}$. Ressalte-se, entretanto, que a Lei das Sociedades Anônimas, em seu artigo 288, prevê que quando a ação se originar de fato que deva ser apurado no juízo criminal, não ocorrerá a prescrição antes da respectiva sentença definitiva ou da prescrição da ação penal.

Já em relação à pretensão da companhia, dos acionistas e dos credores pela reparação dos danos sofridos pelos serviços de revisão das demonstrações financeiras da

287 Apesar de ser alternativa interessante e usual dentre diversos países, a utilização no Brasil da responsabilidade civil limitada a um valor determinado (cap liabilty) dependeria de esforços legislativos, pois atualmente o nosso sistema jurídico carece de base legal que suporte tal limitação.

288 Ao fazer referência à reparação em subscrições de capital em geral, entende-se que a norma contida o referido artigo inclui a hipótese específica de incorporação entre companhias. A respeito, cf. GUERREIRO, José Alexandre Tavares; TEIXEIRA, Egberto Lacerda. Das sociedades, op. cit., v. 2, p. 822.

289 Há idêntica previsão no artigo 206, §1º IV do Código Civil Brasileiro. 
companhia incorporada, a prescrição será de três anos, de acordo com a regra geral contida no artigo 206, $\S 3^{\circ}$, V do Código Civil Brasileiro.

\subsection{Ação de responsabilidade}

Finalmente, analisa-se a ação de responsabilidade a ser proposta pela pessoa prejudicada em função das atividades exercidas pelos auditores independentes.

Nesse ponto, novamente será necessária a distinção entre as referidas atividades, devido ao tratamento legal diverso entre ambas. Em relação às atividades de avaliação da companhia incorporada, o próprio artigo $8^{\circ}, \S 6^{\circ}$ da Lei das Sociedades Anônimas garante legitimidade ativa da companhia incorporadora, dos acionistas e dos terceiros em relação à pelos danos causados. Trata-se, pois, de importante novidade da Lei das Sociedades Anônimas em relação ao regime do Decreto-Lei 2.627/40, o qual, em seu artigo $5^{\circ}, \S 5^{\circ}$, previa expressamente responsabilidade dos peritos avaliadores apenas perante a companhia que tivesse o seu capital social aumentado ${ }^{290}$.

Já em relação às atividades de avaliação, o artigo 26, §2 da Lei 6.385/76 garante legitimidade ativa aos terceiros interessados para a propositura de ação civil para a reparação dos danos sofridos, sem, entretanto, fazer referência à companhia auditada. Obviamente, a ausência de referência no referido dispositivo não significa que a companhia não possui legitimidade passiva para pleitear reparação dos danos sofridos, o que poderá ser feito de acordo com regras gerais de responsabilidade civil, ou mesmo pela simples execução do contrato de prestação de serviços. Note-se, entretanto, que o fato de existir um contrato entre a companhia e os auditores independentes, pode implicar, num momento inicial, ausência de interesse de agir por parte da companhia em eventual ação civil de reparação, pois eventuais soluções distintas previstas no contrato para fins de

\footnotetext{
${ }^{290}$ Cf. VALVERDE, Trajano de Miranda. Sociedades, op. cit., v. 3, p. 119.
} 
indenização poderão, nesse momento, retirar o caráter de necessidade e a adequação da referida ação ${ }^{291}$.

Ademais, em se tratando de incorporação entre companhias abertas, ressalte-se a possibilidade de proposição de ação civil pública pelo Ministério Público face aos auditores independentes em relação a ambas as atividades desenvolvidas no âmbito de incorporação entre as companhias. Tal possibilidade é garantida pelo artigo 129, III ${ }^{292}$ da Constituição Federal e pelo artigo $5^{\circ}$, I combinado com o artigo $1^{\circ}$ da Lei 7.347/85, e é aplicável ao presente caso pela necessidade de tutela do interesse coletivo dos investidores do mercado de capitais ${ }^{293}$.

291 A respeito, cf. CINTRA, Antonio Carlos de Araújo; GRINOVER, Ada Pellegrini; DINAMARCO, Cândido Rangel. Teoria geral do processo. 21. ed. São Paulo: Malheiros, 2005, p. 266-267.

292 Art. 129. São funções institucionais do Ministério Público: [...] III - promover o inquérito civil e a ação civil pública, para a proteção do patrimônio público e social, do meio ambiente e de outros interesses difusos e coletivos.

293 Especificamente em relação à atividade de avaliação dos bens a serem conferidos ao capital social (no presente caso, da companhia incorporada), CARVALHOSA leciona que "são legitimados a propor a ação de que trata o presente inciso a companhia, os demais acionistas e subscritores, os credores, os terceiros em geral, e o Ministério Público, quando se tratar de interesse coletivo ou público envolvido (CF de 1988)" (grifo nosso). CARVALHOSA, Modesto. Comentários, op. cit., v. 4, t. 2, p. 286-287. 


\section{CONCLUSÕES}

No presente trabalho, procurou-se estudar os deveres e a responsabilidade civil dos auditores independentes em relação às atividades desenvolvidas por tais agentes no contexto de uma operação de incorporação entre companhias abertas, tendo em vista (i) a relevância das operações de incorporação como ferramenta de reestruturação societária, e (ii) as diferentes atividades desenvolvidas pelos auditores independentes nas operações dessa natureza, sobretudo em vista do artigo 12 da Instrução Normativa CVM no 319/1999 e da reconhecida especialidade desses agentes em relação a tais atividades.

O estudo do ordenamento jurídico brasileiro e de casos práticos de incorporação envolvendo companhias abertas demonstrou que o papel desenvolvido pelos auditores independentes possui grande relevância no contexto dessas operações, impactando de forma relevante no mercado de capitais. Demonstrou-se que a relevância do papel desempenhado pelos auditores independentes é justificada pela sua credibilidade como certificador de informações disponibilizadas e pela prestação de um sem número de serviços além daquele que constitui a atividade precípua de tais agentes, que é a auditoria das demonstrações financeiras.

Como forma de analisar a legalidade e os efeitos da concentração de tais serviços num só agente, estudou-se (i) o regime jurídico das incorporações entre companhias; (ii) o escopo, o âmbito de atuação e a função das atividades dos auditores independentes; (iii) os deveres gerais e específicos desses tais agentes em vista das atividades de auditoria e avaliação desenvolvidas no contexto de uma incorporação; e (iv) a responsabilidade civil dos auditores independentes relativamente às referidas atividades.

Demonstrou-se que o atual regime jurídico das incorporações envolvendo companhias abertas impõe grande importância aos trabalhos desenvolvidos pelos auditores independentes, sobretudo nas operações de incorporação de companhia controlada ou sob controle comum, hipóteses em que se exige a elaboração de um laudo de avaliação dos patrimônios líquidos das companhias incorporadora e incorporada a preços de mercado ou de acordo com outro critério aceito pela CVM. 
Ademais, constatou-se que os deveres legais, gerais e específicos, impostos aos auditores independentes e a relevância das atividades por eles praticadas sugerem a existência de uma relação jurídica que excede os limites dos respectivos contratos de prestação de serviços, fato relevante para a posterior definição da natureza jurídica da responsabilidade civil dos auditores independentes.

Através de um esforço interpretativo das normas internacionais e nacionais, foram definidos os deveres gerais impostos aos auditores independentes, concluindo-se que a concentração das atividades atualmente praticadas pelos auditores independentes no contexto de uma incorporação pode constituir violação, mesmo que potencial, de tais deveres, sobretudo dos deveres de objetividade e independência.

Em relação aos deveres específicos impostos aos auditores independentes, nota-se que as atividades de auditoria das demonstrações financeiras estão pormenorizadamente reguladas pelo ordenamento jurídico nacional, através de leis e normas expedidas por órgãos reguladores e autorreguladores. $\mathrm{O}$ estudo de tais normas revelou que o papel dos auditores independentes enquanto revisores é o de garantir segurança razoável às demonstrações financeiras, através da identificação de distorções relevantes (e não a investigação de fraudes contábeis), devendo-se observar a existência de suficientes evidências de auditoria e as naturais limitações cognitivas inerentes aos auditores independentes.

Não obstante, entende-se ainda necessário regular pormenorizadamente as demais atividades prestadas pelos auditores independentes no âmbito do mercado de capitais, como forma de evitar que comprometam a independência que se exige de tais agentes. Nesse ponto, o presente trabalho se propôs a contribuir com o estudo da regulação das atividades de avaliação de empresas, em vista de o escopo limitar-se às operações de incorporação entre companhias abertas.

Foram definidos os conceitos gerais, as normas aplicáveis, os objetivos e os interesses tutelados na avaliação da companhia incorporada, bem como foram discutidas as peculiaridades dos trabalhos de avaliação desenvolvidos pelos auditores independentes, 
considerando-se cada um dos possíveis critérios de avaliação e as características do laudo de avaliação da companhia incorporada.

Quanto à responsabilidade dos auditores independentes em relação às atividades praticadas no contexto de uma incorporação, demonstrou-se haver diferentes ordens de responsabilidade em função da pessoa prejudicada, bem como foi definida a natureza da responsabilidade civil dos auditores independentes como legal e subjetiva, sendo que, especificamente em relação aos serviços de auditoria das demonstrações financeiras, admitiu-se a possibilidade de presunção iuris tantum de culpa.

Ao discutir-se as ações e omissões dos auditores independentes, o dano sofrido pela companhia, pelos acionistas e pelos demais agentes do mercado, bem como o nexo de causalidade entre as ações e omissões e o dano sofrido, concluiu-se pela necessidade de definição de critérios objetivos que possibilitem a responsabilização dos auditores independentes no âmbito civil. Em relação às atividades de revisão de demonstrações financeiras da companhia incorporada, foi proposto que a responsabilização dos auditores independentes pressuponha a não identificação das distorções relevantes e, em relação às atividades de avaliação da companhia incorporada e da incorporadora, que o critério dependa do método de avaliação utilizado.

Ademais, estudou-se os sistemas legais estrangeiros que podem contribuir para o tema da responsabilidade civil dos auditores independentes no direito brasileiro e demonstrou-se haver atualmente em nosso ordenamento jurídico determinados institutos capazes de limitar tal responsabilidade, como a responsabilidade subjetiva; a compensação por culpa recíproca (incluindo a discussão sobre responsabilidade proporcional e limitada a um valor); a definição de critérios objetivos para a existência de nexo de causalidade entre a ação e omissão do auditor independente e o dano sofrido por terceiros; e a prescrição à pretensão punitiva contra os auditores independentes.

Assim como em relação às demais matérias relativas aos auditores independentes, nossa pesquisa revelou raro material jurídico nacional que discuta a limitação da responsabilidade de tais agentes, tema de elevada importância no contexto de regulação de mercado. Trata-se de moderna discussão no âmbito da União Europeia e dos Estados 
Unidos, cujos juristas preocupam-se com o fato de que de que a responsabilização desmedida dos auditores independentes pode implicar risco de que as atividades desenvolvidas por tais agentes tornem-se impraticáveis, pelo elevado risco de responsabilização profissional e pela abolição dos seguros que cubram tais riscos.

Ao final, entendemos essencial que sejam realizados demais estudos e discussões sobre os deveres e as responsabilidades dos auditores independentes, pois a realidade atual demonstra escasso material doutrinário e jurisprudencial em âmbito nacional. Nesse contexto, espera-se que o presente trabalho sirva como uma contribuição ao estudo do referido tema. 


\section{REFERÊNCIAS BIBLIOGRAFICAS}

ADAMEK, Marcelo Vieira Von. Responsabilidade civil dos administradores de S/A e ações correlatas. São Paulo: Saraiva, 2009.

(coord.). Temas de direito societário e empresarial contemporâneos. São Paulo: Malheiros, 2011.

AICPA - American Institute of Certified Public Accountants. Statement of Position Regarding Mandatory Rotation of Audit Firms of Publicly Held Companies. New York: AICPA, 1992.

AKERLOFF, G. The Market for Lemons: Quality Uncertainty and the Market Mechanism. Quarterly Journal of Economics. v. LXXXIV, n. 3, ago. 1970.

ALMEIDA, Bruno José Machado de; COLIMINA, Clara Isabel Muñoz. Evidencia de las diferencias de expectativas en auditoria en mercados bursátiles de la reducida dimensión: el caso Portugués. Revista Contabilidade \& Finanças, São Paulo, v. XIX, n.47, mai./ago. 2008.

ARAGÃO, Leandro Santos de; CASTRO, Rodrigo R. Monteiro de (org.). Direito societário - desafios atuais. São Paulo: Quartier Latin, 2008.

; ___ (org.). Reorganização societária. São Paulo: Quartier Latin, 2005.

ARRUÑADA, Benito; PAZ-ARES, CÂNDIDO. Mandatory Rotation of Company Auditors: A Critical Examination. International Review of Law and Economics, 1997, v. XVII. em: <http://www.arrunada.org/files/research/ARRUNADA_PAZ_ARES_1997_Mandatory_Ro tation_Aud_IRLE.pdf>. Acesso em: 5 jan. 2012. 
ASCARELLI, Tullio. Problemas das sociedades anônimas e direito comparado. 2. ed. São Paulo: Saraiva, 1969.

ARAGÃO, Paulo Cezar; LIMA, Monique M. Mavignier de. Incorporação de controlada: a disciplina do art. 264 da lei 6.404/1976, in: PERIN JUNIOR, Ecio. Direito empresarial: aspectos atuais de direito empresarial brasileiro e comparado. São Paulo: Método, 2005, p. 345 .

AZEVEDO, Antonio Junqueira de. Negócio jurídico: existência, validade e eficácia. 4. ed. at. São Paulo: Saraiva, 2002.

BAINBRIDGE, Stephen. Mergers and acquisitions. New York: Foundation Press, 2009.

BIMBATO, José Mario. O preço de emissão das ações em aumento de capital. Revista de Direito Mercantil, Industrial Econômico e Financeiro, ano XXXIII, n. 93, p. 81-94, São Paulo: RT, jan./mar. 1994.

BITTAR, Carlos Alberto. Responsabilidade civil: teoria e prática. 3. ed. Rio de Janeiro: Forense, 1999.

BERLE, Adolf A.; MEANS, Gardiner C. A moderna sociedade anônima e a propriedade privada (tradução de The modern corporation and private property). São Paulo: Abril, 1984.

BORBA, José Edwaldo Tavares. Direito societário. Rio de Janeiro: Freitas Bastos, 1995.

BULGARELLI, Waldirio. A proteção às minorias na sociedade anônima. São Paulo: Pioneira, 1977.

A fusão, incorporação e cisão de Sociedades Anônimas, na Lei Nova das Sociedades por Ações. Revista de Direito Mercantil Industrial, Econômico e Financeiro, ano XV, n. 23, p. 39-52. São Paulo: RT, 1976. 
A incorporação das Sociedades Anônimas. São Paulo: Universitária de Direito, 1975.

. Fusões, incorporações e cisões de sociedades. 2.ed. São Paulo: Atlas, 1996.

O direito de recesso nas hipóteses de incorporação, fusão, cisão e participação em grupos de sociedades. exclusão acarretada pela Lei 7.958 de 20.12.89. Revista de Direito Mercantil Industrial, Econômico e Financeiro, ano XXXII, n. 95, p. 71-79. São Paulo: Malheiros, jul./set. 1994.

O direito dos grupos e a concentração de empresas. São Paulo: Universitária de Direito, 1975.

Regime jurídico da proteção às minorias nas S/A, v.1. Rio de Janeiro: Renovar, 2008.

Responsabilidade dos administradores das companhias, in CAHALI, Yussef Said. Responsabilidade civil: doutrina e jurisprudência. São Paulo: Saraiva, 1984, p. 407 e ss.

CAÑIZARES, Felipe de Solá. Tratado del derecho de las sociedades - II. Buenos Aires : Uteha, 1960.

CARNEY, William J. Mergers and acquisitions: cases and materials. New York: Foundation Press, 2000.

CARVALHO DE MENDONÇA, José Xavier. Tratado de direito comercial brasileiro, v. 3. 4. ed. Rio de Janeiro/São Paulo: Freitas Bastos, $1946 .$.

. Tratado de direito comercial brasileiro, v. 4. 4. ed. Rio de Janeiro/São Paulo: Freitas Bastos, 1946. 
CARVAlHOSA, Modesto. Comentários à lei das sociedades anônimas, v. 1. 5. ed. rev. e at. São Paulo: Saraiva, 2007.

Comentários à lei das sociedades anônimas, v. 2. 5. ed. rev. e at. São Paulo: Saraiva, 2007.

. Comentários à lei das sociedades anônimas, v 3. 4. ed. rev. e at. São Paulo: Saraiva, 2009.

. Comentários à lei das sociedades anônimas, v. 4, t. 1. 4. ed. rev. e at. São Paulo: Saraiva, 2009.

Comentários à lei das sociedades anônimas, v .4, t. 2. 3. ed. rev. e at. São Paulo: Saraiva, 2009.

- Responsabilidade civil dos administradores das companhias abertas. Revista de Direito Mercantil, Industrial Econômico e Financeiro, ano XXII, n. 49, p. 14-20, São Paulo: RT, jan/mar. 1983.

; EIZIRIK, Nelson. A nova lei das S.A. São Paulo: Saraiva, 2002.

CASTRO, Rodrigo R. Monteiro; ARAGÃO, Leandro Santos de (coord.). Reorganização societária. São Paulo: Quartier Latin, 2005.

CASTRO, Rodrigo R. Monteiro; AZEVEDO, Luis André N. de Moura (coord.). Poder de controle e outros temas de direito societário e Mercado de Capitais. São Paulo:

Quartier Latin, 2011.

CINTRA, Antonio Carlos de Araújo; GRINOVER, Ada Pellegrini; DINAMARCO, Cândido Rangel. Teoria geral do processo. 21. ed. São Paulo: Malheiros, 2005.

CLARK, Robert Charles. Corporate law. Boston: Aspen, 1986. 
COMISSÃO EUROPEIA: Commission Recomendation of 16 May, 2002 - Statutory Auditors' Independence in the EU: A Set of Fundamental Principles. Disponível em: $<$ http://eurlex.europa.eu/LexUriServ/LexUriServ.do?uri=OJ:L:2002:191:0022:0057:EN:PDF>. Acesso em: 5 jan. 2012.

COMPARATO, Fábio Konder. A Fixação do preço de emissão das ações no aumento de capital da sociedade anônima. Revista de Direito Mercantil, Industrial Econômico e Financeiro, ano XXX, n.81, p. 79-86. São Paulo: RT, jan/mar. 1991.

Direito empresarial: estudos e pareceres. São Paulo: Saraiva, 1995.

Ensaios e pareceres de direito empresarial. Rio de Janeiro: Forense, 1978.

. Incorporação de companhia aberta, subseqüente à aquisição de seu controle acionário por operação registrada em Bolsa de Valores - Exceção a regime especial do art. 264 da Lei de Sociedades por Ações - Ilegitimidade dos acionistas da incorporada para pleitear judicialmente a anulação da assembleia da incorporadora, in Novos ensaios e pareceres de direito empresarial. Rio de Janeiro: Forense, 1981, p. 204.

. Novos ensaios e pareceres de direito empresarial. Rio de Janeiro: Forense, 1981.

. O novo direito de retirada do acionista nos casos de fusão e incorporação. Revista de Direito Mercantil Industrial, Econômico e Financeiro, ano XXXVIII, n. 116, p. 10-16, São Paulo: Malheiros, 1999.

; SALOMÃO FILHO, Calixto. O poder de controle na sociedade anônima. 4. ed. Rio de Janeiro: Forense, 2005.

COOTER, Robert; ULEN, Thomas. Direito \& Economia, trad. SANDER, Francisco Araújo da Costa, 5. ed. Porto Alegre: Bookman, 2010.

COSTA, Philomeno J. Anotações às companhias, v. 1. São Paulo: RT, 1980. 
DAMODARAN, Aswath. Avaliação de investimentos: ferramentas e técnicas para a determinação do valor de qualquer ativo. Trad. Kleber Nunes, versão Eduardo Fortuna e José Rabello de Moraes. 2. ed. Rio de Janeiro: Qualitymark, 2009.

DE PLÁCIDO E SILVA. Vocabulário jurídico. 16. ed. rev. e at. Rio de Janeiro: Forense, 1999.

DINIZ, Maria Helena. Dicionário jurídico, v. 1. 3. ed. rev. e at. São Paulo: Saraiva, 2008.

EASTERBROOK, Frank; FISCHEL, Daniel. The economic structure of corporate law: trading on inside information. Cambridge: Harvard University Press, 1996.

EISENBERG, Melvin Aron. Corporations and other business organizations: statutes, rules, materials, and forms. New York: Foundation Press, 2006.

The structure of the corporation. Washinton: Beard Books, 2006.

EIZIRIK, Nelson. Auditor independente - sigilo profissional. Revista de Direito Mercantil Industrial, Econômico e Financeiro, ano XXXVI, n. 112, p. 136-147. São Paulo: Malheiros, 1998.

. A lei das S/A comentada, v. 1. São Paulo: Quartier Latin, 2011.

. Aspectos modernos do direito societário. Rio de Janeiro: Renovar, 1992.

- Insider Trading e Responsabilidade de Administrador de Companhia Aberta. Revista de Direito Mercantil, Industrial, Econômico e Financeiro, ano XXII, n. 50, p. 4256. São Paulo: RT, abr./jun. 1983.

. Poder de polícia da CVM frente aos auditores independentes. Revista de Direito Administrativo, n. 193, p. 384, Rio de Janeiro: Renovar, jul/set. 1993. 
Reforma das S.A. e do mercado de capitais. Rio de Janeiro: Renovar, 1997.

. Responsabilidade civil dos administradores da sociedade anônima, in: Escola de Magistratura do Estado do Rio de Janeiro: sociedade anônima. São Paulo: IBCB, 1993. p. 255.

Temas de direito societário. Rio de Janeiro: Renovar, 2005.

; GALL, Ariadna B.; HENRIQUES, Marcus de Freitas; e PARENTE, Flávia. Mercado de capitais: regime jurídico. 2. ed. Rio de Janeiro: Renovar, 2008.

FABRETTI, Láudio Camargo. Incorporação, fusão, cisão e outros eventos societários tratamento jurídico, tributário e contábil. São Paulo: Atlas, 2001.

FERRI, Giuseppe. Le società. Torino: Torinese, 1971.

FONSECA, Priscilla Maria Pereira Corrêa da. Dissolução parcial, retirada e exclusão de sócio. São Paulo: Atlas, 2002.

; SZTAJN, Rachel. Código civil comentado (artigos 887 a 926 a 1.195): direito de empresa. coord. Álvaro Villaça Azevedo. São Paulo: Atlas, 2008.

FORGIONI, Paula Andrea. A evolução do direito comercial brasileiro: da mercancia ao mercado. São Paulo: RT, 2009.

A interpretação dos negócios empresariais no novo Código Civil. Revista de Direito Mercantil, Industrial, Econômico e Financeiro, ano XLII, n. 130. São Paulo: Malheiros, abr./jun. 2003.

Teoria geral dos contratos empresariais. São Paulo: Revista dos Tribunais, 2009.

FRANÇA, Erasmo Valladão Azevedo e Novaes. Conflito de interesses nas assembleias de S.A. São Paulo: Malheiros, 1993. 
- Temas de direito societário, falimentar e teoria da empresa. São Paulo: Malheiros, 2009.

(org.). Direito societário contemporâneo I. São Paulo: Quartier Latin, 2009.

Invalidade de deliberações conexas de companhia. Revista de Direito Mercantil Industrial, Econômico e Financeiro, ano XLVI, n. 145, p. 255-269. São Paulo: Malheiros, jan./mar. 2007.

FRANÇA, Rubens Limongi. Enciclopédia Saraiva do direito, v. 9. São Paulo: Saraiva, 1978.

FRONTINI, Paulo Salvador. Responsabilidade dos administradores em face da nova lei das sociedades por ações. Revista de Direito Mercantil, Industrial Econômico Financeiro, ano XVI, n.26, p. 35-49. São Paulo: RT, 1977.

GALGANO, Francesco. Diritto commerciale - Le società. 4. ed. Bologna: Zanichelli, 1992.

; GENCHINI, Riccardo. Il nuovo diritto societário, t. 1. Padova: CEDAM, 2006, p. 1004-1005.

GILSON, Ronald J.; BLACK, Bernard S. The law and finance of corporate acquisitions. 2nd ed. New York: Foundation Press, 2003.

GAO - United States General Accounting Office. Report to the Senate Committee on Banking, Housing, and Urban Affairs and the House Committee on Financial Services. Public Accounting Firms: Required Study on the Potential Effects of Mandatory Audit Firm Rotation. Nov. 2003. Disponível em: 〈http://www.gao.gov/new.items/d04216.pdf〉. Acesso em: 5 jan. 2012. 
GARRIGUES, Joaquin; URÍA, Rodrigo. Comentario a la ley de sociedades anônimas, t. 1. Madrid: Instituto de Estudios Politicos, 1952.

; __ Comentario a la ley de sociedades anônimas, t. 2. Madrid: Instituto de Estudios Politicos, 1952.

GILSON, Ronald J.; BLACK, Bernard S. The law and finance of corporate acquisitions. $2^{\text {nd }}$. ed. New York: The Foundation Press, 1995.

GOMES, Orlando. Obrigações. 7. ed. Rio de Janeiro: Forense, 1984.

GONÇALVES NETO, Alfredo de Assis. A fusão, a incorporação e a cisão na lei de sociedade por ações. Revista de Direito Mercantil Industrial, Econômico e Financeiro, n. XXIII, v. 15, p. 71-90. São Paulo: RT, 1976.

GRAU, Eros Roberto. A ordem econômica na Constituição de 1988. 14. ed. rev. e at. São Paulo: Malheiros, 1998.

GUERREIRO, José Alexandre Tavares. Conflitos de interesse entre sociedade controladora e controlada e entre coligadas, no exercício do voto em assembleias gerais e reuniões sociais. Revista de Direito Mercantil Industrial, Econômico e Financeiro, ano XXII, n. 51, p. 29-32. São Paulo: RT, abr./jun. 1983.

- Direito de retirada: um limite ao princípio majoritário na sociedade anônima. Revista de Direito Mercantil Industrial, Econômico e Financeiro, ano XLVIII, n. 151/152, p. 12-21. São Paulo: Malheiros, 2009.

Sobre a conferência de bens. Revista de Direito Mercantil, Industrial, Econômico e Financeiro, ano XXI, n. 48, p. 16-24. São Paulo: RT, out./dez. 1982.

—. Sociologia do poder na sociedade anônima. Revista de Direito Mercantil Industrial, Econômico e Financeiro, ano XXIX, n. 77, p. 50-56. São Paulo: RT, jan/mar. 1990. 
; TEIXEIRA, Egberto Lacerda. Das sociedades anônimas no direito brasileiro, v.

1. São Paulo: Bushatsky, 1979.

_ _ Das sociedades anônimas no direito brasileiro, v. 2. São Paulo: Bushatsky, 1979.

HAUSER, Karl. O papel do mercado de capitais em uma economia de mercado. Revista Brasileira de Mercado de Capitais, v. 1, n. 3, São Paulo, 1975.

HENRIQUES, Vitor dos Santos. Exceções à regra de divulgação de informações relevantes por companhias abertas no direito brasileiro. Revista de Direito Bancário e do Mercado de Capitais, n. 50, p. 357-367. São Paulo: RT, 2010.

ICAEW - Institute of Chartered Accountants of England and Wales. Mandatory rotation of audit firms. July $2002 . \quad$ Disponível em:

<http://www.icaew.com/ /media/Files/Library/collections/ICAEW\%20archive/mandatory-

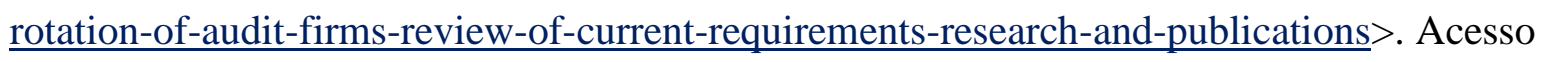
em: 5 jan. 2012.

INSTITUTE OF MANAGEMENT ACCOUNTANTS. Statements on management accounting: objectives of management accounting. New York, 1982.

IUDÍCIBUS, Sérgio de (et. al.). (FIPECAFI) Manual de contabilidade societária da Fundação Instituto de Pesquisas Contábeis, Atuariais e Financeiras. São Paulo: Atlas, 2010.

KLEIN, William A.; COFFEE JR., John C.; PARTNOY, Frank. Business organization and finance-legal and economic principles. New York: Foundation Press, 2010.

KRAAKMAN, Reinier et al. The anatomy of corporate law: a comparative and functional approach. New York: Oxford University Press, 2006. 
LAMY FILHO, Alfredo. Temas de S.A. - exposições e pareceres. Rio de Janeiro: Renovar, 2007.

; PEDREIRA, José Luiz Bulhões (coord.). Direito das companhias, v. 1. Rio de Janeiro: Forense, 2009.

; __ José Luiz Bulhões (coord.). Direito das companhias, v. 2. Rio de Janeiro:

Forense, 2009.

; __ A lei das S.A.: (pressupostos, elaboração, aplicação). 3. ed. Rio de Janeiro: Editora Renovar, 1997.

; __ A nova Lei das S.A., parte III, pareceres. 2. ed. Rio de Janeiro: Renovar, 1996. v. 2.

LISBOA, Lázaro Plácido. Ética geral e profissional em contabilidade. 2. ed. São Paulo: Atlas, 2011.

LEÃES, Luiz Gastão Paes de Barros. Incorporação de companhia controlada. Revista de Direito Mercantil Industrial, Econômico e Financeiro, ano XXXIII, n. 94, p. 87-96. São Paulo: Malheiros, abr./jun. 1994.

Pareceres, v. 1. São Paulo: Singular, 2004.

LEVY, Daniel de Andrade. Responsabilidade civil: de um direito dos danos a um direito das condutas lesivas. São Paulo: Atlas, 2012.

LINS, Eduardo dos Santos. Auditoria: uma abordagem prática com ênfase na auditoria externa. São Paulo: Atlas, 2011.

LOBO, Jorge. Direito de retirada nos casos de fusão, incorporação, cisão e participação em grupos de sociedades. Revista dos Tribunais, v. DCLXIV, p. 43-49. São Paulo: RT, 1991. 
Proteção à minoria acionária. Revista de Direito Mercantil Industrial, Econômico e Financeiro, ano XXXVI, n. 105, p. 25-36, São Paulo: Malheiros, jan./mar. 1997.

Reforma da lei das sociedades anônimas. Rio de Janeiro: Forense, 2002.

LONGO, Claudio Gonçalo. (FIPECAFI) Manual de auditoria e revisão de demonstrações financeiras. 2. ed. São Paulo: Atlas, 2011.

LUCENA, José Waldecy. Das sociedades anônimas - comentários à lei (arts. 121 a 188), v. 2. Rio de Janeiro: Renovar, 2009.

MACHADO, Rubens Approbato. Sociedade por ações - Incorporação, fusão e cisão Direito de retirada. Revista de Direito Mercantil Industrial, Econômico e Financeiro, ano. XXX, n. 82, p. 46-61, São Paulo: Malheiros, 1991.

MARTINS, Eliseu (org.). Avaliação de empresas: da mensuração contábil à econômica. 1. ed. 7. reimp. São Paulo: Atlas, 2011.

Avaliação de empresas: da mensuração contábil à econômica. Caderno de Estudos FIPECAFI, n. XXIV, v. 13, jul./dez. 2000, p. 28-37.

MATIAS, Alberto Borges (et. al.). Análise financeira fundamentalista de empresas. São Paulo: Atlas, 2009.

MUNIZ, Ian; CASTELO BRANCO, Adriano. Fusões e aquisições: aspectos fiscais e societários. São Paulo: Quartier Latin, 2007.

NERY, Sandra de Medeiros. Preço de emissão das ações no aumento de capital da companhia - art. 170 da lei das Sociedades por ações (alterações introduzidas pela Lei 9.457/97. Revista de Direito Mercantil, Industrial, Econômico e Financeiro, ano XXXVII, n.115, p. 221-238. São Paulo: Malheiros, jul./set. 1999. 
NEVES, Maria Cecília de Castro. Incorporação de sociedade com patrimônio líquido negativo. Revista Forense, v. CCCXLV, p.103, São Paulo, jan/mar. 1999.

O'KELlEY, Charles R. T.; e THOMPSON, Robert, B. Corporation and other business associations: cases and materials. 3rd. ed. Nova York: Aspen Publishers, 1999.

OLIVEIRA, Alexandre Queiroz de; SANTOS, Neusa Maria Bastos Fernandes dos. Rodízio de firmas de auditoria: a experiência brasileira e as conclusões do mercado. Revista Contabilidade \& Finanças, v. XVII, n.45, São Paulo, set./dez. 2007.

PARENTE, Norma Jonssen. O direito de recesso na incorporação, fusão ou cisão de sociedades. Revista de Direito Mercantil Industrial, Econômico e Financeiro, ano XXXIV, n. 97, p. 67-75. São Paulo: Malheiros, jan./mar. 1995.

Limites da responsabilidade dos administradores pela indenização de prejuízos. Revista de Direito Bancário, e do Mercado de Capitais, n. XXXI, p.33, São Paulo: RT, jan./mar. 2006.

PENINO, Charles J.; SCHIFF, Jonathan B. The emerging authority of statements of management accounting. The journal of applied business research, v. 7, n. 1, 1990.

PENTEADO, Mauro Bardawil, The efficacy of intra-corporate approvals in negotiated mergers between controlling shareholder and its corporation under delaware and Brazilian law, Revista de Direito Mercantil Industrial, Econômico e Financeiro, ano XLV, n. 143, p. 76-105. São Paulo: Malheiros, jul./set. 2006.

PEREIRA, Alexandre Demetrius. Auditoria das demonstrações contábeis: uma abordagem jurídica e contábil. São Paulo: Atlas, 2011.

PEREIRA, Caio Mario da Silva. Responsabilidade civil. Rio de Janeiro: Forense, 1989. 
PINTO, Nelson Luiz. Responsabilidade civil - parecer de auditores - obrigações de meio e de resultado - dever de indenizar. Revista dos Tribunais, v. 716, p. 138. São Paulo: RT, jun. 1995.

PONTES DE MIRANDA, Francisco Cavalcanti. Tratado de direito privado, t. 7, atualizada por Vilson Rodrigues Alves. Rio de Janeiro: Bookseller, 2000.

PONTES DE MIRANDA, Francisco Cavalcanti. Tratado de direito privado, t. 1, at. por Judith Martins Costa [et. al.]. São Paulo: RT, 2012.

PRADO, Roberta Nioac (Org.). Reorganizações empresariais: aspectos societários e tributários. 1. ed. Sao Paulo: Saraiva, 2011.

PROENÇA, José Marcelo Martins. Insider Trading - Regime Jurídico de Informações Privilegiadas no Mercado de Capitais. São Paulo: Quartier Latin, 2005.

ROLIM, João Dácio; FONSECA, Frederico Almeida. Reorganização societária e planejamento fiscal. O ágio de investimentos e o uso de "empresas-veículo" (conduit companies). Revista Dialética de Direito Tributário, São Paulo, n. 158, p. 61, nov/2008.

RICARDINO, Álvaro; CARVALHO, L. Nelson. Breve retrospectiva do desenvolvimento das atividades de auditoria no Brasil. Revista Contabilidade \& Finanças, São Paulo, v. XV, n. 35, mai./ago. 2004.

RIPERT, Georges. Traité élémentaire de droit commercial. Paris: LGDJ, 1974.

SADDI, Jairo (org.). Fusões e aquisições: aspectos jurídicos e econômicos. São Paulo: IOB, 2002.

SANTOS, Ariovaldo dos; GRATERON, Ivan Ricardo Guevara. Contabilidade criativa e responsabilidade dos auditores. Revista Contabilidade \& Finanças, São Paulo, v. XIV, n.32, mai./ago. 2003. 
SAlOMÃO FILHO, Calixto. O Novo Direito Societário. 3. ed. São Paulo: Malheiros, 2002.

SARAIVA, Luciana de Pontes. Governança Corporativa e auditores independentes: uma visão de Sarbanes-Oxley Act e da Regulamentação da Comissão de Valores Mobiliários, in CANTIDIANO, Luiz Leonardo. Governança corporativa: empresas transparentes na sociedade de capitais. São Paulo: Lazuli Editora, 2004.

SIMON, Herbert A. A behavioral model of rational choice. The Quarterly Journal of Economics, v. LXIX, n. 1, fev. 1955, p. 99-118.

SILVA, Adriano Gomes da; ROBLES JUNIOR, Antonio. Os impactos na atividade de auditoria independente com a introdução da lei Sarbanes-Oxley. Revista Contabilidade \& Finanças, São Paulo, v. XIX, n.48, set./dez. 2008.

SILVA, José Afonso da. Comentário contextual à Constituição. 2. ed. São Paulo: Malheiros, 2006.

STOCO, Rui. Tratado de responsabilidade civil: doutrina e jurisprudência. 8. ed. rev. e at. São Paulo: RT, 2011.

TOLEDO, Paulo F.C. Salles. O conselho de administração na sociedade anônima estrutura, funções e poderes, responsabilidade dos administradores de acordo com a nova lei das S.A. São Paulo: Atlas, 1997.

VALVERDE, Trajano de Miranda. Sociedades por ações: comentários ao Decreto-Lei 2.627, de 26 de setembro de 1940, v. 1. Rio de Janeiro: Forense, 1959.

Sociedades por ações: comentários ao Decreto-Lei 2.627, de 26 de setembro de 1940 ,v. 2. Rio de Janeiro: Forense, 1959. 
VERÇOSA, Haroldo Malheiros Duclerc. Conselho Monetário Nacional. Competência reguladora. Auditorias independentes. Revista de Direito Mercantil Industrial, Econômico e Financeiro, ano XL, n. 124, p. 208-213. São Paulo, Malheiros, out./dez. 2001.

WARDE JR., Walfrido Jorge (org.). Fusão, cisão, incorporação e temas correlatos. São Paulo: Quartier Latin, 2009. 